
Digitized by the Internet Archive in 2011 with funding from

LYRASIS members and Sloan Foundation 
$7-\operatorname{Ag} 8: 3 \cdot 334$

U. S. Department of Agricultwire

Office of Experinent istatious

Bulletin 334

Litrary.

February, 1932

\title{
POTASH REQUIREMENTS OF THE TOBACCO CROP
}

\author{
P. J. ANDERSON, T. R. SWANBACK \\ AND O. E. STREET
}

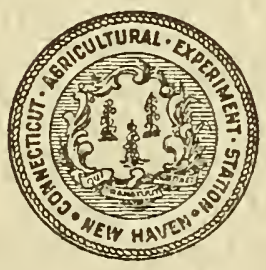

Cunnertirut

Agrioultural Expariment Statiun

Now YHarn 



\title{
POTASH REQUIREMENTS OF THE TOBACCO CROP
}

\author{
P. J. ANDERSON, T. R. SWANBACK \\ AND O. E. STREET
}

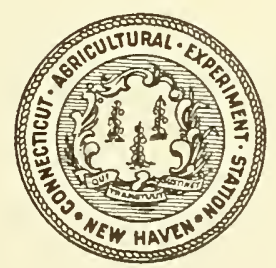

(Tamertirat

\section{Anrinultural Extroriment}

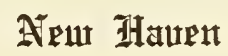


CONNECTICUT AGRICULTURAL EXPERIMENT STATION

\section{BOARD OF CONTROL}

His Excellency, Governor Wilbur L. Cross, ex-officio, President

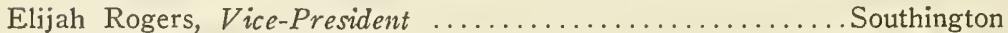
George A. Hopson, Secretary ............................... Carmel William L. Slate, Director and Treasurer .................. New Haven

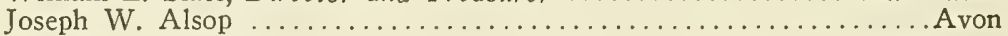

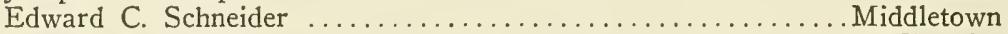

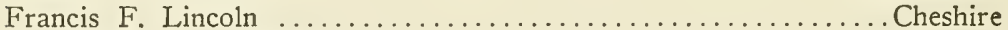
S. McLean Buckingham ........................................

\section{STAFF}

Administration.

Analytical Chemistry.

Biochemistry,

Botany.

Entomology.

Forestry.

Plant Breeding.

Soils.

Tobacco Substation at Windsor.
William L. Slate, B.Sc., Director and Treasurer.

Miss L. M. BRAUtLeCHT, Bookkeeper and Librarian.

Miss DoRothy AMRINE, B.LITT., Editor.

G. E. GrahaM, In Charge of Buildings and Grounds.

E. M. BaILeY, Рн.D., Chemist in Charge.

C. E. SHEPARD

OWEN L. NOLAN

HARRY J. FISHER, PH.D. Assistant Chemists.

W. T. MATHIS

DAVID C. WALDEN, B.S

Frank C. Sheldon, Laboratory Assistant.

V. L. Churchill, Sampling Agent.

Mrs. A. B. Vosburgh, Secretary.

H. B. VICKERY, PH.D., Biochemist in Charge

Lafayette B. Mendel, Ph.D., (Yale University) Research Associate.

George W. Pucher, Ph.D., Assistant Biochemist.

G. P. Clinton, Sc.D., Botanist in Charge.

E. M. STODdard, B.S., Pomologist.

Miss Florence A. McCormick, Ph.D., Pathologist.

A. A. Dunlap, PH.D., Assistant Mycologist.

A. D. McDon NelL, General Assistant.

Mrs. W. W. Kelsey, Secretary.

W. E. Britton, Pr.D., D.Sc., Entomologist in Charge, State Entomologist.

B. H. WALDEN, B.AgR.

M. P. ZAPPE, B.S.

Philip GarMan, PH.D.

ROGER B. FRIEND PH.D.

NEELY TURNER, M.A.

JoHN T. Ashworth, Deputy in Charge of Gipsy Moth Control.

R. C. BOTSFORD, Deputy in Charge of Mosquito Elimination.

J. P. Johnson, B.S., Deputy in Charge of Asiatic and Japanese Beetle Quarantines.

Mrs. Gladys Brooke, B.A., Secretary.

Walter O. Filley, Forester in Charge.

H. W. Hicock, M.F., Assistant Forester.

J. E. RILEY, JR., M.F., In Charge of Blister Rust Control.

Miss Pauline A. Mercenan, Secretary.

Donald F. Jones, Sc.D., Geneticist in Charge.

W. RalPH SingLeton, Sc.D., A ssistant Geneticist.

LaWrence C. Curtis, B.S., Assistant.

Mrs. Catherine R. MiLler, M.A., Secretary.

M. F. Morgan, M.S., Agronomist in Charge.

H. G. M. J ACoBson, M.S., Assistant Agronomist.

Herbert A. Lunt, Ph.D., A ssistant in Forest Soils.

DwIGH B. Downs, General Assistant.

Paul J. Anderson, Ph.D., Pathologist in Charge.

T. R. SWanback, M.S., Agronomist.

O. E. STREeT, M.S., Plant Physiologist.

Miss DoRothy Lenard, Secretary. 


\section{CONTENTS}

Page

The Functions of Potassium in Plant Nutrition ............. 137

Resistance to disease .......................... 139

Symptoms of Potash Deficiency in the Green Tobacco Plant ... 140

Percentage of Potash in Cured Leaves ..................... 142

Effect of quantity of fertilizer potash ................. 142

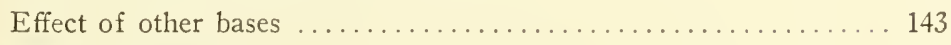

Effect of season ............................... 147

Native Potassium in the Soll . . . . . . . . . . . . . . . . . . . 147

Methods of Increasing the Availability of Native Potash ....... 149

Leaching of Potash from the Soll . . . . . . . . . . . . . . . 152

Potassium in the Plant . . . . . . . . . . . . . . . . . . . . . 157

Compounds of potassium in the plant . . . . . . . . . . . 159

Role of potash salts in absorption of water by cured leaves ...... 161

Rate of Intake by the Plant . . . . . . . . . . . . . . . . . 162

Role of Potash in Combustion of the Cigar .................. 164

How Much Potash Should Be Used Axnually in the Fertilizer . . 173

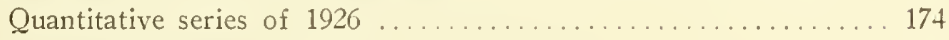

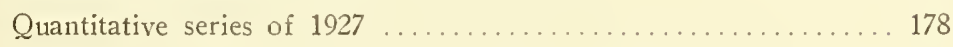

Influence of the quantity on the fire-holding capacity .......... 181

Effect of the quantity on the amount of potash, calcium and mag-

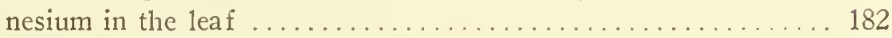

Discussion of results of field tests . . . . . . . . . . . . . 184

Comparison of Potash-Containing Fertilizer Materials ....... 185

Fertilizer materials containing potash ................ 185

Field tests of potash carriers . . . . . . . . . . . . . . . 190

Series I. Comparison of sulfate, carbonate and nitrate of potash.

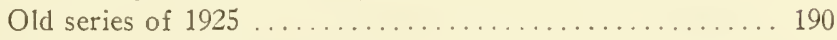

Series II. Comparison of sulfate, carbonate and nitrate of potash. New series of $1927 \ldots \ldots \ldots \ldots \ldots \ldots \ldots \ldots$

Series III. Comparison of sulfate of potash-magnesia with high

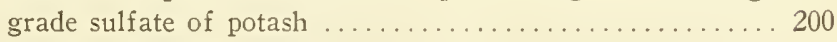

Series IV. Tobacco stems compared with mineral carriers of

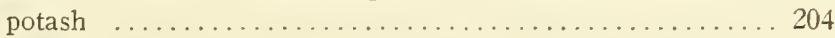

Series V. Comparison of cottonhull ashes with other materials . 207

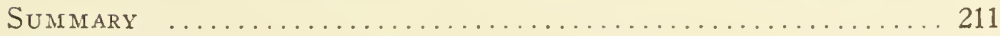

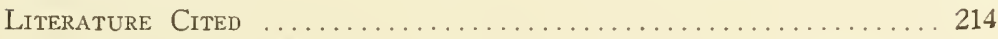





\title{
POTASH REQUIREMENTS OF THE TOBACCO CROP
}

\author{
P. J. Annerson, T. R. Swanback, and O. E. Street
}

Tobacco as grown in New England takes from the soil more pounds per acre of potash than any other plant nutrient. Furthermore, no other important crop in this region, with the possible exception of alfalfa, removes annually so large an amount. Table 1 shows how Connecticut tobacco compares in this respect with some other common crops. Not only is potash essential to the growth and health of the plant but it also has a particular function in tobacco, that of promoting the burn of the cigar, in which role it is more important than any other element.

Field experiments comparing different amounts and sources of potash in the fertilizer were begun soon after the Tobacco Substation was established in 1921. These have been enlarged and continued each year. Laboratory and greenhouse studies have been carried on to supplement the field work. Progress reports have been included in the Annual Reports of the Tobacco Substation, but no complete statement has been published.

The purpose of this Bulletin is to bring together and discuss for the general reader, as well as the scientist, all of these investigations in the light of our present knowledge. For this reason there is included pertinent material from other sources, and an attempt has been made to present as complete a discussion as possible of the relation of this important element, potassium ${ }^{1}$, to cigar leaf tobacco.

\section{FUNCTIONS OF POTASSIUM IN PLANT NUTRITION}

Potassium is absolutely essential to plant growth and cannot be replaced entirely by any other element. Although exact knowledge of all its functions is lacking, most plant physiologists agree that the specific and all-important role of potassium in plants is its action as an activating agent (catalist) in the synthesis of carbohydrates (starch, sugar and cellulose). Without potassium there would be no photosynthesis, and green plants could not exist in the absence of the simple carbon-containing foods (products of photosynthesis), from which all the organs of the plant largely are

\footnotetext{
${ }^{2}$ Both terms, potash and potassium, will be used in this Bulletin, depending on the context. In discussing fertilizers, the term potash, the oxide of potassium $\left(\mathrm{K}_{2} \mathrm{O}\right)$, is commonly used, whereas the term potassium, the element $(K)$, is more often used by plant physiologists. To convert pounds or percentage of potassium to potash, multiply by 1.2046 . To convert figures for potash to potassium, multiply by .8301 .
} 
elaborated. There is also considerable evidence that potassium has the same function in the synthesis of proteins. Cell division, or mitosis, does not occur in the absence of potassium, and in such a case, no cambium or other embryonic tissue can function, whereupon growth ceases, obviously because new protoplasm is lacking. Potassium, however, is not a constituent of protoplasm, cell walls,

Table 1. Potash Removed Annually by Various Crops ${ }^{1}$

\begin{tabular}{|c|c|c|}
\hline Crop & Yield per acre & $\begin{array}{l}\text { Lbs. } \\
\text { potash }\left(\mathrm{K}_{2} \mathrm{O}\right) \\
\text { removed per acre }\end{array}$ \\
\hline Alfalfa hay & 8 tons & 230 \\
\hline $\begin{array}{cc}\text { Tobacco leaves } \\
\text { Total }\end{array}$ & $\begin{array}{l}1800 \text { lbs. } \\
1200 \text { lbs. (dry weight) }\end{array}$ & $\begin{array}{r}108 \\
47 \\
155\end{array}$ \\
\hline Clover hay & 4 tons & 144 \\
\hline Potatoes & 300 bu. & 108 \\
\hline Timothy hay & 3 tons & 85 \\
\hline $\begin{array}{c}\text { Corn grain } \\
\text { stover } \\
\text { Total }\end{array}$ & $\begin{aligned} 100 \text { bu. } \\
3 \text { tons }\end{aligned}$ & $\begin{array}{l}23 \\
62 \\
85\end{array}$ \\
\hline $\begin{array}{l}\text { Oats grain } \\
\text { straw } \\
\text { Total }\end{array}$ & $\begin{array}{l}100 \mathrm{bu} . \\
2 \mathrm{I} / 2 \text { tons }\end{array}$ & $\begin{array}{l}19 \\
62 \\
81\end{array}$ \\
\hline $\begin{array}{c}\text { Wheat grain } \\
\text { straw } \\
\text { Total }\end{array}$ & $\begin{array}{l}50 \mathrm{bu} . \\
2 \mathrm{I} / 2 \text { tons }\end{array}$ & $\begin{array}{l}16 \\
54 \\
70\end{array}$ \\
\hline $\begin{array}{l}\text { Apples (fruit) } \\
\text { wood growth } \\
\text { Total }\end{array}$ & 600 bu. & $\begin{array}{r}68 \\
6 \\
74\end{array}$ \\
\hline
\end{tabular}

or any essential solids in the plant. It is present only in solution in the cell sap, from which it may, however, infiltrate or even occur as a physiological precipitate within the plant tissue $(55) .^{2}$

1 These figures, with the exception of those for tobacco, are taken from Hopkins' Soil Fertility and Permanent Agriculture, page 154, and are for maximum crops, much above the average. The figure for tobacco ( 1800 pounds) is above the average, but by no means a maximum. The figure for percentage of potash in stalks is taken from Station Bulletin 180 , page 10. Hopkins' figure for 8 tons of alfalfa hay to the acre is entirely too high for Connecticut yields.

2Figures in parentheses refer to "Literature Cited" on p. 214 of this bulletin. When two numbers separated by a colon are used, the second designates the page of the publication cited. 
In addition to its specific function as an activating agent, potassium has certain general functions, that is, it accomplishes, or helps to accomplish, certain purposes that may also be accomplished by other elements. For example, potassium serves as a carrier in the absorption of nitrates and other anions through the root hairs and in their translocation throughout the plant. An adequate supply of potassium makes the tobacco plant more resistant to drought. We have frequently observed that in hot dry weather the tobacco on the low-potash fertilizer plots is the first to wilt $(5: 153$, and $6: 207)$.

\section{Resistance to Disease}

The statement is sometimes made that potash makes plants more resistant to disease. Thus Hall (37) says: "There is abundant experimental evidence to show that potash makes the plant more resistant to the attack of fungoid diseases." This conclusion was supported by his observations on beet leaf spot (Uromyces betae), wheat rust, and grass diseases on the fertilizer experimental fields at Rothamsted.

Boening (17), after his investigations on tobacco wildfire in Germany, stated that resistance to wildfire is increased in the same degree in which the potash application is augmented and the nitrogen supply diminished.

Moss and others (60) write: "Under some conditions the use of potash seems to control partially several of the leaf-spot diseases, including wildfire and blackfire, especially when used at a liberal rate. When the weather conditions favor the development of leafspot diseases the physiological breakdown herein described resulting from potash deficiency probably allows the organisms causing certain leaf-spots to gain entrance into the plant tissue, and these hasten the breakdown of the leaf tissue. At any rate, it is known that potash in some way aids in maintaining the general vigor of the plant. On those plots which were fertilized with a mixture carrying heavy rates of ammonia with little or no potash the various leaf-spot troubles have been more prevalent, causing serious damage; but with more potash added to the fertilizer there has been much less damage from leaf-spot."

Tobacco plants deprived of a sufficient ration of potash exhibit certain abnormal symptoms (as described in a later paragraph) and to this extent they may be spoken of as diseased; or possibly lesions so produced may offer infection courts for disease organisms. Nevertheless it has not been adequately demonstrated that plants that have enough potassium to carry on their normal functions may be made more resistant to a specific disease organism through absorption of additional potassium. That an abundant supply of potash is not a protection against the wildfire disease, 
is demonstrated by severe epidemics of this disease in the Connecticut Valley, where the percentage of potash in the leaf is probably higher than that of any other tobacco in the world.

Some important roles that potassium plays in "casing" and in combustion of cigar leaf tobacco will be discussed in subsequent sections of this Bulletin.
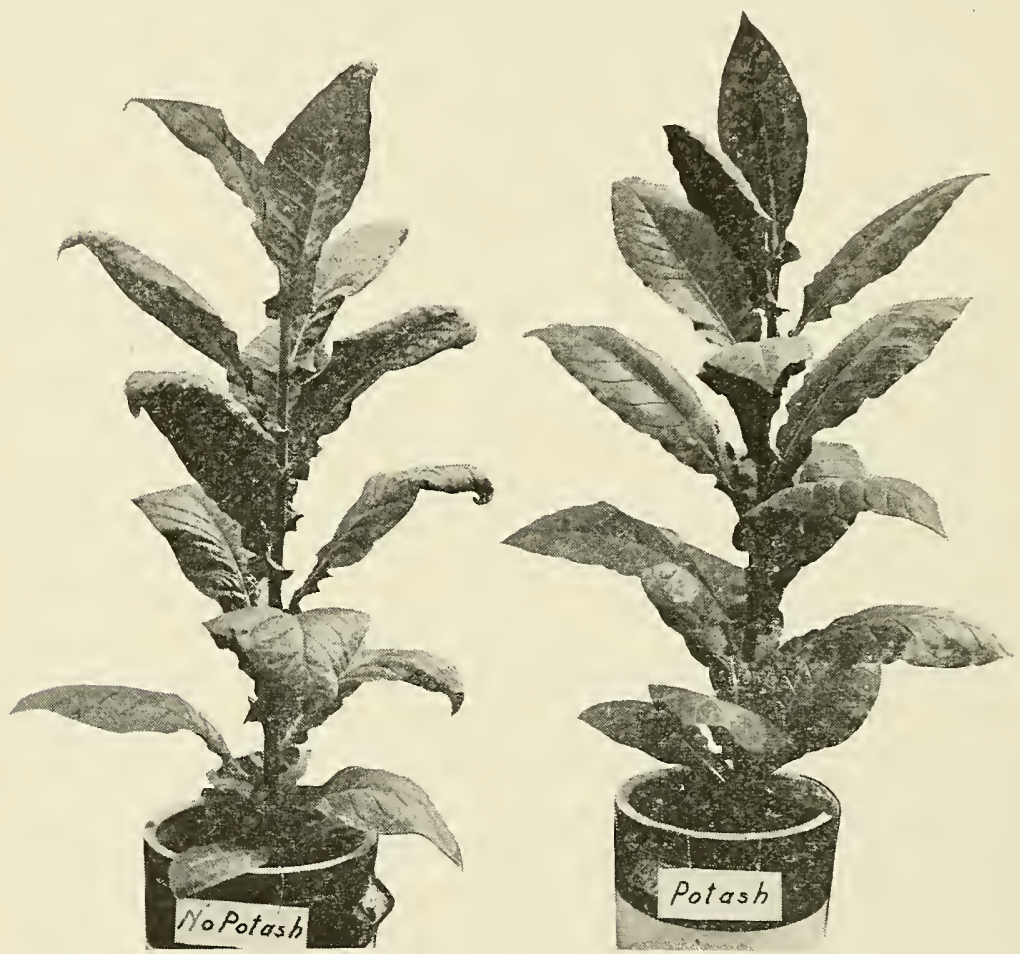

Figure 16. Normal plant (right) and plant showing potash starvation symptoms (left) on middle leaves. Note recurved tips and margins and hobbly leaves on latter.

\section{SYMPTOMS OF POTASH DEFICIENCY IN THE GREEN TOBACCO PLANT}

Tobacco plants that are not supplied with a sufficient amount of potassium for normal development exhibit certain symptoms that an experienced observer is able to recognize. These symptoms are characteristic of potash hunger, and readily distinguishable from those produced by a deficiency of any one of the other nutrient elements. 
In the earliest stages the potassium-starved leaves are mottled with yellow near the margins and tips, resembling somewhat the early stages of ripening. Soon the surface of the leaf becomes rough or puckered, "hobbly." Meanwhile the centers of the mottled areas have died and the margins and tips of the leaves are speckled with numerous small white spots. As the conditions grow worse, the margins of the leaves turn downward (Figure 17) giving them a rim-bound appearance. In severe cases the dead portions may coalesce and fall out or break and make the leaf appear ragged. On large leaves in the field, when potassium deficiency is not great,

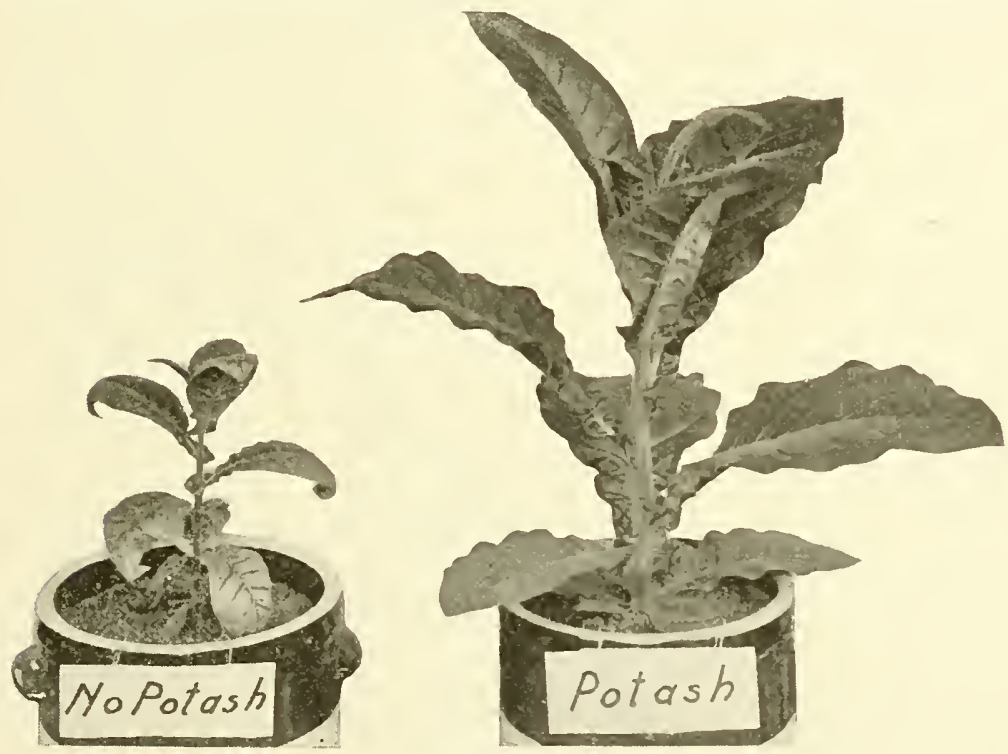

FIGURE 17. Effect of potash deficiency. Large plant on right had ail nutrients supplied. Small plant had all nutrients except potash. Note small size and rim-bound leaves with recurved tips. Plants of same age.

we have found the only symptoms to be a yellowing and sharp downward recurving of the leaf tips. The condition is illustrated in Figure 16.

Unlike magnesia hunger, the symptoms of potash hunger do not always appear first on the lower leaves. As shown in Figure 16, the lower leaves may be quite normal and the worst symptoms occur on the middle leaves. In very severe cases the plants are dwarfed (Figure 17) but we have not seen one severe enough to produce dwarfing in the fields of the Connecticut Valley. Stunting of growth is apparently not uncommon in tobacco districts farther south $(60)$. 


\section{PERCENTAGE OF POTASH IN CURED TOBACCO LEAVES}

Numerous analyses of cured tobacco from all tobacco growing sections of the world have been published. The potash percentages from a number of these are assembled in Table 2, which shows that the percentage of potash in the leaf varies widely, from 2.2 per cent to 8.5 per cent of the dry weight of the leaf. Samples from the same locality may differ considerably in this respect.

The percentage of potash in the tobacco leaf is not constant, but depends on (1) the amount of potash furnished in the fertilizer or naturally in the soil, (2) the relation of other elements, particularly the bases, and (3) the season. Whether there is a difference in the capacity of different tobacco varieties to absorb potash has not been demonstrated.

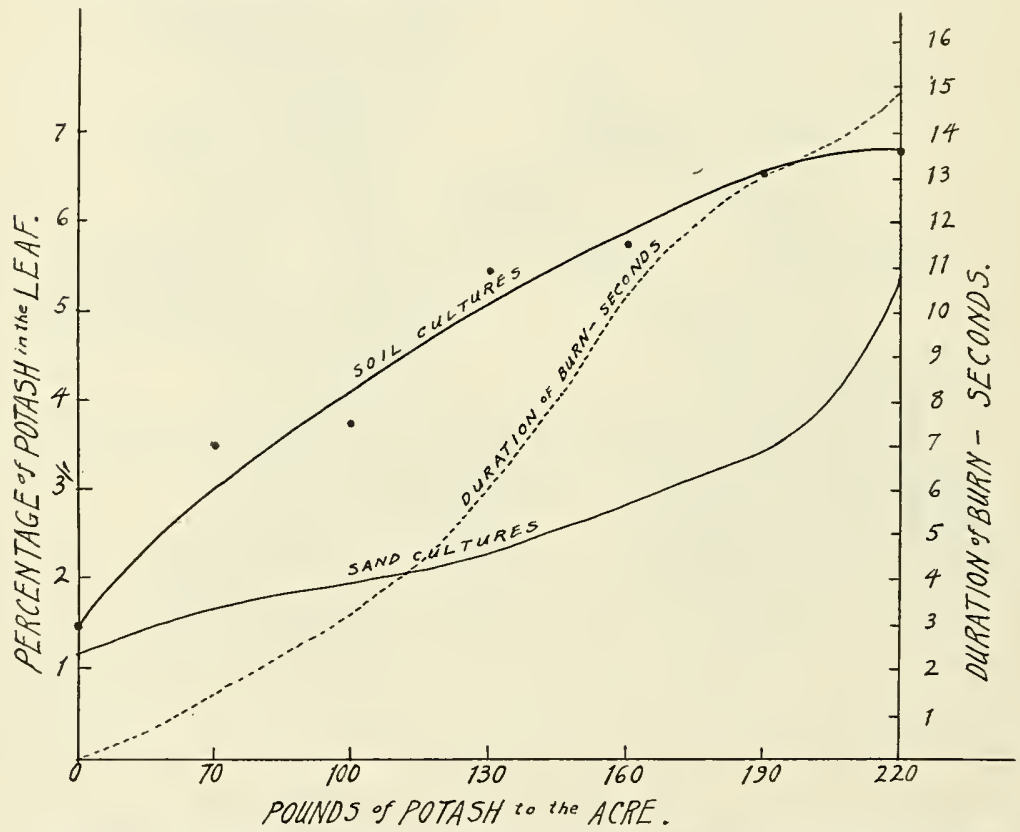

FIGURE 18. Graph showing correlation between quantity of fertilizer potash and the percentage of potash found in the leaves and the fire-holding capacity.

\section{Effect of Quantity of Fertilizer Potash}

In order to see how the percentage of potash in the leaf is dependent on the amount of potash applied to the soil, two series of greenhouse pot experiments were made in which increasing quantities of potash were applied. In the first series, the soil used was a good tobacco soil to which no fertilizer had been applied for 
five years, but which had been under continuous tobacco culture. In the second series, sand from a local pit was used. Analyses of the cured leaves, given in Table 3 , show that each increase of fertilizer potash gave a corresponding increase in the quantity of potash found in the leaf. This is graphically illustrated in Figure 18.

Otryganjew (65), growing tobacco plants in poor sandy soil in pots, was able to raise the potash content from .45 per cent to 7.22 per cent by increasing the quantity of potash applied to the soil. Table 21 shows how an increase in the quantity applied in the fertilizer under field conditions will increase the percentage of the leaf.

Pot experiments by Morgan (57) show that the percentage of potash can be reduced to as low as 1 per cent, but when the content falls to about 2 per cent the plants are abnormal. The 6 to 8 per cent commonly found in Connecticut tobacco is greatly in excess of the physiological needs of the plant, the surplus being due to "luxury consumption."

That the percentage of potash found in plants is primarily dependent on the quantity of potash applied to the soil in the fertilizer and may be raised or lowered very readily over a wide range has been demonstrated for a large number of plants (12).

\section{Effect of Other Bases}

The percentage of potassium in the plant is markedly affected by the percentage of the other mineral bases, particularly calcium and magnesium. The sum of these three dominant bases tends to be constant, that is, when one is increased, the sum of the others decreases in percentage somewhat proportionately. Schloesing (71), more than 70 years ago, called attention to the fact that in cured tobacco, the percentage of potash shows an inverse relationship to the percentage of calcium and magnesium. Ames and Boltz (1), working with Ohio tobacco, state that "the tobacco from limed plots contains less potassium." Graham and Carr (35) found the same effect. Anderson and Swanback (5:197) found a reduced percentage of potash in the tobacco from all limed plots as compared with adjacent unlimed plots. This was explained as due to the repressive effect of magnesia, which had been absorbed from the limed soil in larger amounts. Morgan (57:906) showed that calcium has the same repressive effect on potassium as has magnesium.

In order to study the extent of such potash repression, field plots at Windsor which had not grown tobacco in recent years were treated with increasing quantities of hydrated magnesian lime ( 57 per cent $\mathrm{CaO}$ and 29 per cent $\mathrm{MgO}$ ). The tobacco grown on them in 1930 was analyzed for the three bases. The results, pre- 


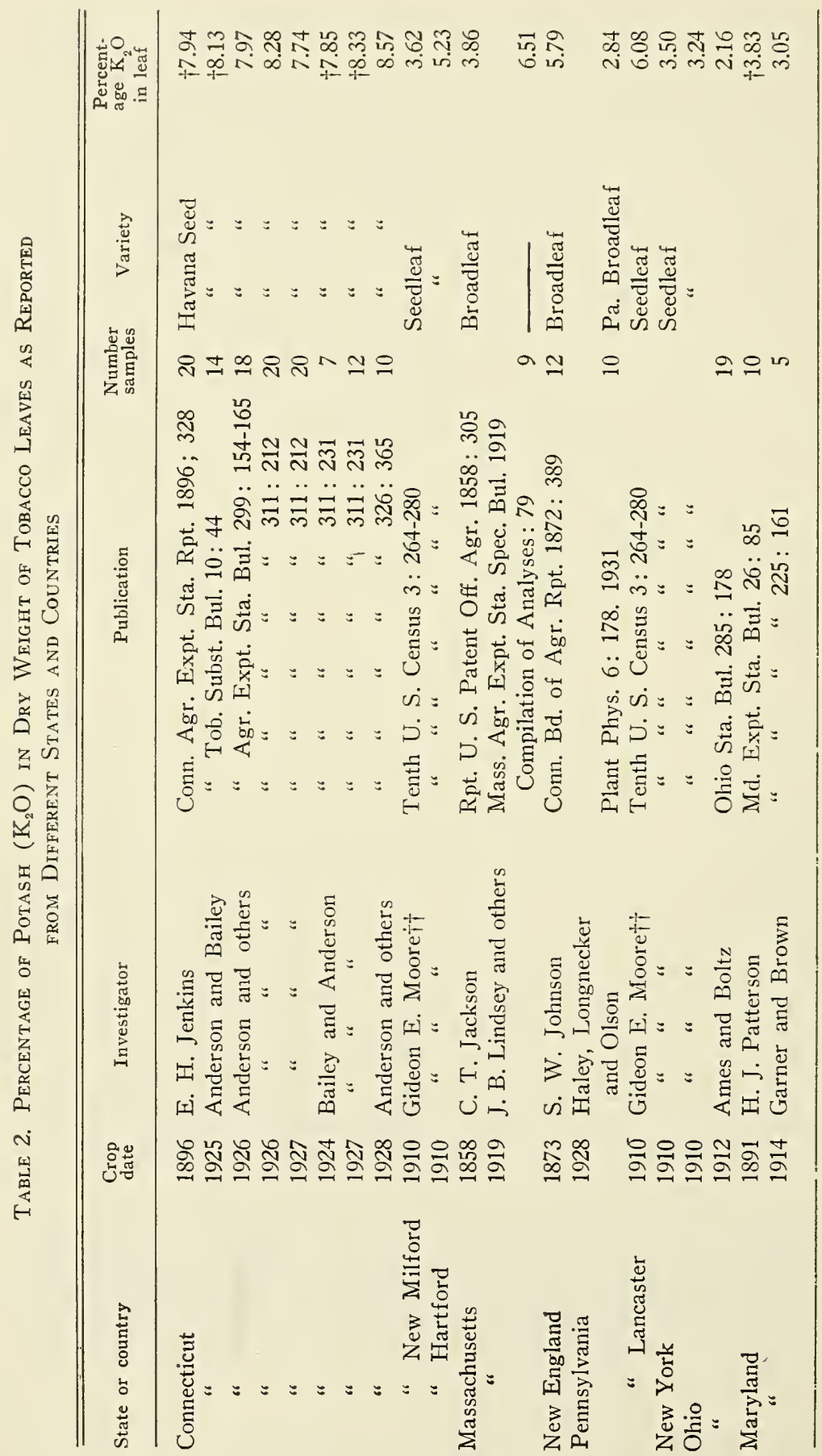




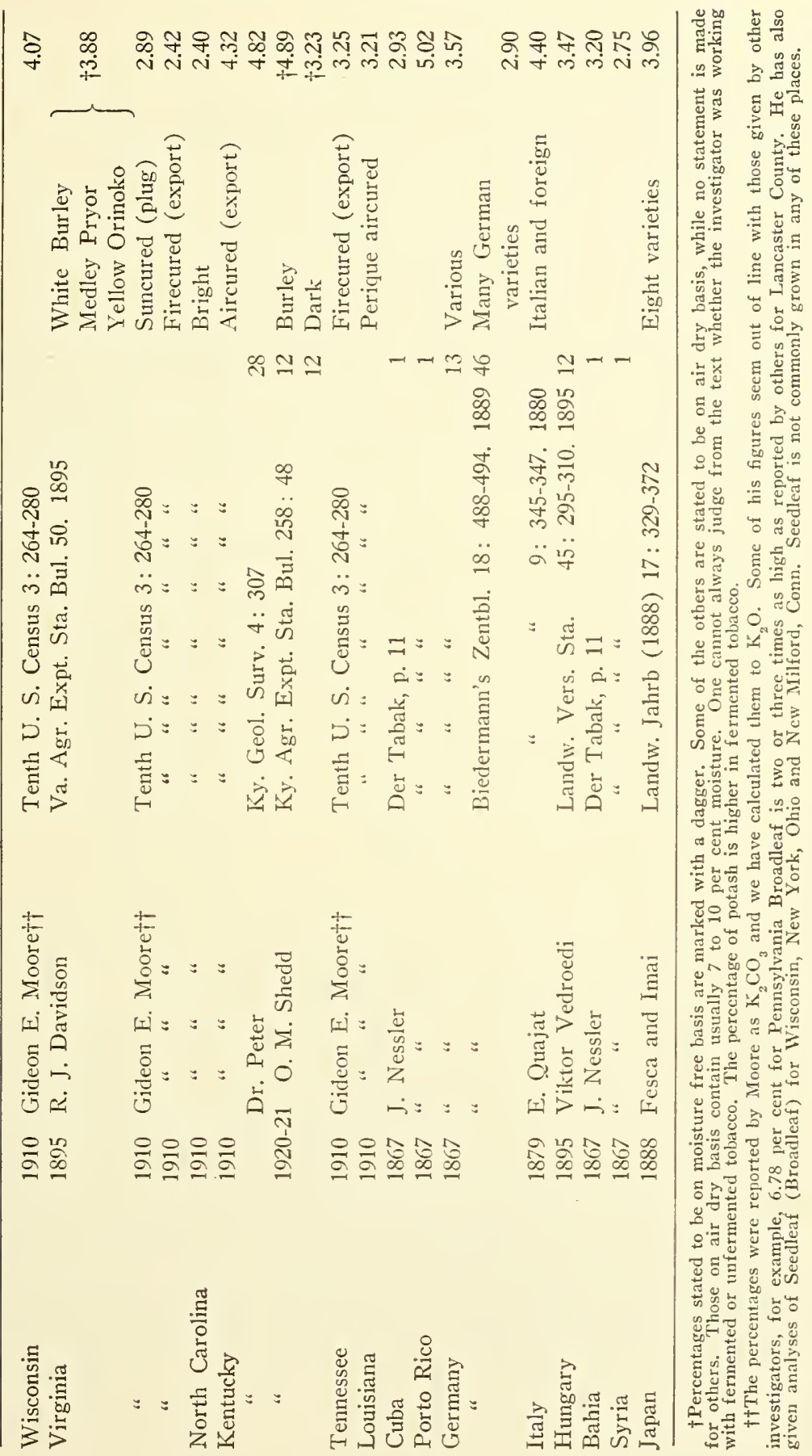


sented in Table 4, show that the magnesia was increased at the expense of both potash and calcium.

Such reciprocal repression among the three bases is not confined to tobacco. Gaither (31) and MacIntire (48) found that application of lime to wheat land reduced the percentage of potassium, as it increased the calcium, in the wheat. Others have observed the same effect on corn (45), alfalfa $(28,72)$, orange trees (69), grapevines (44), peas, (70) and other plants (56). This interrelation of bases, which thus appears to be general in plants, may be explained as due to the substitution of one cation for another in the absorption of mineral compounds from the soil. MacIntire and his associates $(50,51,52)$ have shown by lysimeter experiments how the addition of calcium or magnesium, in the form of liming materials, to the soil depresses the potassium content of the leached water. When calcium ions are in great

Table 3. Relation of Quantity of Potash Applied to Soll to the Percentage Found in the Leaf. Pot Experiments

\begin{tabular}{c|c|c}
\hline $\begin{array}{c}\text { Pounds } \mathrm{K}_{2} \mathrm{O} \text { applied } \\
\text { per acre }\end{array}$ & \multicolumn{3}{|c}{ Percentage $\mathrm{K}_{2} \mathrm{O}$ in leaf when grown } \\
\cline { 2 - 3 } & Soil & Sand \\
\hline 0 & 1.48 & 1.16 \\
10 & 3.49 & 1.65 \\
100 & 3.74 & 1.97 \\
130 & 5.47 & 2.26 \\
160 & 5.75 & 2.90 \\
190 & 6.54 & 3.45 \\
220 & 6.78 & 5.36 \\
\hline
\end{tabular}

excess over potassium ions in the soil solution, and cations are required as "carriers" for a certain amount of nutrient anions, such as nitrates, it is natural to suppose that more calcium than potassium ions would be used, that is, the ratio of the absorbed cations would tend toward that which exists in the soil solution. Under field conditions such as we have in this state, a substitution of calcium or magnesium for potassium would not interfere with the normal development of the plant because potassium is absorbed in great excess of the plant's physiological needs. In field experiments on the Station farm, it has not been possible to produce acute symptoms of potash starvation except by heavy liming of some plots where all mineral potash fertilizers have been omitted for several years, a condition that would never occur on a tobacco farm. 


\section{Effect of the Season}

The potash content of the leaf is higher during seasons of heavy rainfall than during seasons of light rainfall. Analyses showing this relationship in Connecticut tobacco have been published by the writers $(6: 228)$ and for Pennsylvania tobacco by Haley, Nasset and Olson (36).

A reasonable explanation of the increased potash during a wet year is this: The most abundant base with which the soil colloids (or acidoids) are combined is calcium. When the soil is treated with a potash salt, the potassium ions displace the calcium ions in the colloidal complex. The calcium ions, thus brought into true solution in the soil water, will be readily absorbed by the tobacco roots during a dry year. During a wet year, however, the calcium salts will be leached out of the soil water and the plant will be forced to get more of its supply of cations from potash ions of the colloidal complex. Bartholomew and Jannsen (12:55), working with a number of crops, noted such seasonal variation in the percentage of potash but made no attempt to explain it.

Table 4. Effect of Magnesian Lime on Percentage of Calcium, Magnesium and Potassium in Tobacco. (Air Dry Basis on Unfermented Leaves)

\begin{tabular}{c|c|c|c}
\hline \hline \multirow{2}{*}{$\begin{array}{c}\text { Pounds magnesia applied } \\
\text { per acre }\end{array}$} & \multicolumn{3}{|c|}{ Percentage found in the cured leaves } \\
\cline { 2 - 4 } & $\mathrm{K}_{2} \mathrm{O}$ & $\mathrm{CaO}$ & $\mathrm{MgO}$ \\
\hline None & 4.83 & 6.75 & 1.32 \\
100 & 3.98 & 6.22 & 2.47 \\
200 & 3.12 & 5.63 & 3.13 \\
400 & 3.09 & 5.26 & 3.83 \\
600 & 2.40 & 4.95 & 4.59 \\
\hline
\end{tabular}

\section{NATIVE POTASSIUM IN THE SOIL}

The major (mineral) part of soil has been formed and is still being formed through disintegration or decomposition of the underlying rocks. Some of the minerals composing the original rock, and hence now present in the soil in various stages of disintegration, contain potassium in a highly insoluble form. The most common of these minerals are the feldspars (orthoclase and microcline, $\mathrm{KA} \mathrm{Si}_{3} \mathrm{O}_{8}$ ) and mica (muscovite and biotite, $\mathrm{K}, \mathrm{Mg}$, $\mathrm{Fe}, \mathrm{H}, \mathrm{A1}$-silicates). During the process of disintegration of the parent rock by physical processes into smaller particles, there is also a slow chemical breakdown of the complex potassium-containing compounds into simpler compounds that are soluble and thus available for absorption into the root hairs. Carbon dioxide 
in the soil solution plays an important role in this process as may be illustrated by the following chemical equation:

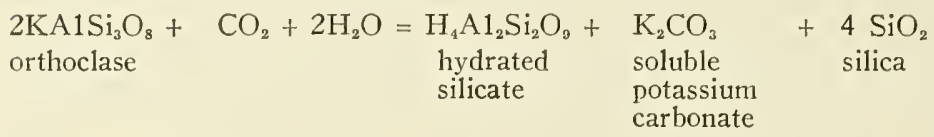

When in the process of physical disintegration, the mineral particles have become so small that they approach, but do not actually attain, a molecular size, they assume under ordinary soil conditions a jelly-like consistency which is characteristic of some colloids. The present conception of a soil colloid is that it consists of a relatively insoluble nucleus (acidoid) which functions as a large anion and is able to hold in a replaceable condition the cations, calcium, potassium, magnesium, and others. Although calcium is the most abundant cation in the soil colloidal complex, the latter also contains considerable potassium which is in a state easily made available for plant nutrition. Thus we may distinguish three different states in which potash is present in soil, (1) insoluble minerals, (2) colloidal combinations, and (3) water soluble compounds.

Only an extremely small part of the potassium remains in a water soluble form because of the soil's well-known capacity for absorbing potash. This may be demonstrated by adding to some soil a water solution of any of the common potash fertilizer materials such as sulfate, carbonate, or nitrate of potash. After the soil is saturated, it may be thoroughly leached by addition of excess of water. If the water that leaches through the soil is analyzed, it will be found to contain only very small amounts of potassium because most of it has been absorbed. The process of absorption consists of an exchange of bases between the potassium salt and the colloid, as may be expressed by the following equation in which $\mathrm{X}$ represents the colloidal acidoid:

\begin{tabular}{|c|c|c|c|c|}
\hline $\begin{array}{l}\mathrm{K}_{2} \mathrm{SO}_{4} \\
\text { potassium } \\
\text { sulfate }\end{array}$ & + & $\begin{array}{l}\qquad \mathrm{Ca} \mathrm{X} \\
\text { acidoid with } \\
\text { calcium base }\end{array}$ & & $\begin{array}{l}\mathrm{Ca} \mathrm{SO}_{4} \\
\text { calcium } \\
\text { sulfate }\end{array}$ \\
\hline
\end{tabular}

Although the potassium thus attached to the colloid is insoluble in water, it is nevertheless relatively available to the plant, probably being again brought into solution through the action of carbonic or other acids. Neutral salts may also displace it. It is spoken of as "replaceable" potash and its amount in a soil probably most nearly represents the capacity of that soil to supply the potash needs of any crop grown on it.

Connecticut soils, according to analyses by Morgan ( $57: 884$ ), contain 25,000 to 50,000 pounds of total potash to the acre in the tillable surface, or, enough to grow maximum crops for 100 years 
or more if it were available. Tests show, however, that on many soils less than 200 pounds of this amount are in an exchangeable condition, hence the necessity of annual applications of potash fertilizers.

From the above statements it is apparent that the soil potash is not stationary, but is in a constant state of change. The mineral potash is gradually changing into more soluble compounds and some of the soluble compounds are leached away into the lower layers or even into drainage water. Certain of the insoluble minerals are transformed to a colloidal condition and the colloids absorb the soluble compounds or at times liberate the potassium ions. It is even possible that some of the soil potash is being reverted into insoluble minerals (12).

This dynamic condition of the soil potash is the main reason why it is not possible by any chemical analysis yet devised to determine the capacity of a given soil to furnish potash for crop production. The plant appears to be able to extract from the soil water, soluble potash, replaceable potash, and even some of the so-called insoluble mineral potash $(29,8)$. Efforts to duplicate this capacity of the plant by chemical treatment of the soil in the laboratory have not yet been successful, but a determination of the replaceable potash (as by leaching with ammonium chloride) of a series of soils will give an indication of the relative capacity of these soils to supply potash to the plant.

\section{METHODS OF INCREASING THE AVAILABILITY OF NATIVE POTASH}

Since in Connecticut soils a great store of potash is always locked up around the roots, while the farmer must annually incur the expense of supplying his crop with commercial potash fertilizers in order that the plants will not suffer for lack of it, it is natural that agricultural scientists long ago should have directed their efforts to discover a method of liberating the native soil potash. Application of lime was for years advocated as a means to this end, but later research, as noted previously in this Bulletin, showed that lime not only did not liberate potash but that, on the contrary, it prevented its liberation.

Gypsum has been investigated in this role, but with rather contradictory results. Bradley in Oregon (18) concluded from his experiments that application of gypsum to the soil liberated potash. Shedd in Kentucky (73) had contradictory results, but some of the tests showed an increase in the potassium of crops grown after treatment of the soil with gypsum. Tressler (75) found that gypsum liberated potash in some soils but not in others. Briggs and Breazeale (19), on the contrary, concluded as a result of their experiments with wheat seedlings: "The availability to plants of 
potash in soils derived from orthoclase-bearing rocks is not increased by the addition of lime or gypsum. In some instances a marked depression of the solubility of the potash in the presence of gypsum was observed." Cubbon (23) concluded from laboratory tests: "Leaching various soils with saturated calcium sulfate solutions did not result in a marked liberation of potassium."

Analyses of tobacco grown on plots treated with different quantities of gypsum for two years at the Windsor Station lend some support to the belief that gypsum may assist in liberating potash

Table 5. Effect of Gypsum Application on Chemical Composition of the Tobacco. Crop of 1930. (Air Dry Basis on Unfermented Tobacco)

\begin{tabular}{c|c|c|c|c|c}
\hline \hline \multicolumn{2}{c|}{$\begin{array}{c}\text { Annual application } \\
\text { of gypsum, pounds } \\
\text { per acre }\end{array}$} & \multicolumn{4}{|c}{ Percentage of compounds found in the leaf } \\
\cline { 1 - 6 } 1929 & 1930 & $\mathrm{~K}_{2} \mathrm{O}$ & $\mathrm{CaO}$ & $\mathrm{MgO}$ & $\mathrm{SO}_{3}$ \\
\hline None & None & 5.55 & 5.40 & 1.71 & 1.13 \\
500 & 250 & 7.03 & 6.26 & 1.56 & 1.57 \\
1000 & 500 & 6.68 & 5.47 & 1.43 & 1.75 \\
5000 & 2500 & 6.16 & 6.69 & 1.43 & 2.19 \\
\hline
\end{tabular}

(Table 5). According to these results there has been more of an increase in the potash, than in calcium, by the use of gypsum. This was accompanied by a decrease in magnesia, as might have been anticipated. The increase in sulfur, indicated by these analyses is not desirable in tobacco because it reduces fire-holding capacity, which would likely offset any advantage obtained from the increase in potash.

Shedd (73) found that sulfur alone increased the availability of potash. The effect of sulfur is to increase the acidity of the soil, which is known to increase potash availability. Here again it might be anticipated that the sulfur content of the tobacco would be increased, but no analyses bearing on this point have been published.

There is some experimental evidence to show that sodium salts may increase the availability of potash. Thus Hall (37), speaking of the potash plots at Rothamsted, says: "Potash increased the crop in every case except where nitrate of soda had been used; the soda liberates so much potash from the soil that specific application of potassic manures is unnecessary."

On the contrary, de Turk (26), working with a number of potash-bearing native minerals, concluded as a result of his experiments: "The addition of soluble sodium salts to peat soil together with the minerals does not increase the yield of crop or the availability of the mineral potassium." 
Experiments at the Windsor Station indicate that the use of nitrate of soda may increase the absorption of potash by the crop. In the nitrogen field tests, four plots received the standard quantity of all nutrients for five years, but differed among themselves only in the source of the nitrogen, each receiving all its nitrogen supply from a single carrier. The nitrogen carrier of each and the percentage of potash found in the leaves grown on each plot in 1930 are shown in Table 6 . The highest percentage of potash was seen

Table 6. Effect of Nitrate of Soda on Absorption of Potash

\begin{tabular}{lc}
\hline $\begin{array}{c}\text { Carrier of nitrogen used in } \\
\text { fertilizer }\end{array}$ & $\begin{array}{c}\text { Percentage of potash in } \\
\text { leaves }\end{array}$ \\
\hline Nitrate of soda & 6.88 \\
Cottonseed meal & 5.62 \\
Sulfate of ammonia & 6.07 \\
Urea & 6.39 \\
\hline
\end{tabular}

to be in the tobacco where nitrate of soda was the only source of nitrogen.

When used in moderate amounts, sodium itself is not absorbed to any considerable extent by the plant. In another set of experiments, however, where increasing quantities of nitrate of soda were used, it was found that a point was finally reached where sodium was taken up in considerable quantities and at that point it had a repressive effect on the potash. Below that point, however, the potash content of the leaf was increased by application of nitrate of soda.

Barnyard manure increases the availability of native soil potash, as indicated by the work of Bartholomew (10), who suggests that the beneficial effect is due to the increased quantity of carbondioxide resulting from the breakdown of organic matter in manure. De Turk (26), however, did not find the potash in the native minerals rendered more available by the addition of manure or crop residues. He believes: "The so-called feeding power of the plant itself through the activities of the root system is an important factor in the utilization of relatively insoluble potassium."

Turning under cover crops or green manure crops renders available the usually insoluble potash minerals of the soil, according to the investigations of Hopkins and Aumer (41). Increase in the amount of organic matter in the soil increases the activity of soil microorganisms, which results in generation of more carbondioxide to dissolve the potash minerals. Also, as pointed out by Fraps (29), Prianischnikov (67), Headden (38), Ballentine (8), and others (24), the roots of plants are able to absorb a small percentage of the potash in the relatively insoluble mineral rocks (chemically "unavailable"). When the cover crops are turned 
under, this absorbed supply of potash is entirely available to the next crop. Cover crops also hold and prevent the leaching of soluble potash compounds when the main crop is not in the field.

Organic residues may also exist in the soil in a colloidal condition and may hold potash in a replaceable condition in the same manner as the mineral colloids.

Thus it is apparent that cover crops have a quadruple function in the liberation and conservation of potash.

Fertilizers that increase the acidity of the soil (such as sulfate of ammonia) also increase the amount of potash that is water soluble, and on the contrary, those that make the soil less acid decrease the water soluble potash (30). It should be remembered, however, that water solubility does not always mean increased absorption by the crop. Water soluble potash is easily leached as well as readily absorbed by the plant, and there are possibly some advantages in conserving it in a form that is water insoluble but at the same time available.

\section{LEACHING OF POTASH FROM THE SOIL}

The loss of potash from the soil by downward movement of water may vary widely. Differences in soil type, in crop removal, in rate of fertilization, and in amount of rainfall all combine to produce results from one set of conditions that are of doubtful application to any other.

Low rates of loss, such as 10 pounds to the acre annually, have been reported by Collison and Walker (20) for Florida conditions, Hendrick and Welch (39) for Scotland, Gerlach (34) for Germany, Crawley and Cody (21) for Porto Rico, and MacIntire, Shaw and Young (50) for Tennessee. Most of these studies were made on heavy types of soil, with somewhat higher outgo on sandier soils. However, Lyon and Bizzell (46), working with a silty clay loam in New York, found an average loss of 57 pounds per acre for all treatments and crop conditions, and on a silt loam the same authors (47) reported an annual loss of more than 100 pounds on fallow soil.

In contrast with earlier views, MacIntire and co-workers (50) have shown that the loss of potash may be materially decreased by the addition of liming materials, the amount of leaching being reduced as much as 21 per cent by high applications of burned lime materials. They have also shown (49) that by the application of lime materials the potash of a green manure may be fixed in the soil to the extent of one-half of the potash added.

In order to study the losses of plant food elements under conditions typical of the Connecticut Valley tobacco district, a series of lysimeter tanks was installed at Windsor in the spring of 1929. Two series of cylinders of 20 inch diameter were used, the first 
having 7 inches of soil (surface soil) and the second containing the normal surface soil placed over 12 inches of subsoil. The general plan of the installation is given by Morgan, Street and Jacobson (59) and need not be repeated in detail.

The series of shallow tanks, 34 in number, were filled with four different soil types on which tobacco is grown most extensively, as follows: Merrimac sand, a very light soil suitable only for shade tobacco production; Merrimac sandy loam, a typical light tobacco soil from the Station farm; Enfield very fine sandy loam, an upland soil of light texture but very retentive of water, on which type a considerable acreage of Broadleaf is grown; and Wethersfield loam, a reddish brown loam of rather high colloid content and typical of the heavier upland soils of glacial origin.

Fertilization of these soils varied only with respect to nitrogen source, the following carriers being used to supply the equivalent of 200 pounds of nitrogen per acre annually: Nitrate of soda, sulfate of ammonia, urea, and cottonseed meal. The potash, to the amount of 200 pounds per acre, was derived equally from sulfate and carbonate.

The 20-inch tanks were all filled with soil from one lot, the Merrimac sandy loam mentioned above, and the sources of nitrogen were: Nitrate of soda, nitrate of potash, nitrate of lime, sulfate of ammonia, ammophos "B", urea, calurea, cyanamid, cottonseed meal, castor pomace, linseed meal, fish, horn and hoof meal, dried blood, tankage, cow manure and no nitrogen. Potash fertilization was at the 200 pound rate, except that the nitrate of potash necessary to furnish the required amount of nitrogen also supplied 677 pounds of potash, and the castor pomace, through an error in analysis, supplied only 150 pounds in 1929.

The leachates were collected after each rain and composite samples analyzed at the end of each 6-month period. The potash removal from the surface soil tanks for the four 6-month periods from May 26, 1929, to May 25, 1931, is shown in Table 7.

Considering first the rate of loss as affected by soil type, it can be readily seen that the lighter soils permitted a greater outgo than the heavier types. In the summer of 1929, the rainfall was abnormally low, and the total amount of leaching, in terms of acre inches, was likewise low. The average loss of potash of the two lighter soils is almost exactly proportional to the loss of water, indicating a rather low base exchange capacity of the two soils. Between the Enfield and Wethersfield soils, however, no direct relation of water loss to loss of potash was found. The Enfield soil, while losing only two-thirds as much water as the Wethersfield, yet lost over three times as much potash, indicating the high absorptive power of the latter soil.

The losses during the following winter were higher than the summer losses on all soils except the coarse sand, the highest being 
found on the Enfield soil. This would indicate that this soil was able to hold the potash only temporarily. In fact the total loss for the year was very nearly the same for the first three soils, while

Table 7. The Leaching of Potash from the Surface Soll Lysimeter TANKS

\begin{tabular}{|c|c|c|c|c|c|c|c|}
\hline \multirow{3}{*}{$\begin{array}{l}\text { Soil and source } \\
\text { of nitrogen }\end{array}$} & \multicolumn{7}{|c|}{ Pounds potash per acre } \\
\hline & \multicolumn{2}{|c|}{ 1929-1930 } & \multirow{2}{*}{$\begin{array}{l}\text { Total } \\
\text { for } \\
\text { year }\end{array}$} & \multirow{2}{*}{\multicolumn{2}{|c|}{ 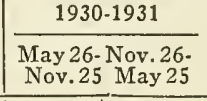 }} & \multirow{2}{*}{$\begin{array}{l}\text { Total } \\
\text { for } \\
\text { year }\end{array}$} & \multirow{2}{*}{$\begin{array}{l}\text { Total } \\
\text { for } 2 \\
\text { years }\end{array}$} \\
\hline & $\begin{array}{l}\text { May 26- } \\
\text { Nov. 25 }\end{array}$ & $\begin{array}{l}\text { Nov. 26- } \\
\text { May 25 }\end{array}$ & & & & & \\
\hline Merrimac coarse sand & & & & & & & \\
\hline Nitrate of soda & 28.617 & 21.771 & 50.388 & 38.271 & 24.376 & 62.647 & 113.035 \\
\hline Sulf. of ammonia & 31.326 & 31.441 & 62.767 & 41.586 & 31.768 & 73.353 & 136.130 \\
\hline Urea & 29.714 & 19.489 & 49.203 & 41.531 & 39.474 & 81.005 & 130.208 \\
\hline Cottonseed meal & 33.207 & 29.087 & 62.294 & 41.153 & 51.140 & 92.293 & 155.587 \\
\hline Average & 30.716 & 25.447 & 56.163 & 40.63 .5 & 36.689 & 77.324 & \\
\hline \multicolumn{8}{|l|}{ Merrimac sandy loam. } \\
\hline Nitrate of soda & 23.021 & 20.181 & 43.202 & 30.010 & 32.938 & 62.948 & 106.150 \\
\hline Sulf. of ammonia & 25.115 & 46.018 & 71.133 & 35.495 & 65.053 & 102.093 & 173.226 \\
\hline Urea & 24.098 & 37.046 & 61.144 & 30.739 & 44.559 & 75.294 & 136.438 \\
\hline Cottonseed meal & 26.588 & 37.045 & 63.633 & 32.829 & 65.979 & 98.808 & 162.441 \\
\hline No nitrogen & 24.952 & 34.631 & 59.583 & 30.054 & 46.458 & 76.512 & 136.095 \\
\hline Average & 24.755 & 34.984 & 59.739 & 31.825 & 50.997 & 82.822 & \\
\hline \multicolumn{8}{|l|}{$\begin{array}{l}\text { Enfield very fine } \\
\text { sandy loam }\end{array}$} \\
\hline Nitrate of soda & 15.712 & 35.906 & 51.617 & 26.242 & 42.650 & 68.892 & 120.509 \\
\hline Sulf. of ammonia & 13.756 & 50.651 & 64.407 & 23.711 & 111.404 & 134.115 & 198.522 \\
\hline Urea & 14.693 & 31.438 & 51.342 & 23.519 & 69.880 & 93.398 & 144.740 \\
\hline Cottonseed meal & 14.978 & 40.747 & 55.725 & 23.888 & 95.978 & 119.866 & 175.591 \\
\hline Average & 14.78 .5 & 39.685 & 54.470 & 24.340 & 79.978 & 104.318 & \\
\hline \multicolumn{8}{|l|}{ Wethersfield loam } \\
\hline Nitrate of soda & 5.821 & 6.178 & 11.999 & 10.103 & 13.291 & 23.393 & 35.392 \\
\hline Sulf. of ammonia & 5.298 & 8.023 & 13.321 & 22.843 & 42.162 & 65.004 & 78.325 \\
\hline Urea & 3.842 & 9.046 & 12.888 & 8.799 & 25.309 & 34.108 & 46.996 \\
\hline Cottonseed meal & 3.829 & 9.612 & 13.441 & 5.564 & 25.603 & 31.167 & 44.608 \\
\hline Average & 4.697 & 8.215 & 12.912 & 11.827 & 26.591 & 38.418 & \\
\hline
\end{tabular}

the soil of high colloid content (Wethersfield loam) had losses of only 25 per cent on the same basis. Similar observations might be made on the results for the second year, as the trend is the same in most particulars. The outstanding difference is the markedly higher loss on the Enfield soil during the winter period, 
which incidentally was featured by higher rainfall than any preceding period. Again the Wethersfield soil had a much lower annual loss.

The effect of the different nitrogeneous fertilizers on the outgo of potash is quite definite. Referring to the cumulative total for two years it can be seen that the use of nitrate of soda has resulted

Table 8. The Leaching of Potash from 20-Inch Lysineter Tanks

\begin{tabular}{|c|c|c|c|c|}
\hline \multirow[b]{2}{*}{ Source of nitrogen } & \multicolumn{4}{|c|}{ Pounds potash per acre } \\
\hline & $\begin{array}{l}19 \\
\text { May } 26- \\
\text { Nov. } 25 \\
\end{array}$ & $\begin{array}{l}930 \\
\text { Nov. } 26- \\
\text { May } 25\end{array}$ & $\begin{array}{c}\text { Total for } \\
\text { year }\end{array}$ & $1930-1931$ \\
\hline Nitrate of soda & 13.777 & 49.736 & 63.513 & 90.264 \\
\hline Nitrate of potash & 11.172 & 43.157 & 54.329 & 169.020 \\
\hline Nitrate of lime & 10.355 & 36.254 & 46.609 & 109.038 \\
\hline Sulfate of ammonia & 11.242 & 44.643 & 55.885 & 159.994 \\
\hline Ammophos "B" & 11.489 & 39.739 & 51.228 & 155.114 \\
\hline Urea & 13.693 & 39.066 & 52.759 & 104.331 \\
\hline Calurea & 11.824 & 44.242 & 56.066 & 96.888 \\
\hline Cyanamid & 12.513 & 44.928 & 57.441 & 113.739 \\
\hline Cottonseed meal & 13.939 & 37.303 & 51.242 & 122.411 \\
\hline Castor pomace & 14.497 & 48.581 & $63.078^{1}$ & 128.640 \\
\hline Linseed meal & 13.527 & 47.174 & 60.701 & 108.029 \\
\hline Dry ground fish & 12.281 & 38.855 & 51.136 & 131.824 \\
\hline Hoof and horn meal & 12.090 & 46.351 & 58.441 & 119.989 \\
\hline Dried blood & 13.314 & 42.857 & 56.171 & 122.589 \\
\hline Tankage & 11.196 & 38.900 & 50.096 & 123.993 \\
\hline Cow manure & 14.622 & 32.757 & 47.379 & 124.519 \\
\hline No nitrogen & 10.703 & 41.435 & 52.138 & 91.136 \\
\hline
\end{tabular}

in a lower loss than that caused by any other carrier, or on the Merrimac sandy loam, less than was found with no nitrogen. With this treatment, especially on light soils, practically all the nitrates in the soil go out as nitrate of soda, and the potash outgo is lowered accordingly. Sulfate of ammonia has very materially raised the leaching of potash, the increased outgo paralleling the increase in acidity of the soil. Urea and cottonseed meal are not widely different, although the latter material has caused greater losses in all soils except Wethersfield loam, where there is no real difference.

In the 20-inch tanks, all of which had soil as nearly identical as possible, the only difference in treatment being in the source of nitrogen, somewhat similar results to those on the shallow soil tanks were found. Table 8 gives the results for the first year by 6-month periods, and total for the second year.

\footnotetext{
${ }^{1}$ One hundred fifty pounds potash applied in 1929.
} 
No essential differences in potash outgo due to fertilizer treatment are to be noted for either the first or the second 6-month period. Nitrate of potash, furnishing 677 pounds potash per acre, produced no increase in the amount of potash in the leachate, while castor pomace, which supplied only 150 pounds, as compared with the standard amount of 200 pounds, had as high a loss as any treatment. The greater outgo during the winter as compared with the summer months of the first year, was in agreement with the losses that occurred in the shallow tanks, but more definitely emphasized. It agreed, moreover, with the water loss during the same periods, the winter leaching being two and a half times as large as the summer.

A rather higher level of potash leaching was found during the second lysimeter year, May 26, 1930, to May 25, 1931. This was correlated with higher rainfall, but differences due to the cumulative effect of the nitrogen fertilizers were also becoming more marked. The great excess of potash furnished by the annual addition of nitrate of potash was no longer so firmly held by the soil, and perhaps this treatment will continue to lose potash in increasing amounts. Sulfate of ammonia and ammophos "B" (which contains half its nitrogen as sulfate of ammonia) have begun to extend their acidifying effect to the subsoil, similar to their immediate effect in the surface soil, and the losses of potash are proportionately high. The repressive effect of nitrate of soda is also to be noted, the loss with this treatment being the lowest of all. Among the group of organic nitrogeneous fertilizers commonly used to supply the bulk of the nitrogen for the tobacco crop, no real differences are evident.

The results with the deep tanks, which show a higher average loss than the shallow tanks, would indicate that there is little if any retention of the potash brought by the soil solution into the subsoil, and that the solution becomes even more concentrated by passing through a greater depth of soil. Hence, these figures represent an actual loss of potash from the field.

In view of the large amount of potash removed by the tobacco crop itself, about 150 pounds to the acre for a good crop, the losses by leaching are of considerable aid in determining the quantity to apply. Crop responses (see p. 184 of this Bulletin) have shown that an annual application of about 200 pounds is necessary to produce tobacco year after year on the same field. A consideration of these data will show why this is sound.

On the three sandy soils, the average annual loss for all treatments in surface soil tanks was 72 pounds potash to the acre. Some potash is released from the native soil compounds, as shown previously in this Bulletin, and this quantity aids in maintaining the balance between input and outgo in the zone of greatest root activity. If it were not for this reserve, an outgo of 222 pounds 
could not be satisfied with an input of 200 pounds and the crop would suffer. It might be of interest to note that Morgan (57) found from 24,000 to 28,000 pounds of total potash in the surface 7 inches of tobacco soils in this state.

Although the losses of potash from the 20-inch tanks were higher than from the surface soils, a part of this loss was from a zone not as heavily drawn on by the tobacco root system. Nevertheless, it represents a loss from the total supply, and has considerable significance.

As compared with the annual loss, the outgo during the actual growing season of tobacco is not large. The average loss for the six months from May 26 to November 25 of each year was about 27 pounds, which was nearly half of that for the winter months, and for the period up to harvest of the tobacco, was perhaps 15 pounds per acre in the surface soil. This is a small quantity as compared with the nitrogen loss that might occur in the same period. Therefore, it is not likely that later side dressing with potash materials would be necessary or beneficial.

From the foregoing material, it would seem there would be no net accumulation of potash on cropped soils fertilized at the rate of 200 pounds per acre. In the case of the nitrate of potash deep soil tanks, a considerable fixation of potash must have occurred in the first year, but the losses in the second year would indicate that the soil does not have an unlimited capacity to store potash.

\section{POTASSIUM IN THE PLANT}

Absorbed through the roots in soluble mineral compounds, potassium is always present in considerable amounts in the transpiration stream of the plant. From this, it passes into the cells and infiltrates cell walls and all extra-cellular structures. McCallum (55) found it always absent from the nucleus, however. Concerning its distribution he states:

"Potassium occurs in both the cytoplasm and the extra-cellular structures. In the latter it is present as a product of impregnation and infiltration and as a consequence there are few structures that are free from it. In the inter-cellular material and in inert or dead matter it is usually very abundant.

"... The potassium in cytoplasm occurs in two conditions, that of physiological precipitation, and that of physiological or biochemical condensation.

"The precipitation is not a physical character but may perhaps be of the nature of fixation, in an inert form, of the potassium in passive colloidal material in the cytoplasm. This precipitation is 
the process apparently, by which living active cells dispose of the excess of potassium salts which may invade them in very great excess.

"In the condition of physiological or biochemical condensations, potassium salts in solution are concentrated in some particular part or parts of the cytoplasm and excluded from the remainder. This condition of condensation is a factor in the metabolic processes peculiar to cells.

"... That the salts can be in solution and at the same time confined strictly to parts of the cell is shown in Spirogyra in which the potassium is strictly localized in the immediate neighborhood of the chromatophor which is supposed to function in the synthesis of carbohydrates."

Although McCallum speaks of them as "precipitates" and "condensations," it should not be understood that the potassium compounds ever occur in an insoluble state. Kostytschew and Eliasberg (42) found all potash compounds in plants entirely soluble in cold water. From these facts it is evident that potassium is present only in an ionized condition, never in an undissociated combination with the protoplasm (as is the case with phosphorus and sulfur) or with other materials in the plant.

Fonder (28) found in alfalfa that "the potassium present in the green material of the alfalfa stems and leaves existed largely in solution in the plant sap, very little of it being held intimately in the woody tissue." Bartholomew and Jannsen (12) working with tomato plants state: "Practically all of the potassium may be removed from the plant through successive washings with water."

The solubility of the potash in cured tobacco leaves was determined by the following test: Samples (seconds) of tobacco from three plots of the 1928 crop were ground and then each divided into two portions. The first portion was analyzed for potash by the usual method of ashing and precipitating the potash as the chloro-platinate salt. The second portion was placed on filter paper in a large funnel and leached by running cold distilled water through it until the leachate came through clear. Then the amount of potash in the leachate and in the residue was determined and calculated to the basis of percentage of the original weight of leaf. The results presented in Table 9 show that all the potash compounds of the tobacco leaf are water soluble.

In view of this ready solubility of the potash compounds, is there a possibility of some of the potash being lost from the green leaves of the standing crop during long continued rains? The following test may partially answer this question. Entire green leaves were kept immersed (except for butts) in cold distilled water for 24 hours. Similar leaves from the same plants were analyzed and found to contain 5.272 per cent $\mathrm{K}_{2} \mathrm{O}$. After 24 hours the immersed leaves still contained 5.067 per cent $\mathrm{K}_{2} \mathrm{O}$ and the 
water .210 per cent $\mathrm{K}_{2} \mathrm{O}$ (all figures calculated to percentage of total dry weight of the leaves). In other words, about 4 per cent of the total potash in the leaves had been leached out by this treatment. Such treatment, however, is more severe than would occur during rains and it is not likely that even this much potash would be lost. It is not improbable that a certain small amount of potash is lost from living leaves during severe rains but the quantity is too small to cause serious concern.

Being so easily soluble in water, potassium is very mobile, that is, readily translocated from one part of the plant to another, wherever it is needed. Bartholomew and Jannsen (12) have

Table 9. Solubility of Potash Compounds in Cured Tobacco leaves

\begin{tabular}{l|c|c|c}
\hline & \multicolumn{3}{|c}{ Sample No. } \\
\hline \begin{tabular}{l|c|c} 
Percentage of potash in leaf, \\
determined after ashing
\end{tabular} & 5.77 & 4.47 & 5.48 \\
Potash found in leachate, on & & & 3 \\
$\quad$ basis of original weight & 5.73 & 4.45 & 5.46 \\
Potash found in leaf residue & 0.00 & 0.00 & 0.00 \\
\hline
\end{tabular}

shown that when the supply of potassium is too small for the needs of a growing plant, it is translocated from the older parts to the young growing organs and re-utilized. This may continue until the old leaves are almost entirely deprived and die for lack of potassium. That such a concentration of potash in the younger leaves does not occur in tobacco that has a sufficient potash supply, is indicated by numerous analyses of tobacco grown at the Windsor Station. These analyses show more potassium in the lower than in the upper leaves. That the reverse relation may exist where the potash supply is low is indicated by results of tests reported on page 183 of this Bulletin.

\section{Compounds of Potassium in the Plant}

Since extensive investigations have not been published, our knowledge of the compounds in which potassium occurs in tobacco plants is meager. There are present in the sap several other bases besides potassium. There is also a considerable list of acid ions. In what order and proportion are the bases combined with the acid radicals? The problem is rendered more complex by the ever changing composition of the sap during metabolism of the green plant. Besides the three dominant mineral bases, potassium, calcium and magnesium, there are much smaller quantities of sodium, iron, aluminum and manganese. Then there are organic bases (6) such as nicotine and ammonia. Besides the inorganic acid 
radicals, nitrate, chloride, sulfate, and phosphate, there are organic acids (77), malic, citric, and succinic, which Vickery and Pucher find to be in larger quantities than the mineral acids. Only exact and painstaking chemical determinations could prove what potassium compounds and their proportions exist in the plant, but certain combinations may be assumed on well-known chemical grounds.

Since potassium is the strongest base it would have the greatest affinity for acids. It would combine first with the nitrate and chloride which have the highest base avidity among the acids. According to various analyses which have been made on tobacco grown here $(4,6)$ there is about 1 per cent nitrate nitrogen (calculated as nitrate equal to about 4 per cent of the dry weight of the plant). The percentage, however, is extremely variable depending on fertilization and weather $(6: 245)$. It is thus safe to assume that a certain part of the potassium will be in the form of potassium nitrate. Behrens (13) found potassium nitrate concentrated particularly in the epidermis and in the colorless parenchyma of the ribs; hence the explosive sparkling combustion frequently observed in the ribs. In the elaboration of proteins, the nitrate is rapidly taken away and the potassium is left to combine with other acids, or with other nitrate ions. Our tobacco contains about .5 per cent of chlorine $(4: 44)$, which would also combine with the potassium. Since chlorine does not enter into synthesis of any of the plant substances, we may assume that there is always present in the sap a small amount of potassium chloride. The percentage of sulfate in our tobacco (aside from that organically combined) is about .3 per cent $(6: 212)$ and the percentage of total phosphate about 6 per cent. (Some part of it, however, is organically combined). In the presence of the high percentage of calcium (about 5 per cent) which forms highly insoluble salts with these anions, it is not to be anticipated that much of the potassium would be combined with the small amounts of sulfate and phosphate found. Therefore, if potassium sulfate and phosphate occur at all in the plant, they must be in very small quantities. After the cation requirements of the inorganic acids are all satisfied, there still remains a considerable proportion of the potassium which must be in combination with the organic acids. Vickery and Pucher (77: 191) found that 3.45 per cent of the dry weight of shade tobacco is organic acids, 85 per cent of which is malic, with much smaller quantities of citric, fumaric, succinic and oxalic acids. The oxalic acid is largely if not entirely combined with calcium. Malic and the other acids would be at least partly combined as potassium malate, citrate, and so forth. 
During the curing process, in which the sap is concentrated to about one twenty-sixth of its original volume (77), the greater part of the salts which have been in solution are crystallized out. The potash salts in cured tobacco must therefore be largely in crystalline form. The small amount of free water that still remains in cured tobacco must hold a saturated solution of potash salts.

\section{Role of Potash Salts in Absorption of Water by Cured Leaves}

After tobacco is cured in the shed, the leaves are so dry and brittle that they cannot be stripped from the stalks and put into bundles in fair weather without serious breakage. The grower must wait for a "damp," that is, a period of rain or foggy weather during which the leaves absorb enough moisture to make them soft and pliable. That such water absorptive capacity is largely dependent on the potash compounds in the leaf is indicated by the fact (discussed more fully in a later section of the Bulletin) that tobacco that had an insufficient supply of potash in the fertilizer does not readily come into "case," or become soft. This role of the potash compounds was demonstrated by the following experiment:

All the potash was leached from a lot of cured leaves by running water. Then, after drying, these leaves were saturated with 2 per cent solutions of several potash salts and again dried in an oven. After weighing, they were kept in a saturated atmosphere over night. The next day, they were weighed and found ta have absorbed the following percentages of moisture:

I.eaf treatment

Untreated

Phosphate, primary

Oxalate

Sulfate

Malate

Acetate

Hydrate
Percentage of water absorbed

12

31

55

62

85

126

190

It is quite possible that salts of other bases may play some part. but this experiment shows that the potash salts alone may account for all the absorption that is needed and in all probability are principally responsible for this property of cured tobacco. 


\section{RATE OF INTAKE BY THE PLANT}

As early as 1884, the French investigator Blot (16) reported the potash content of seedling tobacco plants and found that the whole plants of Connecticut tobacco contained 6.73 per cent potash, while the leaves of the same plants contained 8.06 per cent. Leaves of Sumatra tobacco at the same stage contained 10.54 per cent. Behrens (14) in 1892, reviewing the work of Blot (16) concludes that the percentage decreases as the plant grows in the field.

The work of Davidson (25) on White Burley, Medley Pryor, and Yellow Oronoko tobacco indicates that there is some decrease in percentage of potash with increasing maturity of the plants. His analyses of seedlings showed 8.22 per cent potash, but at the time of topping, the whole plants contained an average of 3.86 per cent, and, at harvest the content was 3.40 per cent.

The dimunition in percentage of potash with development of the plant has been demonstrated for a number of crops. Fonder(28) studied the potash content of alfalfa at various stages of growth, analyzing the leaves and stems separately. Table 10 , adapted from his work, shows the average of analyses of plants grown on seven types of soil.

Table 10. Percentage of Potash in Alfalfa at Different Stages of Growth. (Moisture Free Basis)

\begin{tabular}{l|c|c|c|c}
\hline \hline & \multicolumn{2}{|c}{ First growth } & \multicolumn{2}{c}{ Second growth } \\
\hline Stems & $\begin{array}{c}\text { May 8 } \\
\%\end{array}$ & $\begin{array}{c}\text { July 2 } \\
\%\end{array}$ & $\begin{array}{c}\text { July 24 } \\
\%\end{array}$ & $\begin{array}{c}\text { Full bloom } \\
\%\end{array}$ \\
\hline Leaves & 4.96 & 1.90 & 4.88 & 1.77 \\
\hline
\end{tabular}

Bartholomew and Jannsen (11) studied the potash content of various crops, with rates of fertilization ranging from no potash to 225 pounds in muriate of potash. One sample was taken in an early stage of growth, the second when the plant was in blossom. During that time, the average decreases for all rates of fertilization were as follows: Wheat, 2.36 per cent potash; cowpeas 0.32 per cent; soybeans 0.47 per cent.

In connection with a general project at this Station dealing with the rate of growth, samples of tobacco plants were taken at weekly intervals from a Havana Seed plot receiving standard fertilization (200 pounds potash to the acre) and cultural treatment. Plants as nearly representative as possible of the average growth at the time of sampling were taken in every case, the number of plants varying with the stage of growth. Table 11 shows the rate of intake in 1930. 
The figures showing pounds of potash taken up by an acre of tobacco should not be considered an absolute index of average intake under field conditions, because in later stages the number of plants taken for a sample was necessarily small, being reduced finally to a single plant. The general trend is shown more concretely by their inclusion, however.

Table 11. Intake of Potash by Tobacco Plants at Different Stages of Growth. (Moisture Free Basis)

\begin{tabular}{|c|c|c|c|c|c|c|c|c|}
\hline \multicolumn{4}{|c|}{ Stage of growth } & \multicolumn{2}{|c|}{$\begin{array}{l}\text { Part of plant } \\
\text { taken }\end{array}$} & $\begin{array}{c}\text { Percent } \\
\mathrm{K}_{2} \mathrm{O}\end{array}$ & $\begin{array}{c}\text { Grams } \mathrm{K}_{2} \mathrm{O} \\
\text { per plant }\end{array}$ & $\begin{array}{c}\text { Pounds } \mathrm{K}_{2} \mathrm{O} \\
\text { per acre }\end{array}$ \\
\hline & dling & & & Entire plas & & 8.00 & 0.0265 & 0.47 \\
\hline 9 & days & after & setting & Leaves an & talk & 5.93 & 0.0325 & 0.57 \\
\hline 17 & " & $"$ & " & " " & $"$ & 6.51 & 0.1102 & 1.94 \\
\hline 24 & " & " & " & " & " & 7.61 & 0.6453 & 11.35 \\
\hline 31 & “ & “ & " & $"$ & “ & 6.92 & 1.2315 & 21.67 \\
\hline 39 & “ & $"$ & “ & " & $"$ & 6.35 & 4.9912 & 107.82 \\
\hline $46^{1}$ & $"$ & $"$ & " & " & " & 5.77 & 6.4162 & 112.92 \\
\hline 54 & $"$ & " & $"$ & $"$ & " & 6.68 & 10.2538 & 180.42 \\
\hline 61 & “ & “ & " & " & “ & 5.99 & 10.7880 & 189.88 \\
\hline
\end{tabular}

Aside from the seedling stage, the percentage of potash of the plant does not show a regular decrease with increasing maturity of the plant, at least up to the time of harvesting of the field. Analyses of overripe tobacco show a sharp decline as the leaves begin to lose color, but this is a condition that would never exist under field technique. The most marked drop in potash percentage is from the seedling stage to the time of the first field sampling. During this time the plants suffer from transplanting, and make very little growth for as long as three weeks, although there is no absolute loss of potash. The two points at which the plants contained the highest percentage of potash correspond very well with the dates at which the plants showed the highest nitrogen percentage.

In terms of pounds per acre, the absorption of potash during the early growth in the field was a very small part of the total intake. The absorption at the end of three weeks was less than 6 per cent of the total for the season, and the intake at the end of four weeks, which represented half the growing period, was only 11 per cent of the total. The two weekly periods during which the total potash intake was the highest, from the 31st to the 39th day, and from the 46th to the 54th day, represent 45 and 35 per cent, respectively, of the total intake, and together they account for 80 per cent

1Plants budded 46th day, topped 50th day, and harvested 61st day. 
of the alssorption during the season. During the same weeks, 65 per cent of the total dry weight was added and 60 per cent of the total nitrogen was taken in by the plants. Thus it can be seen that the climatic conditions which favor the most rapid growth and nitrogen assinilation also largely determine the intake of potash. s.

\section{THE ROLE OF POTASH IN COMBUSTION OF THE CIGAR}

In the burning of a cigar, two distinct processes are readily seen, (1) the charring and (2) the ashing.

During the first, the charring process, the brown leaf is changed to black charcoal in a narrow region just ahead of the advancing red incandescent zone. This region appears outwardly as a narrow black band, frequently called the "coal band," and in different cigars may vary from one thirty-second to one-fourth of an inch in width. Generally speaking, the narrower the coal band, the better the burn is considered to be. It is a well founded belief of smokers that a broad coal band is associated with unpleasant taste and aroma. The charring process is the same as the dry distillation of wood or other vegetable material, practiced in the manufacture of charcoal. The transformation of the organic compounds, cellulose, protein, and the like, to carbon, is accompanied by the evolution as gas of combustible hydrocarbons, ammonia, nicotine, aldehydes, water vapor and a whole series of other volatile compounds. During the lighting of a cigar or a leaf with a match, the volatile hydrocarbons burn in the air with a flame and are consumed, but during the ordinary smoking of a cigar, they merely pass off in the smoke. The temperature during the charring process is about $600^{\circ}$ to $700^{\circ}$ C. according to Sligh and Kraybill (74) and is some $200^{\circ}$ lower than the temperature of the incandescent region. The black "char" which is left after completion of the first process consists of carbon and various mineral salts very finely and uniformly distributed within the carbon.

The second, or ashing process, is the same as the burning of charcoal (with which process most tobacco growers are familiar since they are accustomed to raising the temperature of the curing sheds by burning charcoal). At the higher temperature $\left(800^{\circ}\right.$ to $900^{\circ} \mathrm{C}$.) which prevails in the incandescent region, the carbon which results from the charring process is oxidized (burns) and passes off into the air as carbon dioxide. If this process of oxidation goes to completion, there will be left only the mineral salts (the most of which are pure white) and the ash will be white. If, however, the combustion is not complete, some of the black carbon will be left in the ash. The mixture of black carbon and white mineral salts gives a gray ash and the larger the quantity of unconsumed carbon, the more nearly black will be the ash. With incomplete combustion, the temperature is necessarily lower, which 
results in the evolution of volatile compounds which apparently differ either in composition or proportion from the volatile compounds produced during more complete combustion, and the resulting aroma is less pleasant. For the production of a pleasant aroma and taste it is important that the combustion should be as complete as possible. This is the scientific basis of the common opinion that a cigar with a white ash is better. The broader the coal band, the greater the proportion of leaf which is being distilled at a low temperature with disagreeable aroma; hence the advantage of a narrow coal band.

Another important essential of a good cigar is that it shall continue to burn (glow, or hold its fire), for a long time after the air is drawn through by the smoker. A good cigar should continue to burn for at least five minutes after puffing ceases and we have found many that will attain ten minutes. Almost any cigar may be made to burn by continuous puffing, but smoking in this way is unpleasant. The average smoker prefers to draw intermittently with fairly long resting periods between puffs. If, during this rest period, the combustion is dying out, the temperature is again lowered with the volatilization of unpleasant odors as mentioned above, hence the advantage of a long fire-holding capacity.

Both the completeness of combustion (measured by ash color) and the length of the burn (fire-holding capacity) are governed largely by the character, quantity and proportion of the mineral salts which the tobacco contains. The most important of these are the compounds of potash. As far as fire-holding capacity is concerned, this may be easily demonstrated. If a leaf of cured tobacco with good fire-holding capacity is leached for 24 hours with water and then tested, it will be found to contain no potash, as we have previously explained on page 158. When it is dried and ignited it will still have no fire-holding capacity, but will burn only with a flame, like paper. If potash is again introduced by soaking with a 1 per cent solution of potassium carbonate, citrate, or other potash salt, it will be found that the fire-holding capacity has been restored, which shows that potash is the only element needed to impart fireholding capacity.

This influence of potash salts has been confirmed by the investigations of numerous scientists $(4,5,6,7,9,15,32,36,43,54,62$, $64,66,68,71,76)$ and, in a general way, it was found that those tobaccos with the largest content of potash have the longest fireholding capacity. Yet it was long ago found that all compounds of potassium do not have the same capacity for promoting burn. Certain of the acid radicals have the property of neutralizing the good effect of potassium.

A number of investigators have tested the effect of each of the common salts of potash on fire-holding capacity by impregnating tobacco leaves or pieces of filter paper with solutions of the dif- 
ferent salts and then, after the latter had dried, determining the length of time each would continue to burn (glow) after ignition. The results reported by different writers have not been altogether consistent. The differences are probably due mostly to the use of different methods, different concentrations or salts and possibly different types of tobacco and standards of judgment. In order to compare the effects of these same salts on our types of tobacco the tests were repeated by the writers according to the following method:

Cured leaves from the low potash plots were thoroughly leached by running water over them for 18 hours. They were found to be free of potash, were thoroughly dried, and then immersed in .5, $1,2,4$, and 8 per cent solutions of each of 11 potash salts. After thorough saturation, the leaves were completely dried again and then the fire-holding capacity was determined by ignition with an electric filament. Since it was found that the dried leaf will absorb a solution to the extent of three and one-half to four times its weight, it is apparent that when dried after impregnation, the actual percentage of the salt that the dry leaf contained was about three and one-half to four times that of the solution. Therefore the leaves treated with the 4 and 8 per cent solutions contained a concentration of potash higher than would ever occur naturally in the leaf.

The untreated check leaves (leached but not impregnated with a potash salt) burned like paper with a flame, but had no capacity for carrying or spreading the incandescent combustion. When they were heated at a high temperature and the carbon oxidized they gave a flaky white ash, obviously due to the high percentage of calcium and magnesium salts in the tobacco from these plots. Observations on duration and spread of the combustion circle, and the color and consistency of the ash are recorded in Table 12.

From this series of tests we may draw certain conclusions:

All of these salts of potassium have the property of imparting fire-holding capacity to a leaf unburnable without them, at least at certain concentrations.

The degree of fire-holding capacity imparted differs greatly, with the salt used and with the concentration of any one salt.

The lightest colored ash invariably coincides with the lowest concentration of the potash salt. With each increase in concentration of potassium, the ash becomes progressively darker until it is coal black. This is in agreement with our previously published finding ( $7: 391)$ that the ash color depends primarily on the ratio of magnesium to the potassium.

Salts or concentrations which cause fusion invariably give black ash and poor fire-holding capacity. 


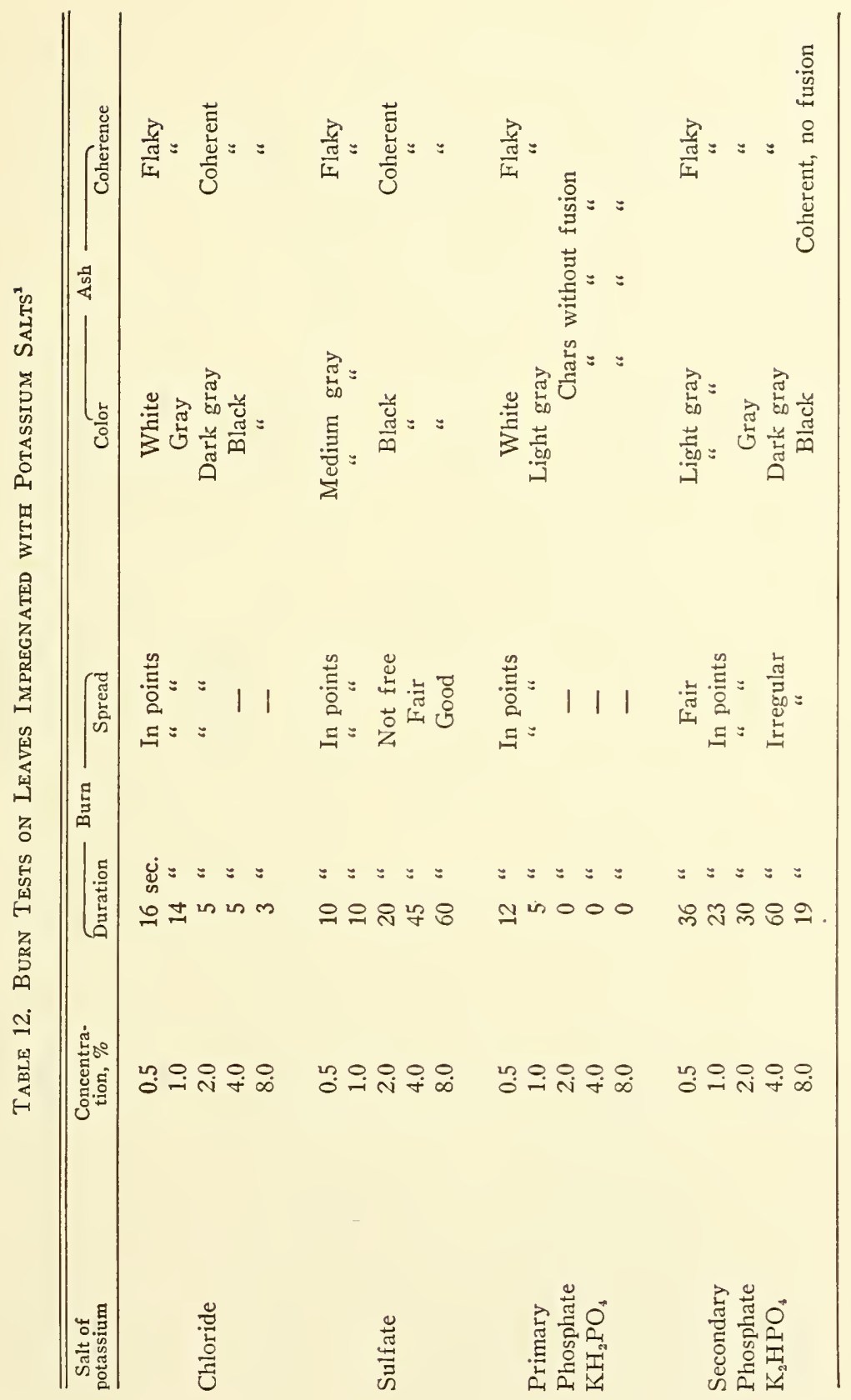




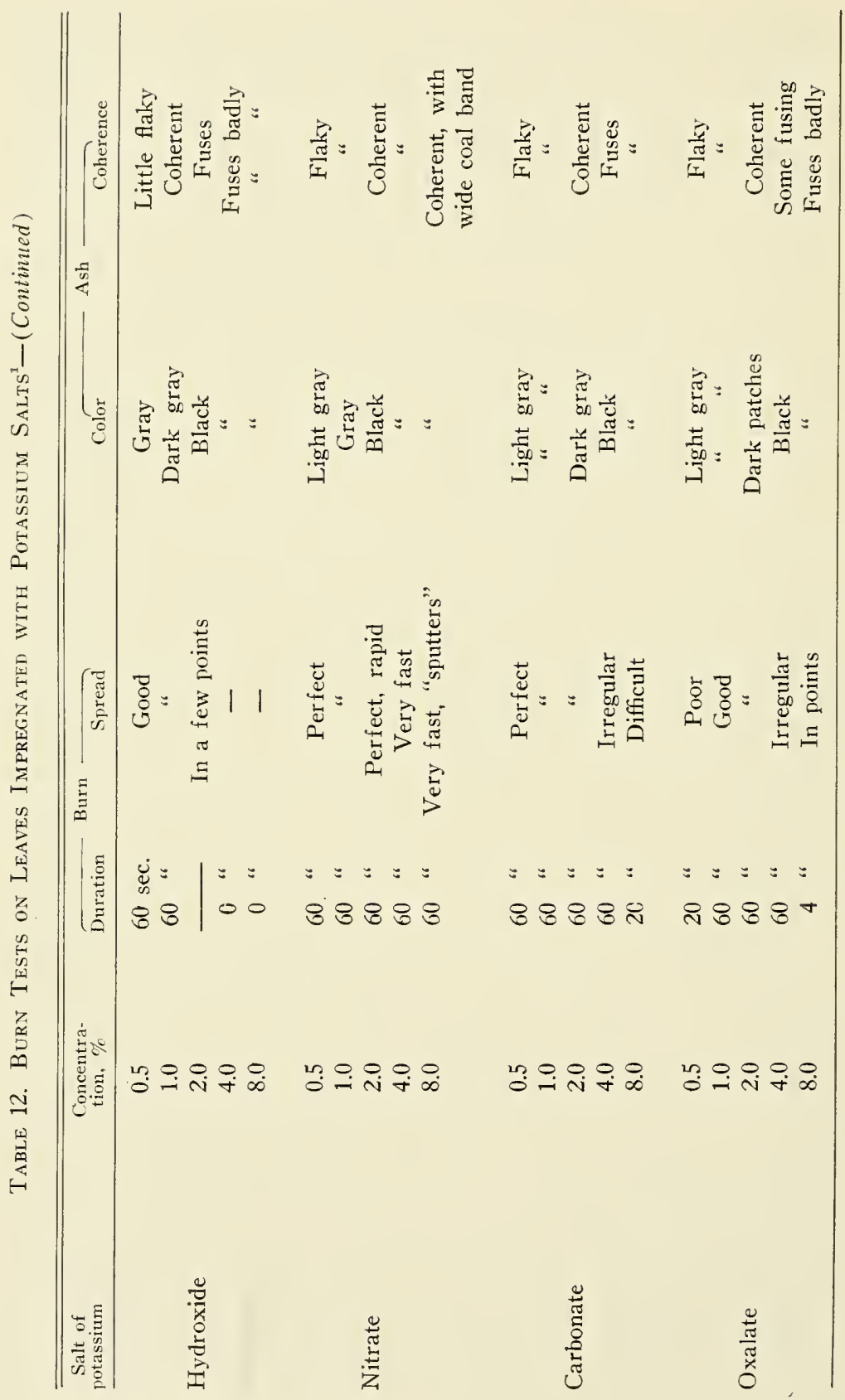




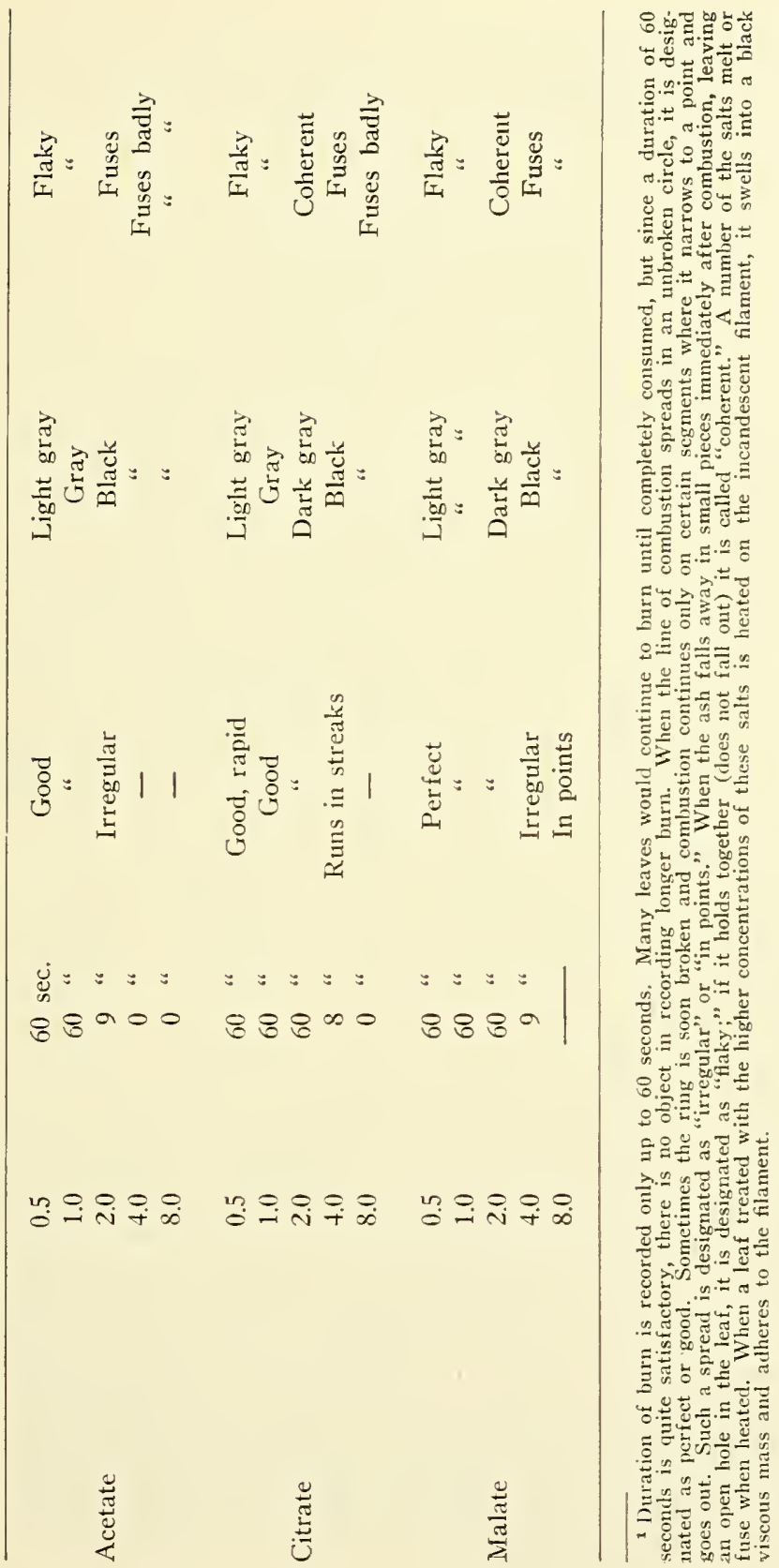


Potassium is absolutely essential to fire-holding capacity of tobacco and up to a certain point, each increase in potassium will increase the fire-holding capacity (see Figure 18). This point differs with different salts. Increases beyond this point will injure rather than improve the burn.

Chloride. This material has usually been considered the most injurious to burn of all the acid radicals and has been investigated more than any other. It deserves this rank, not because its effect is more deleterious than some others at the same concentration but because of the greater avidity with which the plant absorbs it if there is a supply in the soil, that is, injurious concentrations in the leaf are more likely to occur. Our tests indicate that at the lower concentrations it is one of the less efficient salts in promoting burn but at higher concentrations it completely ruins the burn.

Tobacco with a high percentage of chlorine is almost unburnable but the ill effect of a small amount of chlorine may be overcome if the percentage of potash is raised. After years of experiment, Nessler (63) formulated the rule that no tobacco would have a good burn which had less than 2.5 per cent of potash or more than .4 per cent chlorine, or, in other words, the potash content must be five or six times as large as the chlorine content. Thus he analyzed 47 samples of tobacco grown in southern Germany in 1888 which showed the following percentages of potash and chlorine and relative burn:

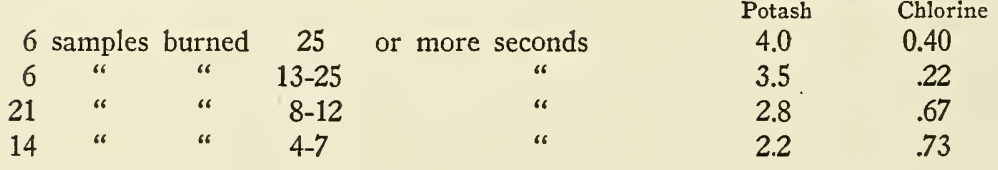

Sulfate. With respect to sulfate, there is some difference of opinion. Nessler (62) and Mayer (54) considered it beneficial, but their conclusions were based on tests with impregnated filter papers. Kraybill (43) found sulfate of potash favorable to burn. Schloesing (71) considered it harmful like chlorine. Van Bemmelen (15) and Fesca and Imai (27) agreed with Schloesing. Garner's (32) results were quite the opposite from Nessler's. He says: "The sulfate when added in any considerable quantity invariably injurcd the burning qualities very markedly, acting in this respect very much like the chloride but to a lesser degree." Tests conducted by the writers in 1930 with leaves impregnated with .5 and 1 per cent solutions of potassium sulfate gave results fully in agreement with those of Garner. 
In the experiments recorded in Table 12, the lower concentrations of sulfate of potash showed a weak ability to promote fireholding capacity, but with increasing concentration the fire-holding capacity was improved until it was almost perfect at the highest concentration. This condition appears to be peculiar to the sulfate, and is possibly due to a limited capacity of this salt to supply oxygen. Sulfate would never occur naturally in the leaves in such concentrations as those which show the beneficial effect in this table. At the low concentration in which sulfate occurs in our tobacco, its injurious effect can consist only in its displacement of other acid radicals which would be more beneficial to burn.

Phosphates. Barth (9) and Mayer (54) found phosphates to be extremely injurious to burn. Kraybill (43) on the other hand found that di-potassium phosphate and tri-potassium phosphate improved the burn. Garner (32) found that the di-potassium phosphate was without any effect either way. Our own tests indicate that mono-potassium phosphate in weak concentrations is the least beneficial of all the salts in promoting fire-holding capacity, while with stronger concentrations the leaf has no fire-holding capacity at all. The di-potassium salt, however, has considerable ability to promote the burn, but not to the same extent as the organic salts.

From the review it is apparent that these inorganic salts of potash are either harmful or have no decided favorable influence in promoting the fire-holding capacity.

Nitrate of potash. This material promotes fire-holding capacity, but if present in any considerable quantity, causes minute audible explosions or sparkling. Nessler (62) found that it produced a black ash and also a broader coal band than the other potash salts. Mayer (54), too, found that nitrate promoted burn. Garner (32) says: "Potassium nitrate in large quantities causes tobacco to burn explosively and the combustion is incomplete; in smaller quantities it exerts a distinctively beneficial action, but not more so than other potash salts. The quantity of potash combined with nitric acid in tobacco is generally comparatively small, and other forms of potash are more important in promoting fire-holding capacity." Our results agree with those of the above investigators in showing that the nitrate gives perfect fire-holding capacity, but, except in the lowest concentration, it results in a very black ash and a wide coal band, both of which are undesirable features. The line of combustion spreads very rapidly with audible sputtering and sparkling.

Organic salts. Investigators almost perfectly agree that the organic salts of potash (citrate, malate, acetate, and so forth), greatly improve the fire-holding capacity. Our own results with the organic salts, and the carbonate, fully accord with those of 
previous investigators and indicate that these materials have the most beneficial influence on burn. As far as potash alone has an influence on this property it may be stated that the length of fireholding capacity is proportional directly to the amount of potash which is free to combine with the organic acids. In the ashing of tobacco, the organic acids are changed to carbonates (not true of chloride, phosphate and sulfate), and since these alkaline substances are water soluble it has been found that the fire-holding capacity is proportional to the alkalinity of the water soluble portion of the ash. The fire-holding capacity is, however, influenced to some extent by other factors, such as structure of leaf, amount of gum, protein, fats, and so forth, but when these variations are discounted, the best chemical measure of burnability of any lot of tobacco seems to be the alkalinity of the water soluble ash. This principle was first set forth by Schloesing in 1860 and has been confirmed by the researches of a large number of investigators since he first published his results $(6,9,15,36,54,62,64,66,68)$.

The most plausible explanation yet advanced for the favorable influence exerted by most potassium salts in promoting fire-holding capacity is the one advanced by Nessler and Mayer, which is that it is due to their easy reduceability. At the temperature of a burning cigar, they give up their oxygen to oxidize the carbon at the instant when it is most favorable. Such oxygen is ideally distributed within the burning carbon and is therefore more effective than oxygen from the outside. The potassium that has thus been reduced to a metallic state is burned to oxide as soon as it leaves the sphere of reduction. In other words, potassium acts as a catalizer. This theory also explains why phosphate and other salts which can not be reduced easily do not have a very favorable influence on the burn. The chloride naturally has no oxygen to give off and hence its inability to aid combustion.

The injurious influence of many salts in giving a black ash is due to the fact that they fuse (or melt) at a low temperature and enclose or encase the finely divided carbon particles so that the air has no access to them and they cannot be burned. This influence was most evident in the case of the hydroxide.

In comparison with other bases, the potash compounds as a whole do not produce a white ash. In a previous article $(7: 391)$ the writers have shown that it is necessary to have a certain proportion of magnesium to potassium if a white ash is desired. These magnesium salts do not fuse, but on burning they produce a loose porous ash permitting perfect access of air to the finely divided carbon, which results in complete combustion.

Reasoning from the fully demonstrated function of potash in promoting fire-holding capacity, one might conclude that in practice, every effort should be made to raise the percentage in the leaf to the highest possible point. This is true, however, only to a certain 
limit. Not only will the law of diminishing returns operate to make such a practice extravagant, if carried to its limit, but also, too great a proportion of potash may, by its antagonistic effect, reduce the percentage of magnesium and thus tend to give a darker ash.

\section{HOW MUCH POTASH SHOULD BE USED ANNUALLY IN THE FERTILIZER}

We have previously indicated that a good tobacco crop removes from an acre of soil about 155 pounds of potash. Moreover, we have shown that 40 to 130 pounds of potash leach out of the soil during the year. Accepting, however, Hopkin's estimate (40) that about one-quarter of 1 per cent of the native mineral potasin comes into an available condition annually and knowing that there are some 25,000 pounds of native potash in our soils, it may be assumed that the leaching about offsets the amount becoming available each year. The fallacy of judging fertilizer requirements by crop analyses has long been known but it is reasonable to assume that no less amount of potash should be applied in the fertilizer annually than the 155 pounds which the crop removes. This figure might be reduced by the 47 pounds of potash in the stalks if they are returned to the field after stripping. It may also be argued that a considerable part of the 108 pounds of potash (which is an average amount removed in the leaves of our crops on the Station farm) is not necessary, but may be ascribed to luxury consumption even beyond the combustion requirement.

The best quantity to apply is obriously the amount that will satisfy both the physiological needs and the requirements for fire-holding capacity, without a wasteful excess, which may even be harmful. This requirement may differ somewhat from year to year and also with the type of soil. To this problem, which varies with so many unknown or only estimated factors, it is obvious that an answer cannot be given until actual field tests, replicated and continued through a series of years on several types of soil, are carefully conducted.

Such field experiments conducted in other sections of this country or other countries may be helpful, but are of only minor value to us because of differences in soil, climate and desired qualities of tobacco raised in a given section. In the Connecticut Valley, quantitative experiments were not recorded before the establishment of the Windsor Tobacco Station, except for one plot in the Poquonock experiment conducted by Dr. Jenkins in 1892-96 (summary in Conn. Agr. Expt. Sta. Rpt. for 1896, p. 319). In this experiment, the standard application of potash was 340 pounds per acre. On plot $\mathrm{F}$ this was reduced to 150 pounds for four years and compared with plot B, treated with 340 pounds. Cotton- 
hull ashes were used in both cases. It was found that the average yield was larger on the $F$ plot (150 pounds potash) by nearly 100 pounds and that the quality was just as good as where the larger quantity of potash was applied. From this experiment, Dr. Jenkins concluded that 150 pounds of potash was sufficient. Two conditions of this experiment, however, make the value of conclusions drawn from it questionable. (1) The plots were not replicated and (2) the difference of 900 pounds in the annual application of cottonhull ashes between the two plots might be expected to produce other soil variations on account of the large quantities of lime and other compounds which this material contains.

Two series of field tests have been conducted at the Windsor Substation to determine the best quantity of potash to apply. Since these were on different fields, each of which had a different soil and also since they were started in different years, each will be discussed separately. For a more detailed progressive discussion of these experiments the reader is referred to the annual reports of the Tobacco Substation (5: 147-154, 6: 207-210, $7: 368-373$ ). It will be sufficient here to present merely summary tables and our conclusions from the experiments as a whole.

\section{Quantitative Series of 1926}

This is the series designated in our reports as the "old quantitative series." It was begun in 1926 on Field V of the Experiment Station farm, with six one-fortieth acre plots. The soil in this part of the field is quite uniform and is a coarse sandy loam or loamy sand with coarse sandy subsoil, subject to rapid leaching. This soil is of the Merrimac series, typical of the soils on which much of our shade tobacco and some of the out-door types are grown. The tobacco here usually suffers from leaching of the fertilizer during wet years and lack of moisture during dry years. It never produces a heavy crop, but the tobacco is usually of good quality and color if the season is not extreme. During the dry seasons of 1930 and 1931 the plots were irrigated by running water between the rows. Havana seed type of tobacco was used in this, as in all the experiments recorded in this Bulletin. The land had been uniformly fertilized and grown to tobacco for many years before this experiment was started.

The fertilizer used was our standard mixture modified to contain different quantities of potash on the different plots. On two plots, the standard application of 200 pounds potash $\left(\mathrm{K}_{2} \mathrm{O}\right)$ per acre was used. On two more, the quantity was reduced to 100 pounds potash. On the other two, all special carriers of potash were omitted. These last two plots, however, really received about 40 pounds of potash in the cottonseed meal and castor pomace. All potash could have been excluded from the fertilizer by the 
use of a mixture of pure chemicals, but since a purely chemical mixture without organic materials is never used by growers on Connecticut tobacco fields, and results obtained through the use of such a formula would have no direct application to practical conditions, it was thought best to use the organic materials even though by so doing we could not have a formula entirely devoid of potash. The potash (except for that in the organic materials) was derived in equal amounts from nitrate, sulfate and carbonate of potash. This distribution of the potash was chosen because (1) previous tests had shown this to be a satisfactory formula and (2) by this division, the supplementary effect of a large amount of any one of the acid radicals would be minimized. Each formula contained 160 pounds of nitrogen in the organic materials and 40 pounds of nitrogen in the nitrate form. Each also contained 160 pounds per acre of phosphoric acid. The composition of three formulas is given in Table 13. The fertilizer was applied and harrowed in about 10 days before the plants were set.

Table 13. Composition of the Three Fertilizer Mratures Used in the Quantitative Series

\begin{tabular}{l|c|c|c}
\hline \hline \multicolumn{1}{c|}{ Name of material } & $\begin{array}{c}40 \mathrm{lbs} . \mathrm{K}_{2} \mathrm{O} \\
\text { Formula K11 }\end{array}$ & $\begin{array}{c}100 \mathrm{lbs} \mathrm{K}_{2} \mathrm{O} \\
\text { Formula K12 }\end{array}$ & $\begin{array}{c}200 \mathrm{lbs} . \mathrm{K}_{2} \mathrm{O} \\
\text { Formula K9 }\end{array}$ \\
\hline Cottonseed meal & 1765 & 1765 & 1765 \\
Castor pomace & 741 & 741 & 741 \\
Nitrate of soda & 260 & 225 & 165 \\
Precipitated bone & 278 & 278 & 278 \\
Sulfate of potash & 0 & 40 & 109 \\
Carbonate of potash & 0 & 30 & 82 \\
Nitrate of potash & 0 & 43 & 119 \\
\hline
\end{tabular}

Field observations. During the first year of this experiment (1926) no differences in growth or appearance of crop in the field were observed. The growth on all these plots, however, during that year was unsatisfactory because of the very dry weather and no conclusions were drawn, either from the field observations or from the sorting records.

During the second year, the growth on the 40-pounds-potash plots appeared smaller, but there were no differences observable between the 100-pound and 200-pound plots. During the following years, this difference in luxuriance of growth was more pronounced, so that the 40 -pounds-potash plots could be distinguished easily from the others by the stunted growth and shorter leaves. The crop of 1929 , when about ready for harvesting, was ruined by hail and immediately turned into the soil and a cover crop of oats sowed. During the following year (1930) the differences 
were less marked, probably because of the accumulation of potash taken up and returned to the soil by both the crop of tobacco and the cover crop.

Throughout the experiment, the 40-pounds-potash plots could also be distinguished on hot days by the fact that the leaves wilted and flagged before any others. Yet these plants never showed the acute symptoms of potash hunger described on page 140 of this Bulletin except that when they were full grown some of the upper leaves showed the recurved yellow-mottled tips (as illustrated on the leaves shown in Figure 16). In 1931, however, in an experiment to determine the effect of lime on potash depression, one of the 40-pounds-potash plots and one of the 100-pounds-potash plots were treated with hydrated lime at the rate of 1000 pounds per acre at the time of spreading the fertilizer. This apparently had the effect of reducing the potash to a point below the physiological requirements of the plant, because then the symptoms characteristic of acute potash starvation, hobbly surface and recurved margins, could be observed, particularly on the lower leaves of the plants on the 40-pounds-potash plot. These symptoms, however, seemed to come and go throughout the season and when the crop was harvested they were not so noticeable as during the earlier part of the season. Such symptoms were not seen on the 100pounds-potash plots even when limed.

Observations on the cured tobacco. Each year at the time of taking down the cured tobacco from the shed and stripping, it was found that tobacco from the 40-pounds-potash plots did not come "into case," or, become soft and pliable through absorption of moisture from the air during "damps." Adjacent plots in the shed were in excellent condition for handling while this tobacco was hard and dry and never became really ready to take down. The same was true, but to a smaller degree, of tobacco from the plots where only 100 pounds of potash had been applied. From these observations it is apparent that the potash salts by their high degree of hygroscopicity are at least largely responsible for the capacity of good tobacco to absorb moisture from the air and thus cone into suitable condition for handling during damp weather.

On the sorting bench, each year the tobacco from the 40-poundspotash plots was found to be short, thick, "boardy," dry, yellow, non-elastic and of such inferior quality generally that commercially it would not pay to sort.

Yield of leaf. Total yield of leaf for the six plots for the years 1927-1931, calculated to an acre basis, is presented in Table 14. The low yields for 1927 and 1928 were due to the extremely rainy season and are in line with all other yields for those years, especially on this type of soil. 
The results show that there has been only a small reduction in yield produced by reduction of quantity of potash applied. Otryganjew (65), working with tobacco grown in Russia, and Cserhati in Hungary (22) also found that the quantity of potash applied in the fertilizer had little effect on the weight of the crop produced. Bartholomew and Jannsen (11 and 12), working with crops other than tobacco, also found that increase in potash content did not increase yields.

These results, however, should not be interpreted to mean that the weight of the crop will be the same regardless of the extent to which potash is reduced in the soil. There is obviously a wide range through which this is true but a point may finally be reached where reduction in yield will begin. Apparently Moss and associates (60)

Table 14. Yield of Cured Leaf on the Quantitative Series of 1926

\begin{tabular}{|c|c|c|c|c|c|c|}
\hline \multirow{2}{*}{$\begin{array}{l}\text { Lbs. potash } \\
\text { per acre }\end{array}$} & \multirow[b]{2}{*}{ Plot No. } & \multicolumn{4}{|c|}{ Acre yield by years } & \multirow{2}{*}{$\begin{array}{c}\text { Average } 4 \\
\text { years }\end{array}$} \\
\hline & & 1927 & 1928 & 1930 & 1931 & \\
\hline & K11 & 1150 & 1107 & 1430 & 1478 & \\
\hline 40 & K11-1 & 1137 & 1163 & 1306 & 1323 & 1262 \\
\hline & $\mathrm{K} 12$ & 1147 & 1107 & 1541 & 1652 & \\
\hline 100 & K12-1 & 1141 & 1076 & 1304 & 1396 & 1295 \\
\hline & K9 & 1152 & 1178 & 1470 & $1529 *$ & \\
\hline 200 & K9-1 & $(1152)$ & 1221 & 1422 & $1532 *$ & 1332 \\
\hline
\end{tabular}

in North Carolina and Garner and Brown (33) in Maryland were working with soils that had reached this point of deficiency, and applications of potash up to a certain point gave corresponding increases in yield. In Maryland, it was found that new or rested lands did not show this need, but with continuous cropping, it was necessary to apply potash at least to the extent of 15 to 30 pounds per acre to keep up the yield. Likewise Mathewson (53) was able to increase the yield of flue cured tobacco in North Carolina by as much as 200 pounds in some experiments by addition of potash to the fertilizer.

Apparently our lowest application ( 40 pounds) is close to or just below the minimum that will keep up the yield on this soil, that is, it will just about meet the physiological needs of the crop.

Effect on the grading. The effect of a low supply of potash on the quality or grading of the tobacco is much more serious than

*N11 and N11-1 substituted in 1931. The K9 and K9-1 plots were not planted that year. 
the effect on the weight as may be seen from Table 15, which gives the grade indexes ${ }^{1}$ of the same crops.

The undesirable characters of this tobacco were most pronounced on the 40-pounds-potash plots (K11 and K11-1), but on the 100pound plots these characters were present to a lower degree. Tobacco from the 200-pounds-potash plots was rated as of good quality. It exhibited none of the dry, thick, non-elastic, yellow characteristics of the other plots.

Table 15. Grade Index of Tobacco from Quantitative Series of 1926

\begin{tabular}{|c|c|c|c|c|c|c|}
\hline \multirow{2}{*}{$\begin{array}{l}\text { Lbs. potash } \\
\text { per acre }\end{array}$} & \multirow{2}{*}{ Plot No. } & \multicolumn{4}{|c|}{ Index by years } & \multirow{2}{*}{ Average } \\
\hline & & 1927 & 1928 & 1930 & 1931 & \\
\hline 40 & $\begin{array}{l}\text { K11 } \\
\text { K11-1 }\end{array}$ & $\begin{array}{l}.281 \\
.298\end{array}$ & $\begin{array}{l}.194 \\
.233\end{array}$ & $\begin{array}{l}.349 \\
.284\end{array}$ & $\begin{array}{l}.260 \\
.229\end{array}$ & .266 \\
\hline 100 & $\begin{array}{l}\text { K12 } \\
\text { K12-1 }\end{array}$ & $\begin{array}{l}.368 \\
.364\end{array}$ & $\begin{array}{l}.321 \\
.324\end{array}$ & $\begin{array}{l}.367 \\
.338\end{array}$ & $\begin{array}{l}.385 \\
.252\end{array}$ & .340 \\
\hline 200 & $\begin{array}{l}\text { K9 } \\
\text { K9-1 }\end{array}$ & $\begin{array}{c}.411 \\
(.411)\end{array}$ & $\begin{array}{l}.428 \\
.498\end{array}$ & $\begin{array}{l}.419 \\
.434\end{array}$ & $\begin{array}{l}.334 * \\
.324 *\end{array}$ & .407 \\
\hline
\end{tabular}

\section{Quantitative Series of 1927}

This series, begun in 1927 and designated as "the new potash series" in our reports, was on Field I at the Experiment Station, a field that has a soil more favorable to the growing of Havana Seed tobacco. It is a fine sandy Merrimac loam not subject to serious leaching. This is the type of soil on which a considerable part of the Havana Seed and Broadleaf tobacco on both sides of the Connecticut River is grown. This series consisted of 16 onefortieth acre plots. The fertilizer formulas were just the same as those used in the preceding series, except that on five of the plots (K13) the quantity of potash was raised to 300 pounds per acre. Since the soil on this field was considered too acid for best results it was limed at the rate of 400 pounds of ground limestone per

\footnotetext{
${ }^{1}$ In comparing the quality of tobacco grown on different plots it is very difficult to keep in mind the percentage of eight commercial grades of tohacco from one plot and compare it with a like number from another. To simplify this comparison a grade index is used. The grade index is a single number expressing the grading of all the tobacco grown on a particular plot. It is based on the percentage of carefully assorted commercial grades and the relative value of the different grades. Although market prices vary from year to year, the ratios of prices between the different grades are fairly constant. The comparative values for the different grades are as follows:

$\begin{array}{lllll}\text { (L) Light wrappers } & 1.00 & \text { (LD) Long darks (19 in. up) } & .30 \\ \text { (M) Medium wrappers } & .60 & \text { (DS) Dark stemming (17 in.) } & .20 \\ \text { (LS) Long sec. (19 in. up) } & .60 & \text { (F) Fillers } & .10 \\ \text { (SS) Short seconds (15 in. and } & & \text { (Br) Brokes } & .10 \\ & 17 \text { in.) } & .30 & & \end{array}$

The grade index of any plot is obtained by multiplying the percentage of each grade by the comparative value in the above schedule, adding the products and dividing by 100. The grade index is a relative figure and is not intended to represent market price at any time.
}

*N11 and N11-1 substituted in 1931. 
acre in 1928 and again in 1929, and with 400 pounds hydrated magnesian lime (29 per cent $\mathrm{MgO}$ ) in 1930. The precipitated bone was omitted from the formulas in 1927, 1930, and 1931 because previous experiments on this field showed that the tobacco did not respond to phosphoric acid.

Field observations. No differences in growth as between the different treatments were observed during the first year but during subsequent years, the rows on the 40-pounds-potash plots (K11) appeared less luxuriant and "leafy" than those on the other plots. No acute symptoms of potash starvation were observed except for a few recurved yellow tips on the 40 -pounds-potash plots. Wilting during dry hot weather occurred first on the 40-pounds-potash plots just as in the preceding series.

Table 16. Yieli of Cured Leaf in Quantitative Potash Series of 1927

\begin{tabular}{|c|c|c|c|c|c|c|}
\hline \multirow{2}{*}{$\begin{array}{l}\text { Potash, } \\
\text { 1bs. per acre }\end{array}$} & \multirow{2}{*}{ Plot No. } & \multicolumn{4}{|c|}{ Pounds of cured leaf } & \multirow{2}{*}{ Average } \\
\hline & & 1927 & 1928 & 1930 & 1931 & \\
\hline \multirow{5}{*}{40} & K11-2 & 1230 & 1259 & 1828 & 1792 & \multirow{5}{*}{1478} \\
\hline & $\mathrm{K} 11-3$ & 1213 & 1114 & 1813 & 1711 & \\
\hline & $\mathrm{K} 11-4$ & 1160 & 1152 & 1782 & 1666 & \\
\hline & $\mathrm{K} 11-5$ & 1152 & 1185 & 1884 & 1644 & \\
\hline & $\mathrm{K} 11-6$ & 1163 & 1312 & 1758 & 1743 & \\
\hline \multirow{3}{*}{100} & $\mathrm{~K} 12-2$ & 1287 & 1202 & 1864 & 1869 & \multirow{3}{*}{1594} \\
\hline & $\mathrm{K} 12-3$ & 1384 & 1306 & 2080 & 1800 & \\
\hline & $\mathrm{K} 12-4$ & 1152 & 1083 & 1890 & 1844 & \\
\hline \multirow{4}{*}{200} & K 9-5 & 1321 & 1403 & 1932 & 1910 & \multirow{4}{*}{1556} \\
\hline & K 9-6 & 1312 & 1229 & 1890 & 1728 & \\
\hline & K 9-7 & 1258 & 1063 & 1836 & 1850 & \\
\hline & K 9-8 & 1254 & 1257 & 1886 & 1763 & \\
\hline \multirow{5}{*}{300} & K13 & 1230 & 1106 & 1694 & 1753 & \multirow{5}{*}{1527} \\
\hline & $\mathrm{K} 13-1$ & 1360 & 1200 & 1872 & 1704 & \\
\hline & $\mathrm{K} 13-2$ & 1325 & 1355 & 1935 & 1968 & \\
\hline & K13-3 & 1205 & $123 t$ & 1814 & 1751 & \\
\hline & $\mathrm{K} 13-4$ & 1246 & 1138 & 1755 & 1898 & \\
\hline
\end{tabular}

Observation on the cured tobacco. Just as in the previous series, the tobacco of the 40-pounds-potash plots in the sheds failed to come into case during damps as soon as the other plots.

Yield of leaf. Total yield of cured leaves for these plots during four years is presented in Table 16. Here again the depressing influence of the very wet years of 1927 and 1928 is striking. Replications of the same treatment show considerable variation, 
but judging from the averages, it seems that 40 pounds of potash is not sufficient to keep up the yield. The highest average yield was on the plots that received an application of 100 pounds of potash. The yield was reduced somewhat by increasing this application to 200 pounds and there was further reduction of yield when it was increased to 300 pounds.

Table 17. Grade Indexes of Tobacco from the Plots in the QuantitatIVE SERIES OF 1927

\begin{tabular}{|c|c|c|c|c|c|c|}
\hline \multirow{2}{*}{$\begin{array}{l}\text { Potash } \\
\text { lbs, per acre }\end{array}$} & \multirow{2}{*}{ Plot No. } & \multicolumn{4}{|c|}{ Index } & \multirow{2}{*}{ Average } \\
\hline & & 1927 & 1928 & 1930 & 1931 & \\
\hline \multirow{5}{*}{40} & $\mathrm{~K} 11-2$ & .397 & .365 & .436 & .387 & \multirow{5}{*}{.368} \\
\hline & K11-3 & .401 & .395 & .374 & .366 & \\
\hline & K11-4 & .304 & .351 & .327 & .354 & \\
\hline & K11-5 & .345 & .337 & .345 & .349 & \\
\hline & K11-6 & .399 & .368 & .388 & .375 & \\
\hline \multirow{3}{*}{100} & $\mathrm{~K} 12-2$ & .381 & .425 & .452 & .426 & \multirow{3}{*}{.415} \\
\hline & K12-3 & .418 & .478 & .417 & .447 & \\
\hline & $\mathrm{K} 12-4$ & .358 & .346 & .411 & .420 & \\
\hline \multirow{4}{*}{200} & K 9-5 & .377 & .472 & .459 & .438 & \multirow{4}{*}{.428} \\
\hline & K 9-6 & .364 & .449 & .465 & .434 & \\
\hline & K 9-7 & .358 & .394 & .403 & .440 & \\
\hline & K 9-8 & .397 & .518 & .450 & .437 & \\
\hline \multirow{5}{*}{300} & $\mathrm{~K} 13$ & .391 & .464 & .500 & .465 & \multirow{5}{*}{.438} \\
\hline & K13-1 & .412 & .498 & .446 & .447 & \\
\hline & K13-2 & .423 & .409 & .448 & .447 & \\
\hline & K13-3 & .405 & .449 & .454 & .425 & \\
\hline & K13-4 & .354 & .412 & .425 & .496 & \\
\hline
\end{tabular}

Effect on the grading. Just as in the other series, the effect of lowering the potash application was much more serious on the quality of the crop than on the quantity. Table 17 summarizes the grade indexes of the crops for four years.

A decided reduction in quality occurred where the potash was lowered to 40 pounds, the cured leaves being short, thick, dry and non-elastic. The tobacco on the 100-pounds-potash plots was much better, but still inferior to that of the 200 and 300 -pound plots. The 300-pounds gave a somewhat higher index than the 200pound plots. 


\section{Influence of the Quantity of Potash on the Fire- Holding Capacity}

Samples of four grades of each crop were fermented, aged throughout the summer, and tested for fire-holding capacity the following autumn. The results of these tests are given in full in the annual reports. A summary of all tests for the years 1926-28 on the old quantitative series is presented in Table 18 and will suffice to show how the fire-holding capacity drops off with the decrease in fertilizer potash. The tests were made by igniting leaves with an incandescent electric filament and recording the number of seconds elapsing before the spreading glow stopped.

These data show that the fire-holding capacity grows less every year on the 40-pounds-potash plots. For the first year, the decline

Table 18. Summary of Fire-holding Capacity Tests on Crops of 1926-28. Old Quantitative Series of 1926

\begin{tabular}{r|c|c|c|c}
\hline \multirow{2}{*}{ Quantity of potash } & \multicolumn{3}{|c|}{ Average burn (seconds) of crop } \\
\cline { 2 - 4 } & 1926 & 1927 & 1928 & All \\
\hline 40 lbs. per acre & 39 & 36 & 21 & 32 \\
100 lbs. per acre & 40 & 57 & 41 & 46 \\
200 lbs. per acre & 45 & 56 & 51 & 51 \\
\hline
\end{tabular}

was hardly noticeable; it was well apparent the second year and still more so the third. On the plots that had 100 pounds potash to the acre, there was no ill effect on the fire-holding capacity the first two years, but a decided drop in the third. The burn was maintained throughout on the 200-pound plots. In making these tests, it was observed that the ash on the 40-pounds-potash plots was whiter than on the others. This was probably due to the increase of calcium and magnesium in the leaf when the potash content was reduced.

Tests made on the tobacco from the other series of plots confirm those reported on this series and also show that the fire-holding capacity is not increased when the fertilizer application is raised to 300 pounds potash per acre.

Results of a series of tests on leaves grown in the greenhouse are graphically presented in Figure 18 and support the conclusions drawn from the field grown leaves. 


\section{Effect of the Quantity of Potash Applied in the Fertilizer on} the Percentage of Potash, Lime and Magnesia

\section{in the Leaf}

On a previous page it has been stated that with decreasing amounts of potash applied in the fertilizer, not only is the percentage of potash absorbed by the leaf reduced, but also there is a corresponding increase in the other mineral bases. In order to see to what extent these changes had occurred, samples of darks and seconds of the crop of 1928 were analyzed for bases after the tobacco had been fermented and aged for a year. Results of these analyses (air dry basis) are presented in Tables 19 and 20.

Table 19. Percentage of Potash, Lime and Magnesia in Cured Leaves. Quantitative Potash Series of 1926. Crop of 1928, the Third on These Plots

\begin{tabular}{c|c|c|c}
\hline \hline \multirow{2}{*}{$\begin{array}{c}\text { Lbs. potash per acre } \\
\text { in the fertilizer }\end{array}$} & \multicolumn{3}{|c}{ Percentage in the leaf } \\
\cline { 2 - 4 } & Potash $\left(\mathrm{K}_{2} \mathrm{O}\right)$ & Lime $(\mathrm{CaO})$ & Magnesia $(\mathrm{MgO})$ \\
\hline 40 & 4.07 & 8.17 & .94 \\
100 & 5.55 & 6.71 & .62 \\
200 & 6.69 & 5.87 & .69 \\
\hline
\end{tabular}

Table 20. Percentage of Potash, Lime and Magnesia in Cured Leaves. Quantitative Potash Series of 1927. Crop of 1928, the

Second on These Plots

\begin{tabular}{c|c|c|c}
\hline \hline \multirow{2}{*}{$\begin{array}{c}\text { Lbs. potash per acre } \\
\text { in the fertilizer }\end{array}$} & \multicolumn{3}{|c}{ Percentage in the leaf } \\
\cline { 2 - 3 } & Potash $\left(\mathrm{K}_{2} \mathrm{O}\right)$ & Lime $(\mathrm{CaO})$ & Magnesia $(\mathrm{MgO})$ \\
\cline { 2 - 3 } 40 & 5.95 & 7.56 & .93 \\
100 & 6.98 & 6.73 & .79 \\
200 & 7.97 & 6.25 & .80 \\
300 & 8.21 & 6.00 & .74 \\
\hline
\end{tabular}

The potash analyses on the older (1926) series for four years are also shown in Table 21.

From an inspection of the data presented in these tables we may draw the following conclusions:

1. Each increase in the quantity of potash applied in the fertilizer, up to 300 pounds potash per acre, increased the percentage of potash in the leaves. 
2. Where only 40 pounds of potash was applied annually, the percentage in the leaves declined throughout the five years of this test at a fairly uniform rate.

3. When 100 pounds was applied there was also a decline, but at a slower rate and it was uniform after the second year.

4. With 200 pounds of potash in the fertilizer, the percentage was maintained at a high level except for an unaccountable drop in 1928.

5. The lower amount of potash in the seconds than in the darks on the limed plots and also on the unlimed 40-pound plot in the 1931 crop, indicates that the supply is so low on these plots that

Table 21. Percentage of Potash in Leaves from Old Quantitative Series of 1926. All Figures Calculated to Moisture Free Basis ${ }^{1}$

\begin{tabular}{|c|c|c|c|c|c|c|c|c|c|c|}
\hline \multirow{3}{*}{$\begin{array}{l}\text { Potash in } \\
\text { fertilizer, } \\
\text { lbs. per A. }\end{array}$} & \multirow{3}{*}{\multicolumn{2}{|c|}{$\begin{array}{l}\text { Plot No. } \\
\text { and } \\
\text { grade }\end{array}$}} & \multicolumn{8}{|c|}{ Percentage $\mathrm{K}_{2} \mathrm{O}$ in leaves } \\
\hline & & & \multicolumn{2}{|c|}{1926} & \multicolumn{2}{|c|}{1927} & \multicolumn{2}{|c|}{1928} & \multicolumn{2}{|c|}{1931} \\
\hline & & & Plot & Avge. & Plot & Avge. & Plot & Avge. & Plot & Avge. \\
\hline \multirow{4}{*}{40} & K11 & $\mathrm{S}$ & 6.94 & \multirow{4}{*}{7.00} & 5.12 & \multirow{4}{*}{5.93} & 3.84 & \multirow{4}{*}{4.39} & $2.27^{3}$ & \multirow{4}{*}{3.19} \\
\hline & K11 & $\mathrm{D}$ & 6.67 & & 5.93 & & 3.90 & & $3.50^{3}$ & \\
\hline & $\mathrm{K} 11-1$ & $S$ & 7.12 & & 6.16 & & 5.40 & & 2.55 & \\
\hline & $\mathrm{K} 11-1$ & D & 7.75 & & 6.52 & & 4.42 & & 4.43 & \\
\hline \multirow{4}{*}{100} & $\mathrm{~K} 12$ & $\mathrm{~S}$ & 6.69 & \multirow{4}{*}{7.26} & 7.80 & \multirow{4}{*}{7.58} & 6.24 & \multirow{4}{*}{5.98} & 4.73 & \multirow{4}{*}{4.01} \\
\hline & $\mathrm{K} 12$ & $\mathrm{D}$ & 6.62 & & 7.81 & & 6.17 & & 4.62 & \\
\hline & $\mathrm{K} 12-1$ & S & 7.97 & & 7.15 & & 5.74 & & $2.50^{3}$ & \\
\hline & $\mathrm{K} 12-1$ & $\mathrm{D}$ & 7.77 & & 7.56 & & 5.77 & & $4.20^{3}$ & \\
\hline \multirow{4}{*}{200} & K 9 & S & 8.00 & \multirow{4}{*}{8.14} & 8.66 & \multirow{4}{*}{8.31} & 7.60 & \multirow{4}{*}{7.24} & 7.84 & \multirow{4}{*}{$8.03^{2}$} \\
\hline & K 9 & D & 7.48 & & 8.36 & & 6.76 & & 8.30 & \\
\hline & K 9-1 & $S$ & 8.64 & & 7.72 & & 7.28 & & 8.00 & \\
\hline & K 9-1 & D & 8.45 & & 8.49 & & 7.30 & & 7.96 & \\
\hline
\end{tabular}

it is being translocated from the older leaves (seconds) and reutilized in the younger growing leaves (darks). When there is an abundant supply of potash, the seconds normally contained a somewhat higher content than the darks $(4: 44)$.

6. The percentage of calcium varies inversely with the potassium. This is in accord with all our previous results.

7. That the magnesium does not show so distinctly the same inverse relationship to potassium in these tables is without doubt

\footnotetext{
${ }^{1}$ In our report for 1930 , Table 16, all percentages in this test were stated to be on air dry basis. This was true of all except the 1926 samples, which by mistake were published on a moisture free hasis.

${ }^{2}$ In 1931 , the $\mathrm{K} 9$ and $\mathrm{K} 9-1$ plots had been discontinued. The percentages reported here are for plots $\mathrm{N} 11$ and N14, which also received the annual application of 200 pounds potash and were adjacent to the other plots.

${ }^{8}$ Limed in 1931.
} 
due to the very low supply of this element in the soil of these plots during the wet year of 1928 . That such a relation does normally exist has been fully established by several other experiments on these fields.

\section{Discussion of Results of Field Tests}

The object of these tests was to answer the question: What quantity of total potash $\left(\mathrm{K}_{2} \mathrm{O}\right)$ should the grower apply annually to produce optimum quality and quantity of tobacco? To what extent has this question been answered by these tests?

It is apparent in the first place that 40 pounds of potash to the acre is not enough. It not only produces harsh, dry, non-elastic, thick, and inferior leaves, but also it reduces seriously the fireholding capacity and does not maintain the yield.

When the application was increased to 100 pounds (on old tobacco land), the ill effects on the quality were not apparent at once, but after a year or two it was found that this application was not enough to maintain the quality. On the lighter land, this amount did not quite maintain the yield, but on the better soil it gave the highest yield of all.

At the rate of 200 pounds per acre on the lighter soil, both the quality and yield were maximum. On the heavier soil, the yield was not quite as high as for the 100 pounds application, while the grading was not quite as good as for the 300 pounds application.

At the 300 pounds rate the quality was somewhat higher than the 200 pounds rate, but there was a further falling off in pounds of leaf per acre. The fire-holding capacity was about the same as for the 200 pounds application.

The average yields presented in the tables indicate that there is an optimum point beyond which each increase of potash applied in the fertilizer will result in a further decline in yield. No adequate explanation of such a decline is at hand. As previously mentioned, Dr. Jenkins also found that the yield was increased by reducing the fertilizer potash from 350 down to 150 pounds. The decline in our experiments has been small-possibly not significant -and probably is not a sufficient basis for drawing conclusions as to the danger of applying too much potash.

In view of all these considerations, it seems that an application of about 200 pounds of potash to the acre is the safest practice. If sufficient plots had been available to extend these tests by using quantities differing only by intervals of 25 or 50 pounds, the results might have shown the optimum to be somewhat lower or higher than 200 pounds. Since Connecticut Valley fields must necessarily differ somewhat as to their potash requirement, it was not thought profitable to determine more closely the optimum application for this particular soil at the Tobacco Substation. 


\section{COMPARISON OF POTASH-CONTAINING FERTILIZER MATERIALS}

There is a considerable number of mineral and organic materials that may be added to the fertilizer mixture or applied directly to the soil to furnish adequate potash for the tobacco crop. The grower who mixes his own fertilizer or the manufacturer of mixed goods is confronted with the problem of deciding which one or which combination of several he will use. If they are all equally efficient in the quantity and quality of tobacco that they will produce his choice will be governed by price, suitability for mixing with other ingredients, or ease of application. If, however, certain potash-containing materials produce tobacco of different quality from that secured by the use of other materials or if one material is capable of increasing the yield more than another, he must be guided by that which experiment or past experience has shown to be the relative crop producing value of the different carrier materials.

In choosing a fertilizer, it is not safe to base the decision on theoretical reasons alone, although these are always helpful. On the other side, it may be just as unwise to base the decision on so-called experience. For example, a grower uses fertilizer A one year and $\mathrm{B}$ the next year and if he gets better tobacco the second year, he concludes that fertilizer $\mathrm{B}$ is better. Or he uses $\mathrm{A}$ on one field and $\mathrm{B}$ on the other. Conclusions drawn from such comparisons are worthless because there are so many influencing differences other than the fertilizer. It is only when we compare two fertilizer mixtures, differing only in the form of potash material they contain, on small adjacent plots in the same field, the same year, with several replications and continue this through more than one year that we are safe in drawing any conclusion as to the relative value of those two materials. Then, however, we are basing our decision on experiment rather than experience. Each one of the potash-containing materials has its staunch advocates who ascribe to it superior virtues in producing quality or yield.

It has been with the object of subjecting the various materials to such rigid experimentation, that several series of field experiments have been conducted on the Experiment Station farm during the last 10 years. These will be discussed after we have briefly described the materials available.

\section{Fertilizer Materials Containing Potash}

The materials commonly used to supply potash in fertilizer mixtures for use on tobacco land in the Connecticut Valley, are sulfate of potash, nitrate of potash, carbonate of potash, sulfate of potashmagnesia (double manure salts), cottonhull ashes, and tobacco stems. Wood ashes are sometimes used for this purpose, but rarely 
mixed with the fertilizer. Stems also are applied to the land separately unless they are finely ground, in which case they may be mixed with the other ingredients. Considerable quantities of potash may be added in organic materials which are applied mainly to furnish nitrogen. Such are manure, cottonseed meal, castor pomace and linseed meal.

In Table 22 we present a list of the fertilizer materials containing potash commonly used here, with average analyses of their content of potash and other elements that may influence their selection for use on the tobacco crop. Muriate of potash or other materials containing considerable quantities of chloride should never be used in tobacco mixtures (see p. 170).

Sulfate of potash. This form which is used probably more than any other in tobacco fertilizers, is imported from Germany and France. In the neighborhood of Stassfurt there are enormous deposits of sulfates and chlorides of potassium, sodium, magnesium and calcium, 50 to 150 feet thick, and hundreds of feet below the surface of the ground. These crude salts known as carnallit, kainit, manure salts, and so forth, are mined and may be used directly as fertilizers, but for economy of transportation and use they are mostly refined and separated into a number of more or less pure salts. One of the most common of these is our commercial sulfate of potash containing about 48 per cent $\mathrm{K}_{2} \mathrm{O}$. It is one of the least expensive of the potash salts. The only objection that has been raised is that its use may increase the sulfate content of the tobacco leaf.

Double sulfate of potash-magnesia. This is another product of refinement of the Stassfurt salts. It has the advantage of containing magnesia, which is so essential in tobacco culture. Its disadvantages are first, that it contains only about one half as much potash as the high grade sulfate and, second, that it contains twice as much sulfate in proportion to the potash supplied. It is somewhat more expensive per unit of potash.

Carbonate of potash-magnesia. This came also from Germany and was once strongly advocated for use on tobacco. Theoretically, it should be well adapted to tobacco growing, since it contains the two most.important bases and has no sulfate. The writers know of no field experiments, however, in which its worth was tested. It has now practically disappeared from the market.

Carbonate of potash. This is also imported from Germany. It contains about 64 per cent $\mathrm{K}_{2} \mathrm{O}$ and is the most expensive, but at the same time the most concentrated, of the potash salts. It is not a direct product of the mines, but is prepared by heating muriate of potash with carbonate of magnesia, carbon dioxide, and water under pressure and fractionating the resulting mixed carbonate. 


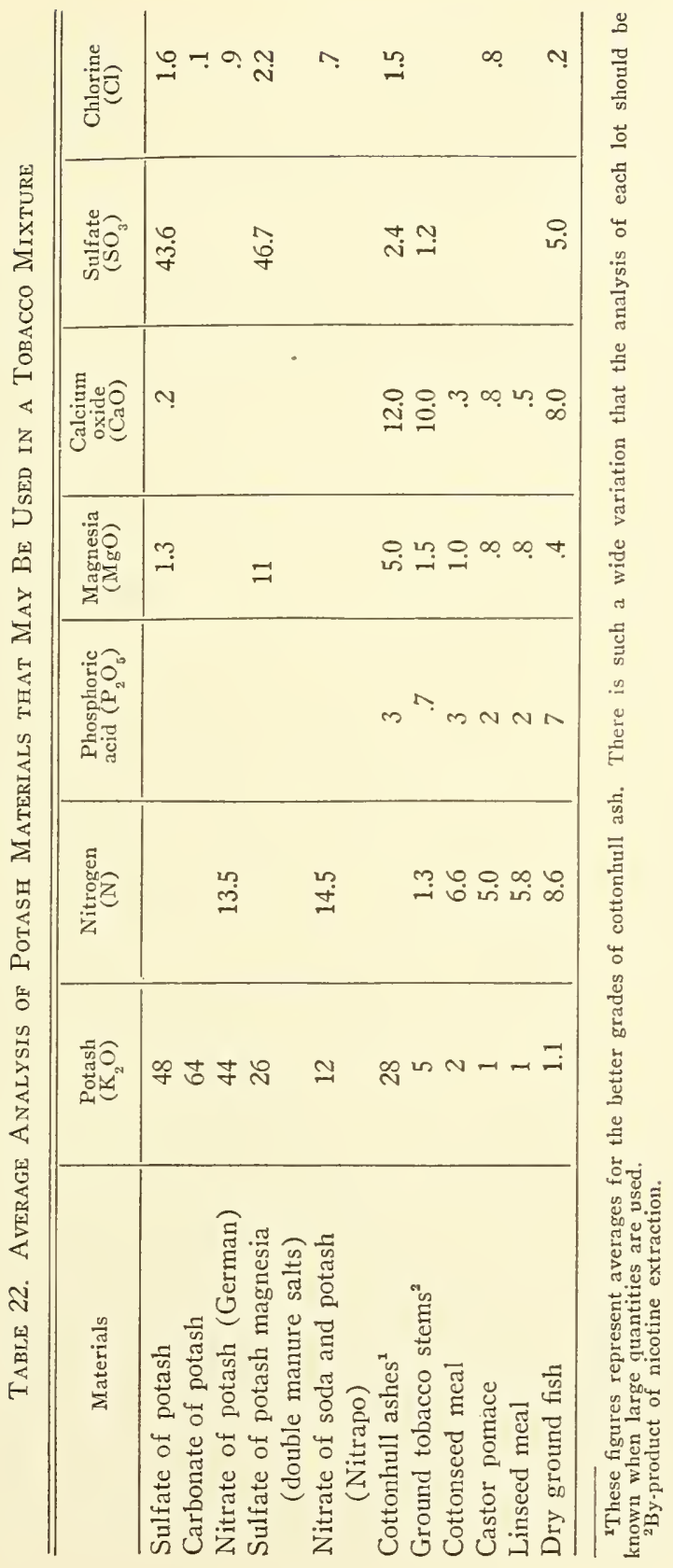


Only a trace of the chloride appears in the final product. This is a fine white granular material, but it becomes "lumpy" when exposed, because of its property of absorbing moisture from the air. Therefore it should be mixed at once after opening the container. When mixed with considerable quantities of cottonseed meal or other conditioning material, there is no danger of "lumping:"

Wood ashes. This carrier contains carbonate of potash, and has been used to some extent for tobacco, particularly Canada hardwood ashes. The supply, however, is limited and uncertain. Also the percentage of potash varies greatly, depending on the kind of wood burned, locality, and exposure to leaching by rain. On the average, they contain about 5 per cent of potash but may be as low as 1 per cent, or as high as 8 or 10 per cent. They also contain 2 per cent of phosphoric acid, and calcium and magnesium carbonates in varying amounts up to 40 per cent. Naturally all of these carbonates are alkaline and the use of large amounts of wood ashes involves the danger of making the land so alkaline that black rootrot of tobacco becomes serious.

Cottonhull ashes. This is produced by the burning of cottonseed hulls and bolls in the South, and contains potash in the form of carbonate. According to average analyses published in our report for 1930, page 367, they contained about 26 per cent $\mathrm{K}_{2} \mathrm{O}$. 3 per cent $\mathrm{P}_{2} \mathrm{O}_{5}, 12$ per cent $\mathrm{CaO}, 5$ per cent $\mathrm{MgO}$ and 1.5 per cent $\mathrm{Cl}$. Cottonhull ashes were a favorite source of potash for tobacco a generation ago and there has been a marked revival of their use in the Connecticut Valley within the last few years.

Nitrate of potash. This material (commercially known as saltpetre) was formerly very expensive, being derived mostly from caves or gathered in India (Calcutta potash) by very laborious processes. Its high price was also enhanced by its extensive use in the manufacturing industries. After the more recent development of air nitrogen fixation processes, however, its synthetic manufacture was perfected and now it is one of the least expensive of the potash materials, when allowance is made for the value of the nitrogen in the compound. The supply is unlimited. It has the great advantage over most of the other potash salts of containing only nutrient materials that the tobacco plant needs. That is, there are no residues to accumulate or produce undesirable changes in the soil or to be absorbed with injurious effect by the plant. It is hygroscopic and becomes "sticky" or "lumpy" when exposed too long to the air before mixing.

Nitrapo. This material, which is sold under the trade name, Nitrapo, is a mixture of nitrate of soda and nitrate of potash containing about 12 per cent of potash, and comes from the same 
deposits in Chile from which the more common Chilean nitrate of soda is derived. It is also hygroscopic.

Tobacco stems. These are the midribs of tobacco leaves, which are taken out before the leaf can be made into cigars, cigarettes or chewing tobacco. They average about 5 per cent $\mathrm{K}_{2} \mathrm{O}$, varying with the region where the tobacco was grown. Connecticut Valley stems often analyze as high as 8 or 9 per cent $\mathrm{K}_{2} \mathrm{O}$. "Long stems" are merely baled at the factory, shipped to the fields and spread with a pitch fork. The percentage of water in them is extremely variable. The writers analyzed stems as they were leaving the factory and found 34 per cent water in them. Most of the ground stems on the market are the finely ground residue that remains after the extraction of nicotine for insecticide. Since this extraction is done with steam, the stems are incidentally sterilized. Therefore using them involves no danger of carrying diseases. Their finely ground condition also makes them ideal for mixing with the other ingredients and they serve as a conditioning or drying agent. Theoretically, stems should be an ideal fertilizer, since it is safe to assume that they contain all the elements required by the growing tobacco plant. Only nitrogen need be added to stems to make a complete fertilizer for tobacco. The potash in stems is completely soluble and available.

Organic materials. Potash in cottonseed meal, castor pomace. manure, and so forth, is completely water soluble and has the same degree of availability for the use of the plant as other potash salts.

Availability. There is no evidence to indicate that any problem exists with respect to availability of the potash in any of the potash carriers discussed here, that is, potash in any of them is completely available (unlike the phosphorus problem). Whatever differences may be obtained in growth or quality of tobacco through the use of different potash carriers must be ascribed to the influence of the other elements in the particular carrier under consideration. and not to the degree of availability of the potash. It must not be assumed, however, that the other elements carried along by the potash will be absorbed by the plant in the same proportion in which they are added to the soil, or that they will be taken up at all. It has been explained in a previous section (page 146) that potassium forms new combinations as soon as it enters the soil and that the plant derives its potash from the new combination regardless of the original potash combination in the fertilizer. 


\section{Field Tests of Potash Carriers}

Five series of plots have been used in comparing the different potash materials. Since these series have been conducted at different times and on different fields, each will be discussed separately before summarizing the results. These series are designated as follows:

Series I. Comparison of sulfate, carbonate and nitrate of potash (old series of 1925).

Series II. Comparison of sulfate, carbonate and nitrate of potash (new series of 1927).

Series III. Comparison of double sulfate of potash-magnesia with high grade sulfate.

Series IV. Comparison of tobacco stems with mineral materials.

Series V. Comparison of cottonhull ashes with other materials.

The tobacco grown on the different fertilizers was compared in the following ways:

1. Total weight of cured tobacco.

2. Percentage of grades (expressed in this bulletin in one figure as "grade index").

3. Quality of leaves at time of sorting-color, shape, vein, elasticity, and so forth.

4. Quality after fermenting and ageing for a year.

5. Fire-holding capacity of fermented leaves, as measured by strip test.

6. Smoking qualities, judged from cigars on which the leaves were used.

Comparisons of growth in the field were also made but throughout these series no consistent differences in character or amount of growth were observed that could be ascribed to the potash materials.

For a progressive description of these experiments and detailed tabulation of results, the reader is referred to the Annual Reports of the Station from 1925 to 1930. In the present Bulletin it has seemed sufficient to present only summary tables with final discussion and conclusions.

\section{Series I. Comparison of Sulfate, Carbonate and Nitrate of Potash. Old Series of 1925}

This series consisted of 10 one-fortieth acre plots on Field V, a light, sandy soil, more fully described on page 174 of this Bulletin. Five different fertilizer treatments were applied on duplicate plots, and the series was continued on the same plots for six years. It was the purpose to compare not only each of the three different 
carriers used separately, but also different combinations of the carriers. The quantity of potash (200 pounds), nitrogen (200 pounds), phosphoric acid (160 pounds), and magnesia (15 pounds) was the same in all treatments, the only differences in any of them being in the materials used to supply potash. The composition of the formulas was as shown in Table 23 during the last two years of the experiment.

Table 23. Composition of the Fertilizer Mixtures Used in Plots of SERIES I AND II. 1929-3I

\begin{tabular}{l|c|c|c|c|c|c|c}
\hline \hline $\begin{array}{c}\text { Plot numbers and } \\
\text { distinctive treat- } \\
\text { ment }\end{array}$ & \multicolumn{5}{|c|}{ Pounds of fertilizer material per acre } \\
\cline { 2 - 7 } & $\begin{array}{c}\text { Cotton- } \\
\text { seed } \\
\text { meal }\end{array}$ & $\begin{array}{c}\text { Castor } \\
\text { pomace }\end{array}$ & $\begin{array}{c}\text { Nitrate } \\
\text { of } \\
\text { soda }\end{array}$ & $\begin{array}{c}\text { Precipi. } \\
\text { tated } \\
\text { bone }\end{array}$ & $\begin{array}{c}\text { Potash carrier } \\
\text { Sulfate }\end{array}$ & $\begin{array}{c}\text { Carbon- } \\
\text { ate }\end{array}$ & Nitrate \\
\hline $\begin{array}{l}\text { K1. All mineral } \\
\text { potash as sulfate }\end{array}$ & 1765 & 741 & 260 & 250 & 327 & - & - \\
$\begin{array}{l}\text { K5. All mineral } \\
\text { potash as carbonate }\end{array}$ & 1765 & 741 & 260 & 250 & - & 245 & - \\
$\begin{array}{l}\text { K7. Mineral potash } \\
\text { in nitrate. }\end{array}$ & 1765 & 741 & - & 250 & - & 22 & 325 \\
$\begin{array}{l}\text { K8. 1/2 in carbonate } \\
\text { 1/2 in sulfate }\end{array}$ & 1765 & 741 & 260 & 250 & 163 & 123 & - \\
$\begin{array}{l}\text { K9. I/3 in sulfate } \\
\text { 1/3 in carbonate } \\
\text { 1/3 in nitrate }\end{array}$ & 1765 & 741 & 165 & 250 & 109 & 82 & 119 \\
\hline
\end{tabular}

During the preceding years, the quantity of nitrogen applied was reduced to 164 pounds per acre (see Tob. Sta. Bul. 6, p. 27, for formulas). The precipitated bone was also omitted from the formulas in 1926, 1927 and 1931.

Soon after the experiment was started, it was found that two of the plots (K1-2 and K5) at one corner of the field were on soil of higher reaction and not so favorable to growth of tobacco. These two plots lagged behind the others, both in yield and quality, throughout the experiment.

\footnotetext{
In this formula a small quantity of the potash (less than one-tenth) was in carbonate. This substitution was made to avoid increasing the nitrate nitrogen to more than one-fifth of the total nitrogen. In the earlier years when the nitrogen ratio was not so high, carbonate was used to supply one-third of the potash.
} 


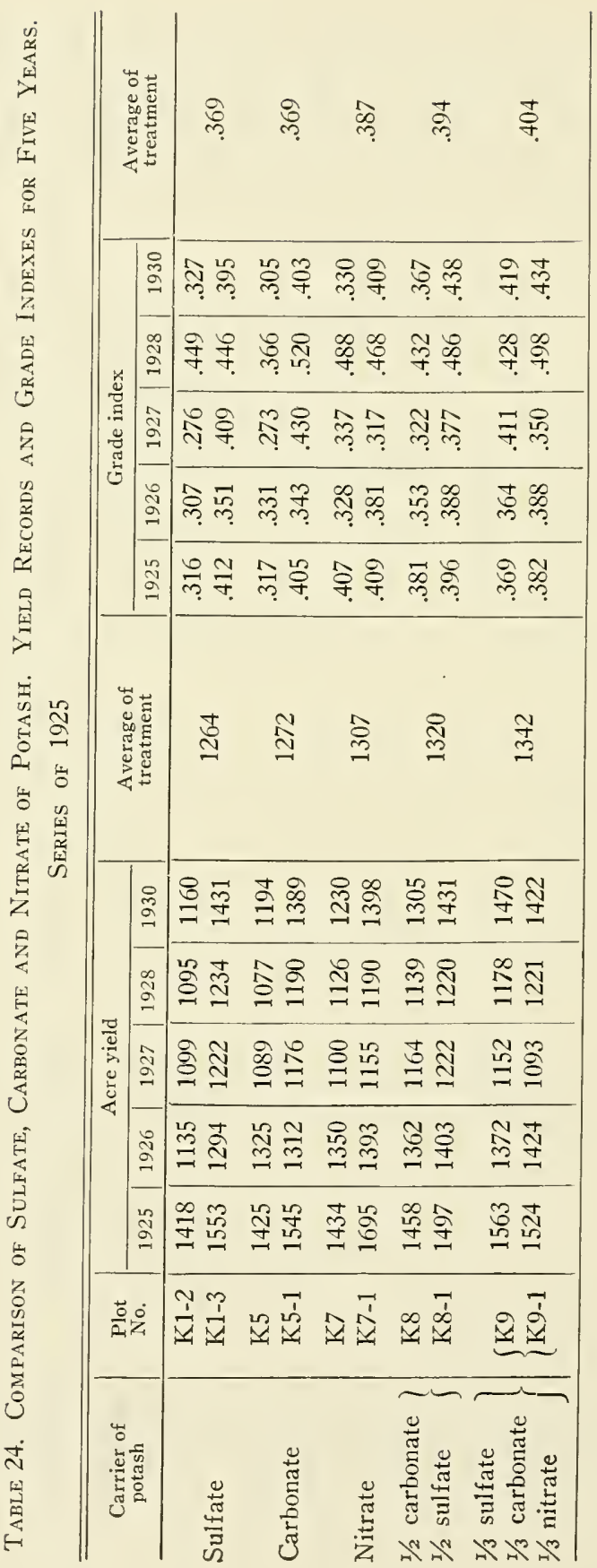


The yield and grade indexes of the tobacco grown on these plots for five years are presented in Table 24. These show a slight advantage in favor of the triple source of potash. However, when it is recalled that the poor plots K1-2 and K5 on the west end make this row of questionable value and we compare only the plots on the east end with each other (Table 25), it will be seen that the

Table 25. Comparison of Sulfate, Carbonate and Nitrate of Potash. Average Yields and Grade Indexes for Five Plots on East End For Five Years. Series of 1925

\begin{tabular}{l|c|c}
\hline \multicolumn{1}{c|}{ Carrier } & $\begin{array}{c}\text { Average } \\
\text { yield for 5 years }\end{array}$ & $\begin{array}{c}\text { Average grade } \\
\text { index for 5 years }\end{array}$ \\
\hline Sulfate & 1347 & .403 \\
Carbonate & 1323 & .420 \\
$\begin{array}{l}\text { Nitrate } \\
\left.\begin{array}{l}1 / 2 \text { carbonate } \\
1 / 2 \text { sulfate }\end{array}\right\}\end{array}$ & 1366 & .397 \\
$\left.\begin{array}{l}1 / 3 \text { sulfate } \\
1 / 3 \text { carbonate } \\
1 / 3 \text { nitrate }\end{array}\right\}$ & 1355 & .417 \\
\hline
\end{tabular}

differences both in yield and grade index are quite small, not sufficiently large to be of significance.

The results indicate that, as far as yield and grading are concerned, it makes little difference which carrier or combination of carriers is used. The carbonate plots have a little higher index but a lower acre yield than the others.

\section{Series II. Comparison of Sulfate, Carbonate, and Nitrate of Potash. New Series of 1927}

Since the growth of tobacco on Field V, where the previous series was located, was not usually as favorable (especially on the two plots mentioned above) as might be wished, and since positive results can be obtained more quickly and with more certainty by using a larger number of replications, the experiment was enlarged in 1927 by repeating the same treatments in triplicate on Field I. The soil here is a sandy loam with a tighter subsoil, not subject to rapid leaching, and always produces a better crop. Because of its acidity, this soil was limed as mentioned on page 178 of this Bulletin; otherwise, the treatment of the two series was the same. The yields for four years are presented in Table 26 and the grade indexes for the same years in Table 27. 
When the results of the four years are averaged, the differences in yield or grading are remarkably small. The only difference that could possibly be considered large enough to be significant is the smaller yield and somewhat higher index of the carbonate plots. This tendency of the carbonate plots has been observed throughout both of these series and frequently commented on in our previous reports. Whether the somewhat better grading is of sufficient advantage to counterbalance the smaller yield and higher cost of carbonate is a question that the grower must decide for himself.

Table 26. Comparison of Sulfate, Carbonate and Nitrate of Potash. Series of 1927. Yield of Cured Leaves for Four Years

\begin{tabular}{|c|c|c|c|c|c|c|}
\hline \multirow{2}{*}{$\begin{array}{l}\text { Source of } \\
\text { potash }\end{array}$} & \multirow{2}{*}{ Plot No. } & \multicolumn{5}{|c|}{ Acre yield } \\
\hline & & 1927 & 1928 & 1930 & 1931 & Average \\
\hline \multirow{4}{*}{ Sulfate } & $\mathrm{K} 1-4$ & 1273 & 1410 & 1846 & 1749 & \multirow{4}{*}{1603} \\
\hline & $\mathrm{K} 1-6$ & 1261 & 1476 & 1884 & 1891 & \\
\hline & $\mathrm{K} 1-7$ & 1258 & 1366 & 2025 & 1766 & \\
\hline & $\mathrm{K} 1-9$ & 1320 & 1442 & 1910 & 1764 & \\
\hline \multirow{3}{*}{ Carbonate } & $\mathrm{K} 5-2$ & 1230 & 1320 & 1826 & 1842 & \multirow{3}{*}{1573} \\
\hline & $\mathrm{K} 5-3$ & 1246 & 1261 & 1838 & 1885 & \\
\hline & $\mathrm{K} 5-4$ & 1307 & 1419 & 1988 & 1713 & \\
\hline \multirow{3}{*}{ Nitrate } & $\mathrm{K} 7-2$ & 1271 & 1394 & 1900 & 1792 & \multirow{3}{*}{1609} \\
\hline & K7-3 & 1250 & 1330 & 1983 & 1900 & \\
\hline & $\mathrm{K} 7-4$ & 1318 & 1416 & 1941 & 1813 & \\
\hline $1 / 2$ carbonate & K8-2 & 1319 & 1331 & 1862 & 1845 & \multirow{3}{*}{1617} \\
\hline \multirow[t]{2}{*}{$1 / 2$ sulfate } & $\mathrm{K} 8-3$ & 1280 & 1391 & 2010 & 1830 & \\
\hline & $\mathrm{K} 8-4$ & 1345 & 1445 & 1936 & 1809 & \\
\hline $1 / 3$ sulfate & K9-2 & 1292 & 1394 & 1762 & 1896 & \multirow{3}{*}{1622} \\
\hline I/3 carbonate & K9-3 & 1319 & 1353 & 1984 & 1927 & \\
\hline $1 / 3$ nitrate & K9-4 & 1284 & 1495 & 1944 & 1813 & \\
\hline
\end{tabular}

Effect on burning qualities of tobacco. Although no very important differences in yield or grading of tobacco from these three potash carriers were found, there still remained the possibility that there might be some superiority of one or the other which would not find expression in the grading. Aside from the grading, it is particularly important that cigar leaf tobacco have good burning qualities. Therefore, after samples from all plots of several years were fermented and aged and were judged at that time to be of about the same quality, they were tested for fire-holding capacity by our usual strip test. 
Table 27. Comparison of Sulfate, Carbonate and Nitrate of Potash. Series of 1927. Grade IndeXes for Four Years

\begin{tabular}{|c|c|c|c|c|c|c|}
\hline \multirow{2}{*}{$\begin{array}{l}\text { Source of } \\
\text { potash }\end{array}$} & \multirow{2}{*}{ Plot No. } & \multicolumn{5}{|c|}{ Grade index } \\
\hline & & 1927 & 1928 & 1930 & 1931 & Average \\
\hline \multirow{4}{*}{ Sulfate } & $\mathrm{K} 1-4$ & .394 & .455 & .486 & .441 & \multirow{4}{*}{.431} \\
\hline & $\mathrm{K} 1-6$ & .372 & .425 & .443 & .439 & \\
\hline & $\mathrm{K} 1-7$ & .413 & .408 & .414 & .454 & \\
\hline & K1-9 & .380 & .420 & .474 & .477 & \\
\hline \multirow{3}{*}{ Carbonate } & $\mathrm{K} 5-2$ & .410 & .431 & 459 & .461 & \multirow{3}{*}{.451} \\
\hline & $\mathrm{K} 5-3$ & .394 & .481 & .488 & .456 & \\
\hline & $\mathrm{K} 5-4$ & .421 & .499 & .467 & .452 & \\
\hline \multirow{3}{*}{ Nitrate } & $\mathrm{K} 7-2$ & .419 & .416 & .506 & .460 & \multirow{3}{*}{.432} \\
\hline & $\mathrm{K} 7-3$ & .380 & .507 & .450 & .458 & \\
\hline & $\mathrm{K} 7-4$ & .326 & .392 & .437 & .436 & \\
\hline $1 / 2$ sulfate & $\mathrm{K} 8-2$ & .396 & .416 & .493 & .457 & \multirow{3}{*}{.436} \\
\hline \multirow[t]{2}{*}{$1 / 2$ carbonate $\}$} & K8-3 & .369 & .389 & .449 & .442 & \\
\hline & $\mathrm{K} 8-4$ & .463 & .458 & .432 & .466 & \\
\hline $1 / 3$ sulfate & $\mathrm{K} 9-2$ & .414 & .385 & .472 & .444 & \multirow{3}{*}{.433} \\
\hline $1 / 3$ carbonate & K9-3 & .365 & .441 & .431 & .440 & \\
\hline $1 / 3$ nitrate & K9-4 & .403 & .452 & .471 & .484 & \\
\hline
\end{tabular}

Table 28. Old Potash Series of 1925 on Field V. Summary of Strip Burn Tests for Four Years

\begin{tabular}{|c|c|c|c|c|c|c|}
\hline \multirow{2}{*}{ Carrier } & \multirow{2}{*}{ Plot } & \multicolumn{5}{|c|}{ Average duration of burn } \\
\hline & & 1925 & 1926 & 1927 & 1928 & Four years 1 \\
\hline Sulfate & $\begin{array}{l}\mathrm{K} 1-2 \\
\mathrm{~K} 1-3\end{array}$ & 36 & 44 & 53 & 48 & 45 \\
\hline Carbonate & $\begin{array}{l}\mathrm{K} 5 \\
\mathrm{~K} 5-1\end{array}$ & 45 & 49 & 56 & 55 & 51 \\
\hline Nitrate & $\begin{array}{l}\mathrm{K} 7 \\
\mathrm{~K} 7-1\end{array}$ & 43 & 41 & 53 & 54 & 48 \\
\hline $\left.\begin{array}{ll}\text { Sulfate } 1 / 2 & \\
\text { Carbonate } 1 / 2\end{array}\right\}$ & $\begin{array}{l}\mathrm{K} 8 \\
\mathrm{~K} 8-1\end{array}$ & 38 & 42 & 55 & 53 & 47 \\
\hline $\left.\begin{array}{l}\text { Sulfate } 1 / 3 \\
\text { Carbonate } 1 / 3 \\
\text { Nitrate } 1 / 3\end{array}\right\}$ & $\begin{array}{l}\text { K9 } \\
\text { K9-1 }\end{array}$ & 43 & 45 & 55 & 51 & 49 \\
\hline
\end{tabular}

${ }^{1}$ Each number in this column is the average of 640 tests. 
Results of the tests on the old series of 1925 for four years are presented in Table 28. The differences in fire-holding capacity are small. It may be significant, however, that during each of the four years the duration of burn for the carbonate plots

Table 29. New Potash Series of 1927 on Field I. Strip Burn Tests FOR CROP OF 1928

\begin{tabular}{|c|c|c|c|c|c|c|c|}
\hline \multirow{2}{*}{$\begin{array}{l}\text { Source of } \\
\text { potash }\end{array}$} & \multirow{2}{*}{ Plot No. } & \multicolumn{4}{|c|}{ Duration of burn in seconds } & \multicolumn{2}{|c|}{ Average } \\
\hline & & Darks & Mediums & Lights & $\overline{\text { Seconds }}$ & Plot & $\begin{array}{l}\text { Treat- } \\
\text { ment }\end{array}$ \\
\hline \multirow{6}{*}{ Sulfate } & K 1-4 & 33 & 45 & 54 & 56 & 47 & \multirow{6}{*}{51} \\
\hline & K $1-5$ & 38 & 44 & - & 49 & 44 & \\
\hline & K 1-6 & 36 & 54 & 58 & 51 & 50 & \\
\hline & K 1-7 & 40 & - & - & 46 & 43 & \\
\hline & K 1-8 & 50 & 59 & 56 & 60 & 56 & \\
\hline & K 1-9 & 60 & 56 & 59 & 57 & 58 & \\
\hline \multirow{4}{*}{ Carbonate } & K 5-2 & 58 & - & 60 & 54 & 57 & \multirow{4}{*}{54} \\
\hline & K $5-3$ & 45 & 59 & 59 & 60 & 56 & \\
\hline & K 5-4 & 45 & 45 & 57 & 54 & 50 & \\
\hline & K 7-2 & 53 & 52 & 49 & 49 & 51 & \\
\hline \multirow[t]{2}{*}{ Nitrate } & K 7-3 & 38 & 56 & 57 & 57 & 52 & \multirow[t]{2}{*}{52} \\
\hline & K $7-4$ & 51 & 52 & - & - & 52 & \\
\hline \multirow{5}{*}{$\left.\begin{array}{l}\text { Sulfate } 1 / 2 \\
\text { Carbonate } 1 / 2\end{array}\right\}$} & K 8-2 & 27 & 48 & 55 & 52 & 46 & \multirow{3}{*}{49} \\
\hline & K 8-3 & 33 & 34 & 52 & 56 & 44 & \\
\hline & K 8-4 & 50 & 58 & 60 & 59 & 57 & \\
\hline & K 9-2 & 55 & 54 & 58 & 54 & 55 & \multirow{7}{*}{52} \\
\hline & K 9-3 & 56 & 54 & 56 & 52 & 54 & \\
\hline Sulfate $1 / 3$ & K 9-4 & 55 & 56 & 59 & 53 & 56 & \\
\hline Carbonate $1 / 3$ & K 9-5 & 34 & 49 & 55 & 52 & 48 & \\
\hline \multirow[t]{3}{*}{ Nitrate $1 / 3$} & K 9-6 & 43 & 58 & 59 & 56 & 54 & \\
\hline & K 9-7 & 53 & 53 & 48 & 49 & 51 & \\
\hline & K 9-8 & 26 & 44 & 48 & 55 & 43 & \\
\hline \multirow{3}{*}{ Stems } & K14 & 54 & 51 & 54 & 52 & 53 & \multirow{3}{*}{53} \\
\hline & K14-1 & 47 & 51 & - & 55 & 51 & \\
\hline & $\mathrm{K} 14-2$ & 54 & 57 & 51 & 56 & 54 & \\
\hline
\end{tabular}

has been somewhat the highest. Also, with one exception, the shortest burn has been on the sulfate plots. Results of the tests on the more recent series of potash plots on Field I, presented in Table 29, are similar to those of the older series. Again carbonate is at the top, but the differences in fire-holding capacity between the 
treatments seem too small to be of significance. Three plots that received all their potash in stems were included in this series. The fire-holding capacity on these was as good as the others.

Summing up all the information we have obtained up to date on fire-holding capacity as measured by the strip test, we may say that the differences produced by use of sulfate, carbonate, nitrate or tobacco stems or various combinations of the above are very small, possibly too small to advise against any one of the potash carriers if it is preferable from the standpoint of price, convenience in mixing, or the like.

Cigars were also made from re-sweat leąves from all of the plots tabulated above. They were thoroughly tested for fire-holding capacity, taste, aroma, closeness of burn, and color of ash. No

Table 30. Old Potash Series of 1925. Percentage of Potash and SUlFur in CROPS OF 1926 ANd 1927

\begin{tabular}{|c|c|c|c|c|c|c|}
\hline \multirow{3}{*}{ Source of potash } & \multicolumn{6}{|c|}{ Percentage (air dry basis) } \\
\hline & \multicolumn{2}{|c|}{ Total sulfur $(\mathrm{S})$} & \multirow{2}{*}{$\begin{array}{c}\text { Sulfate } \\
\text { sulfur (S) } \\
1927\end{array}$} & \multirow{2}{*}{$\mid \begin{array}{c}\text { Organic } \\
\text { sulfur (S) } \\
1927\end{array}$} & \multicolumn{2}{|c|}{ Potash $\left(\mathrm{K}_{2} \mathrm{O}\right)$} \\
\hline & 1926 & 1927 & & & 1926 & 1927 \\
\hline Sulfate & 0.53 & 0.49 & 0.36 & 0.13 & 7.90 & 7.83 \\
\hline Carbonate & 0.43 & 0.42 & 0.28 & 0.14 & 7.56 & 7.60 \\
\hline Nitrate & 0.40 & 0.43 & 0.29 & 0.14 & 7.92 & 7.80 \\
\hline \\
\hline $1 / 2$ carbonate & 0.48 & 0.46 & 0.33 & 0.13 & 7.56 & 7.82 \\
\hline $1 / 3$ sulfate & & & & & & \\
\hline $\begin{array}{l}1 / 3 \text { carbonate } \\
1 / 3 \text { nitrate }\end{array}$ & 0.50 & 0.45 & 0.32 & 0.13 & 7.58 & 7.64 \\
\hline
\end{tabular}

significant or consistent differences in any of the points of judgment were found between the lots of tobacco treated with these potash carriers.

Effect on chemical composition. Two questions occur as to the effect of different potash carriers on the composition of tobacco: First, does the plant absorb more potash from one carrier than from another? Second, is the percentage of sulfur in the leaf increased when sulfate is used in the fertilizer? Samples of darks and seconds from the fermented crop of 1927 were analyzed for sulfur and potash. As far as the amount of potash absorbed is concerned, the data presented in Table 30 show that the differences are very small and not constant. There is no indication that tobacco will actually take up more potash from one carrier than from another. 
The data on sulfur, however, are of more interest and importance. Sulfur occurs in two forms in the tobacco leaf. In the organic form it is a necessary constituent of the protoplasm. In the inorganic form it occurs as sulfate, and if it is combined with potash as a base it is objectionable since it reduces the amount of potash that is free to combine with organic acids. It is therefore important to reduce as much as possible the inorganic or sulfate form. A study of the table shows first of all that the quantity of organic sulfur is remarkably constant (about .13 per cent of the dry weight of the leaf) and does not vary with the source of fertilizer potash. But the sulfate sulfur shows considerable variation, depending on the amount of this element that was applied in the fertilizer. Comparing for example the carbonate plots of 1927 with sulfate plots of the same year, the sulfate sulfur was increased about one-third by application of sulfate of potash in the fertilizer. In other words, any sulfur that is added in the fertilizer will appear only as increased sulfate in the leaf. It is unnecessary in the development of the plant and calls for additional potash in order to keep up the burn. Although a certain small amount (.13 per cent) of sulfur is necessary to the growth of tobacco, there is no need to apply extra sulfur in the fertilizer, since the plant will always be able to satisfy its needs from the soil sulfur or the sulfur that is unavoidably added in the organics of the fertilizer mixture.

The somewhat reduced fire-holding capacity that has been found in the sulfate plots, as compared with the carbonate, is probably due to this small increase in sulfate sulfur. From the standpoint of good combustion it is probably fortunate that the ability of the tobacco plant to absorb increased quantities of sulfur is very limited. None of the analyses that have been made on Connecticut Valley tobacco show a sulfur content as high as 1 per cent, while most of them come close to .5 per cent. In this respect, sulfur is in sharp contrast to chlorine, which the plant may absorb in large amounts, following rather regularly the quantity that has been applied to the soil. ${ }^{1}$ Phosphorus, the third mineral acid element of the plant, acts more like sulfur. In fact, phosphorus is even more constant and it is difficult to change the percentage that occurs in the leaf, no matter how much is applied to the soil.

Other investigators $(6: 213)$ have found that sulfur is absorbed in somewhat larger proportions than our analyses show. Under our conditions it is just as well to avoid the use of excessive amounts of sulfate of potash, but when used in moderate quantities, it seems unlikely that serious injury will ensue from the increased absorption of sulfur.

\footnotetext{
${ }^{1}$ In some Kentucky experiments (Ky. Agr. Expt. Sta. Rpt., 41: 17) the chlorine content of tobacco was raised from .048 per cent in unfertilized tobacco to 6.5 per cent in tobacco where 800 pounds KC1 to the acre were used in the fertilizer.
} 


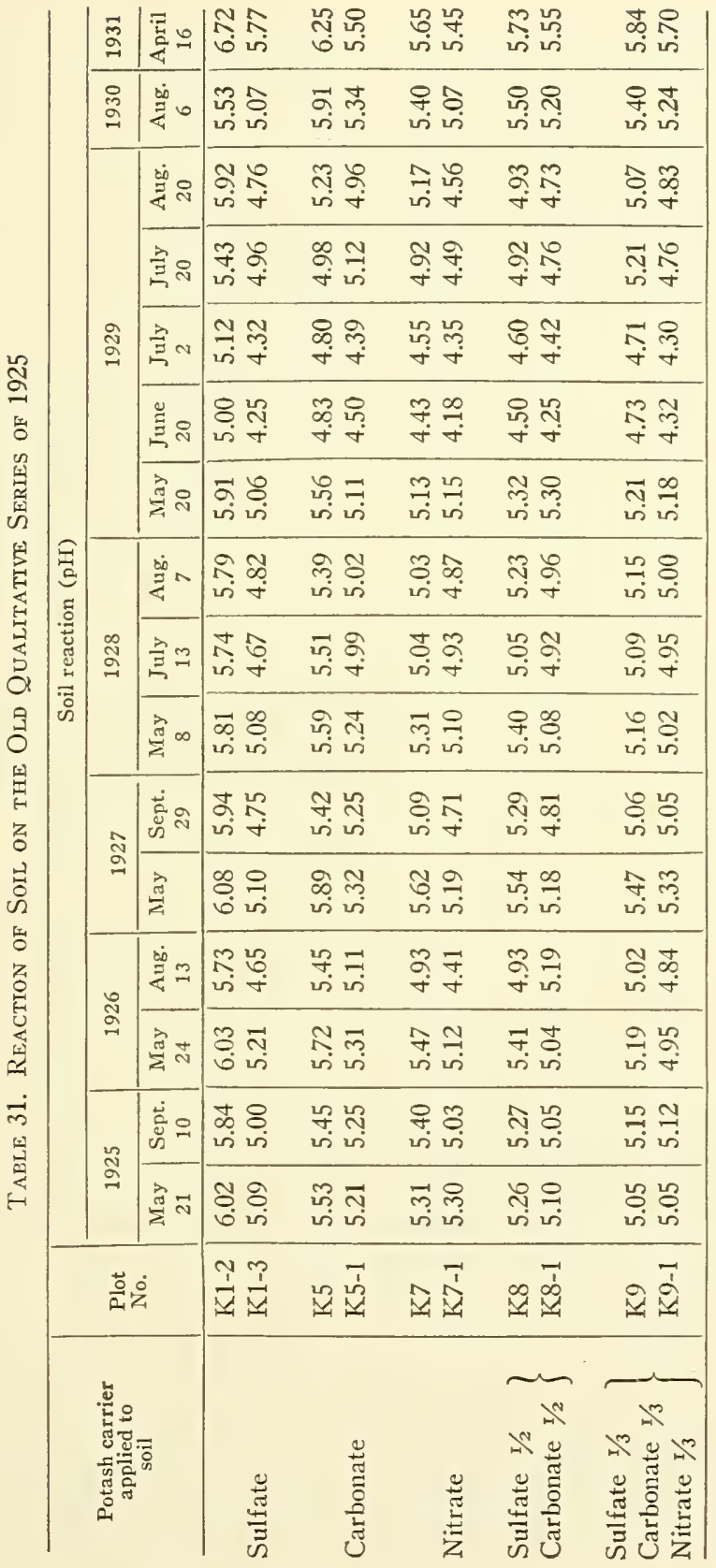


Effect on soil reaction. The importance of maintaining an optimum degree of acidity in the soil has been discussed frequently in the reports and other publications of this Station. A soil may be too acid for best growth of tobacco, due mostly to toxic effects of manganese liberated by such a degree of acidity. On the other hand, if the soil is not acid enough, for example, if it tests higher than $6.00 \mathrm{pH}$, it soon becomes infested with the black rootrot fungus, Thielavia basicola, which reduces the yield of the crop until it becomes unprofitable. If the continuous use of any one potash carrier has the effect of making a soil too acid or not acid enough, then this would be an objection to the use of that carrier. It might be anticipated that carbonate of potash would neutralize the natural soil acids and have a tendency to make the soil alkaline. On the other hand one might expect that the sulfate would make it more acid. Regardless of what might be expected or what has been found in other soils under other crops, the only obvious way of making sure of what would happen under our conditions of culture, soil and practice was to test at various intervals and different times of the year the soil on adjacent plots treated in every way the same except for the source of potash. This was done for six years on the 10 plots of the series of 1925. The first samples were taken before the series was started in the spring of 1925 . The last were taken in 1931 after the experiment was complete. During 1929 the samples were taken at five different times during the growing season to see if there were any temporary or immediate effects of the fertilizer. The tests are recorded in Table 31.

The reactions have varied from year to year and month to month in the same year, a seasonal variation due to weather conditions as fully discussed in a previous report $(6: 264-268)$. All of the plots, however, rise or fall together; there is no definite tendency for any of the plots to become more or less acid than they were when the series was started.

We are warranted in concluding, therefore, that under these conditions of soil, culture and climate, none of these three carriers or combinations of them when used in sufficient quantity to supply 200 pounds of potash to the acre will cause any significant change in the degree of acidity of the soil. Apparently any of them may be used indefinitely in continuous tobacco culture without fear of detrimental results, as far as soil reaction is concerned.

\section{Series III. Comparison of Sulfate of Potash-Magnesia with High Grade Sulfate of Potash}

The first possible benefit to be derived from the substitution of sulfate of potash-magnesia (double manure salts) for the more common sulfate of potash, lies in its content of magnesia, which is essential for the growth of tobacco and without which the plant 
suffers from the malnutrition trouble commonly called sand-drown. Magnesia is also essential to proper combustion, and determines the color of the ash.

This series of field plots was the first potash experiment undertaken at the Station and was repeated on six one-fortieth acre plots on Field I for six years, 1923-1928. The soil here is Merrimac fine sandy loam with some fragments of red sandstone in the surface. It never leaches seriously nor does it suffer excessively in dry weather. It produces a heavier and better crop during a relatively dry year than during a wet one, and is not the type of soil that suffers excessively from sand-drown.

In order to compare the effect of the two carriers of potash, two plots had all of their potash in high grade sulfate, two in double sulfate of potash-magnesia and the other two had the potash derived equally from each source. In all other respects the fertilizer mixture was the same.

The composition of the original mixtures for the plots was as follows :

\begin{tabular}{l|c|c|c}
\hline \hline \multirow{2}{*}{ Fertilizer materials } & \multicolumn{3}{|c}{ Pounds of material applied per acre } \\
\cline { 2 - 3 } & $\begin{array}{c}\text { Plots K1, K1-1. } \\
\text { All potash in } \\
\text { high grade sulfate }\end{array}$ & $\begin{array}{c}\text { Plots K2, K2-1. } \\
\text { All potash in } \\
\text { double sulfate }\end{array}$ & $\begin{array}{c}\text { Plots K3, K3-1. } \\
\text { Potash equally } \\
\text { from each. }\end{array}$ \\
\cline { 2 - 3 } Cottonseed meal & 2100 & 2100 & 2100 \\
Castor pomace & 800 & 800 & 800 \\
Nitrate of soda & 200 & 200 & 200 \\
Precipitated bone & 300 & 300 & 300 \\
Superphosphate & 200 & 200 & 200 \\
Sulfate of potash & 400 & & 200 \\
Double sulfate & & 800 & 400 \\
\hline
\end{tabular}

Each formula supplied about 200 pounds nitrogen, 225 phosphoric acid and 240 pounds potash to the acre and was used during the first two years of the experiment. Beginning with 1925, the quantity of fertilizer was reduced so that the plant food was on the basis of 160-160-200 of nitrogen, phosphoric acid and potash, respectively, and the superphosphate was eliminated. The precipitated bone was also eliminated in 1926 and 1928 .

Field observations throughout the six years of this experiment did not show any difference in growth characteristics between the different treatments, with the exception that for a short time in the very wet season of 1928 , there was some sand-drown on the leaves of the $\mathrm{K} 1$ plots. This disappeared later in the season, and had no effect on the grading. Table 32, showing yields during six years of this experiment, indicates a slight difference, about 1 per cent, in favor of the combination. The grade index for five years (Table 
33), shows a very slightly higher average for the high grade sulfate. None of these differences seem large enough to be significant.

Differences in chemical composition. To see whether any chemical changes in the composition of the leaf had been caused by the substitution of double manure salts for high grade sulfate,

Table 32. Comparison of High Grade Sulfate with Double Manure Salts. Acre Yields for Six Years

\begin{tabular}{|c|c|c|c|c|c|c|c|c|c|}
\hline \multirow{2}{*}{$\begin{array}{l}\text { Source } \\
\text { of } \\
\text { potash }\end{array}$} & \multirow{2}{*}{$\begin{array}{l}\text { Plot } \\
\text { No. }\end{array}$} & \multicolumn{6}{|c|}{ Acre yield by years } & \multirow{2}{*}{$\begin{array}{l}\text { Plot } \\
\text { Ave. }\end{array}$} & \multirow{2}{*}{$\begin{array}{l}\text { Average } \\
12 \text { repli- } \\
\text { cations }\end{array}$} \\
\hline & & $1923 \mid$ & 1924 & 1925 & 1926 & 1927 & 1928 & & \\
\hline \multirow{2}{*}{$\begin{array}{l}\text { High grade } \\
\text { sulfate }\end{array}$} & K1 & 2056 & 1333 & 2054 & 1739 & 1223 & 1309 & 1619 & \multirow[b]{2}{*}{1630} \\
\hline & $\mathrm{K} 1-1$ & 2056 & 1387 & 2061 & 1832 & 1223 & 1280 & 1640 & \\
\hline \multirow{2}{*}{$\begin{array}{l}\text { Double man- } \\
\text { ure salts }\end{array}$} & K2 & 1966 & 1413 & 1932 & 1831 & 1355 & 1313 & 1635 & \multirow{2}{*}{1622} \\
\hline & K2-1 & 1966 & 1413 & 1892 & 1833 & 1234 & 1318 & 1609 & \\
\hline \multirow{2}{*}{$\begin{array}{l}\text { Half from } \\
\text { each }\end{array}$} & K3 & 2039 & 1467 & 2029 & 1712 & 1364 & 1341 & 1669 & \multirow{2}{*}{1638} \\
\hline & K3-1 & 2039 & 1333 & 1929 & 1648 & 1382 & 1378 & 1618 & \\
\hline
\end{tabular}

samples of seconds and darks for all plots (1926 crop) were analyzed. Since considerably more magnesia and sulfur are added to the soil in double manure salts, it was expected that a larger percentage of these elements would be found in the leaf. In view of the importance of potash in the burn, it seemed desirable to learn

Table 33. Comparison of High Grade Sulfate with Double Manure Salts. Grade Indexes for Five Years

\begin{tabular}{|c|c|c|c|c|c|c|c|c|}
\hline \multirow{2}{*}{$\begin{array}{l}\text { Source } \\
\text { of } \\
\text { potash }\end{array}$} & \multirow{2}{*}{$\begin{array}{l}\text { Plot } \\
\text { No. }\end{array}$} & \multicolumn{5}{|c|}{ Grade index by years } & \multirow{2}{*}{$\begin{array}{l}\text { Plot } \\
\text { Ave. }\end{array}$} & \multirow{2}{*}{$\begin{array}{l}\text { Average } \\
12 \\
\text { replications }\end{array}$} \\
\hline & & 1924 & 1925 & 1926 & 1927 & 1928 & & \\
\hline \multirow{2}{*}{$\begin{array}{l}\text { High grade } \\
\text { sulfate }\end{array}$} & $\mathrm{K} 1$ & .281 & .475 & .471 & .356 & .529 & .422 & \multirow{2}{*}{.436} \\
\hline & $\mathrm{K} 1-1$ & .291 & .475 & .505 & .457 & .516 & .449 & \\
\hline \multirow{2}{*}{$\begin{array}{c}\text { Double man- } \\
\text { ure salts }\end{array}$} & $\mathrm{K} 2$ & .281 & .476 & .479 & .468 & .517 & .444 & \multirow{2}{*}{.433} \\
\hline & $\mathrm{K} 2-1$ & .273 & .471 & .500 & .383 & .481 & .422 & \\
\hline \multirow{2}{*}{$\begin{array}{l}\text { Half from } \\
\text { each }\end{array}$} & $\mathrm{K} 3$ & .316 & .461 & .475 & .466 & .488 & .441 & \multirow{2}{*}{.425} \\
\hline & K3-1 & .270 & .483 & .461 & .357 & .472 & .409 & \\
\hline
\end{tabular}

whether the amount of potash absorbed had been affected. Since calcium and magnesium have a somewhat repressive effect on each other it was also decided to determine the percentage of calcium. These chemical analyses are summarized in Table 34. 
It is apparent that the use of double manure salts raised greatly the magnesia content of the leaves and correspondingly reduced the calcium. Both total sulfur and sulfate sulfur were increased and the percentage of potash absorbed was slightly lowered, especially in the seconds.

Table 34. Summary of Chemical Analyses of Tobacco from High Grade Sulfate and Double Sulfate Plots. Crop of 1926.

Averages of Duplicate Plots

\begin{tabular}{l|l|c|c|c|c|c|c}
\hline \hline \multirow{2}{*}{$\begin{array}{c}\text { Source } \\
\text { of } \\
\text { potash }\end{array}$} & \multirow{2}{*}{$\begin{array}{c}\text { Grade of } \\
\text { leaf }\end{array}$} & \multicolumn{5}{|c}{ Percentage in water free leaf } \\
\cline { 3 - 8 } & & $\begin{array}{c}\text { Potash } \\
\left(\mathrm{K}_{2} \mathrm{O}\right)\end{array}$ & $\begin{array}{c}\text { Total } \\
\text { Sulfur (S) }\end{array}$ & $\begin{array}{c}\text { Sulfate } \\
\text { sulfur (S) }\end{array}$ & $\begin{array}{c}\text { Lime } \\
(\mathrm{CaO})\end{array}$ & $\begin{array}{c}\text { Magnesia } \\
(\mathrm{MgO})\end{array}$ \\
\hline $\begin{array}{l}\text { High grade } \\
\text { sulfate }\end{array}$ & Darks & 7.23 & 0.84 & 0.72 & 5.81 & 1.17 \\
& Seconds & 8.07 & 0.72 & 0.58 & 6.84 & 1.41 \\
& Both & 7.65 & 0.78 & 0.65 & 6.32 & 1.29 \\
Double & & & & & & \\
manure & Darks & 7.05 & 1.00 & 0.87 & 4.76 & 1.97 \\
salts & Seconds & 7.54 & 0.81 & 0.69 & 5.94 & 2.28 \\
& Both & 7.30 & 0.90 & 0.78 & 5.35 & 2.13 \\
Half from & & & & & & \\
each & Darks & 6.98 & 0.86 & 0.73 & 5.84 & 1.49 \\
& Seconds & 7.33 & 0.70 & 0.59 & 6.88 & 1.64 \\
& Both & 7.16 & 0.78 & 0.66 & 6.36 & 1.56 \\
\hline
\end{tabular}

Effect on the burn. Since it is generally conceded that burn is roughly proportional to the potash which may form combinations with the organic acids after the mineral acids (sulfuric, hydrochloric, nitric, phosphoric) have been neutralized, it would be anticipated that the small increase in sulfate sulfur and the reduction in potash would be reflected in a corresponding reduction in fire-holding capacity. Strip burn tests on the fermented leaves from the crops of 1925,1926 , and 1927 disclosed that the average fire-holding capacity of all grades (total 480 tests from each treatment) for the three years was as follows:
High grade sulfate
Sulfate of potash-magnesia
41.2 seconds
One-half from each
36.6 "
38.7 “

The fire-holding capacity of each grade on all six plots was very high and the differences are probably too small to be significant. Comparing the three year averages, there appears to be a small but constant difference in favor of high grade sulfate, but it is questionable whether this difference is sufficiently large to offer serious objection to the use of double manure salts. 
Leaves from each plot were also made into cigars and smoked. The cigars from the double sulfate plots had a lighter colored ash and closer burn and were considered a little superior to the others. Fire-holding capacity of all was considered satisfactory.

Conclusions from the six year experiments. The original purpose of this experiment was to find whether any advantage would accrue from the substitution of sulfate of potash-magnesia ( 25 per cent $\mathrm{K}_{2} \mathrm{O}$ ) for high grade sulfate ( 48 per cent $\mathrm{K}_{2} \mathrm{O}$ ) as a source of potash in the tobacco mixture. At the end of six years we believe this question was answered for this particular type of soil as nearly as it can be answered by field and laboratory tests. Two of these years were excessively wet (conducive to sanddrown), one was excessively dry, one just a little too dry, and other two about optimum in rainfall.

When the records of the six years are averaged, the differences in yield and quality are found probably too small to be important. Offsetting a somewhat larger yield from the use of the combination of the two carriers, there is a slight advantage in grading and fire-holding capacity from the use of high grade sulfate. From the standpoint of yield, grading, and freedom from sand-drown, it may be stated definitely that there is no advantage in using double manure salts as the single carrier of potash. On this type of soil there has been no advantage in getting any of it from this material. In more sandy, "leachy" locations, however, it is conceivable that the use of 100 or 200 pounds of double sulfate per acre, might result in some advantage unless there are other sources of magnesia present. For the double purpose of preventing sanddrown and improving the ash characters, magnesian lime may be used to better advantage.

The disadvantages attending the use of double manure salts are (1) somewhat higher cost of the potash, (2) handling of a greater bulk of low grade material, (3) raising the sulfur content of the soil and leaf, (4) lowering the potash content, and (5) consequent reduction of fire-holding capacity as measured by the strip test. The advantages are (1) prevention of sand-drown and (2) making the ash whiter. The same advantages may be secured by using other carriers of. magnesia.

\section{Series IV. Tobacco Stems Compared with Mineral Carriers of Potash}

Although tobacco stems have been used more or less for many years by some growers, they have been applied in addition to other potash carriers and the potash which they contain has been discounted. In view of the fact that the potash in them is entirely water soluble and available for plant use during the first growing season, there would seem to be no good reason why this potash 
than stems. We may conclude from these experiments, therefore, that stems used alone will furnish all the potash needed and that their crop producing capacity is not exceeded by any of the mineral carriers. The cost of potash in stems is considerably higher than in mineral carriers, but the extra cost is at least partially offset by the value of the nitrogen, phosphorus, magnesia, and possibly other useful elements they contain. They also add organic matter to the soil. Whether these advantages are of sufficient weight to warrant the extra cost must be decided by the grower himself.

Chemical analyses of tobacco from the stems plots. It has been mentioned previously that growers have been accustomed to discount the value of potash in stems. Therefore, they think it necessary to add other potash carriers. In these stems plots, the same amount of potash to the acre was added as in adjacent plots where other carriers were used.

In order to see how much potash the crop actually absorbs from stems, as compared with other potash carriers, samples of fermented crops of 1928 and 1930 were analyzed. Results of the analyses, (Table 36) show that the crop takes at least as much potash from stems as it does from mineral sources.

Table 36. Percentage of Potash in Tobacco from Stems Plots

Compared with Tobacco Where Other Sources of

Potash Were Used

\begin{tabular}{|c|c|c|c|c|c|c|c|c|}
\hline \multirow{3}{*}{$\begin{array}{l}\text { Source } \\
\text { of } \\
\text { potash }\end{array}$} & \multirow{3}{*}{$\begin{array}{l}\text { Plnt } \\
\text { No. }\end{array}$} & \multicolumn{7}{|c|}{ Percentage potash in leaf (air dry basis) } \\
\hline & & \multicolumn{3}{|c|}{1928} & \multicolumn{3}{|c|}{1930} & \multirow{2}{*}{$\begin{array}{l}\text { Two } \\
\text { year } \\
\text { aver- } \\
\text { age }\end{array}$} \\
\hline & & Darks & $\begin{array}{l}\text { Sec- } \\
\text { onds }\end{array}$ & $\begin{array}{c}\text { Aver- } \\
\text { age }\end{array}$ & Darks & $\begin{array}{l}\text { Sec- } \\
\text { onds }\end{array}$ & $\begin{array}{l}\text { Aver- } \\
\text { age }\end{array}$ & \\
\hline \multirow{3}{*}{ Stems } & K14 & 7.42 & 9.72 & & 6.30 & 6.16 & & \\
\hline & $\mathrm{K} 14-1$ & 7.79 & 9.14 & 8.52 & 5.72 & 6.22 & 6.03 & 7.28 \\
\hline & K14-2 & & & & 5.85 & 5.91 & & \\
\hline \multirow{3}{*}{$\begin{array}{l}\text { Cottonhull } \\
\text { ashes }\end{array}$} & $\mathrm{K} 15-2$ & & & & 5.04 & 4.07 & 4.77 & \\
\hline & K15-1 & & & & 4.28 & 5.19 & & \\
\hline & K15-3 & & & & 4.57 & 5.44 & & \\
\hline \multirow{4}{*}{$\left.\begin{array}{l}\text { Sulfate } \\
\text { carbonate } \\
\text { and nitrate }\end{array}\right\}$} & K9-2 & & & & 6.01 & 6.06 & & \\
\hline & K9-3 & & & & 6.32 & 5.72 & 5.96 & 6.96 \\
\hline & K9-4 & & & & 5.37 & 6.26 & & \\
\hline & K9-5 & 7.30 & 8.64 & 7.97 & & & & \\
\hline
\end{tabular}

Effect on burning quality. Tobacco of four grades of each of the stems plots for the years 1928 and 1930 was tested by the usual strip test-20 for each grade of each plot. This was compared with three plots where all mineral potash was used and, in 1930, 
with four plots where cottonhull ashes were used for potash. All of these were in the same series and otherwise treated alike. The results, recorded in Tables 29 and 37, show that the burn on the stems plots was as good as any of the others. Cigars were also made from each and tested, but no significant differences were observed in burn, taste or aroma.

Table 37. Stems and Cottonhull Ashes Compared with Potash from Sulfate, Carbonate and Nitrate of Potash. Strip Burn Tests OF 1930 CROP

\begin{tabular}{|c|c|c|c|c|c|c|c|}
\hline \multirow{2}{*}{$\begin{array}{l}\text { Source of } \\
\text { potash }\end{array}$} & \multirow{2}{*}{ Plot No. } & \multicolumn{4}{|c|}{ Duration of burn by grades } & \multicolumn{2}{|c|}{ Average } \\
\hline & & Darks & Mediums & Lights & Seconds & Plot & Treatment \\
\hline \multirow{3}{*}{ Stems } & K14 & 42 & 46 & 47 & 55 & 47 & \multirow{3}{*}{50.0} \\
\hline & $\mathrm{K} 14-1$ & 43 & - & 58 & 56 & 52 & \\
\hline & $\mathrm{K} 14-2$ & 45 & 54 & 50 & 57 & 51 & \\
\hline \multirow{3}{*}{$\begin{array}{l}\text { Sulfate, } \\
\text { carbonate, } \\
\text { and nitrate }\end{array}$} & K9-2 & 47 & 39 & 50 & 44 & 45 & \multirow{3}{*}{49.3} \\
\hline & K9-3 & 45 & 51 & 50 & 46 & 48 & \\
\hline & $\mathrm{K} 9-4$ & 48 & 56 & 59 & 56 & 55 & \\
\hline \multirow{4}{*}{$\begin{array}{l}\text { Cottonhull } \\
\text { ashes }\end{array}$} & $\mathrm{K} 15-1$ & 39 & 28 & - & 26 & 31 & \multirow{4}{*}{33.0} \\
\hline & K15-3 & 46 & 16 & 14 & 16 & 31 & \\
\hline & $\mathrm{K} 15-2$ & 45 & 29 & 37 & 29 & 35 & \\
\hline & K15-4 & 35 & - & 41 & 32 & 36 & \\
\hline
\end{tabular}

\section{Series V. Comparison of Cottonhull Ashes with Other Materials}

Thirty to forty years ago, ash made by the burning of cottonseed hulls in the South was a commonly used source of potash for tobacco in New England. These ashes contained a variable percentage (15 to 35 per cent) of potash in the form of carbonate, carbonates of calcium and magnesium, and some phosphoric acid, as well as small amounts of other elements, some of which may be important in plant growth. Later, the use of cottonhull ashes was discontinued, but within the last six years this material has again appeared on the market and has been used with success by many growers.

Chemical analyses of 14 samples taken at random from those submitted to the Station by growers in 1930 are given in Table 38 . The percentege of chlorine, which varies in these samples from .43 to 2.33 per cent, is probably not sufficient to affect seriously the burn of the tobacco. 
Tarle 38. Chemical Analyses of Samples of Cotton hull Ashes Sold FOR TOBACCO IN 1930

\begin{tabular}{l|r|r|r|r|r|r|r|}
\hline \hline \multirow{2}{*}{$\begin{array}{l}\text { No. of } \\
\text { sample }\end{array}$} & \multicolumn{6}{|c|}{ Percentage } & \multirow{2}{*}{ Water } \\
\cline { 2 - 7 } & $\mathrm{K}_{2} \mathrm{O}$ & $\mathrm{P}_{2} \mathrm{O}_{5}$ & $\mathrm{CaO}$ & $\mathrm{MgO}$ & $\mathrm{Cl}$ & Boron $\left(\mathrm{B}_{2} \mathrm{O}_{3}\right)$ & \\
\hline 3601 & 31.67 & 2.15 & 10.67 & 4.35 & 2.33 & 0.029 & \\
3667 & 23.35 & 2.90 & 12.52 & 4.38 & 1.34 & 0.024 & \\
3668 & 24.60 & 2.80 & 11.41 & 5.17 & 1.45 & 0.022 & \\
3669 & 24.79 & 2.78 & 11.47 & 4.99 & 1.47 & 0.035 & \\
3693 & 22.95 & 3.07 & 10.38 & 5.05 & 1.39 & 0.022 & \\
3694 & 23.64 & 2.86 & 10.15 & 4.48 & 1.59 & 0.024 & \\
3753 & 25.27 & 3.71 & 8.33 & 3.93 & 0.94 & 0.021 & \\
3786 & 29.97 & 2.72 & 8.50 & 3.97 & 1.97 & 0.029 & \\
3818 & 29.07 & 2.65 & 9.16 & 3.93 & 2.15 & 0.036 & \\
3826 & 23.03 & 2.33 & 15.35 & 5.64 & 0.87 & 0.008 & \\
3827 & 33.57 & 1.88 & 12.62 & 3.94 & 1.84 & 0.011 & \\
3949 & 20.97 & 3.18 & 19.94 & 8.14 & 0.43 & 0.011 & \\
3990 & 38.17 & 2.80 & 14.10 & 4.93 & 1.76 & 0.003 & \\
4026 & 25.31 & 5.00 & 12.73 & 5.35 & 0.83 & 0.009 & \\
& & & & & & & \multirow{2}{*}{ App. 9.00-10.00 } \\
Average & 26.88 & 2.92 & 11.95 & 4.87 & 1.45 & 0.020 & \\
\hline
\end{tabular}

In order to compare cottonhull ashes with other sources of potash, five plots were added in 1929 to those described above in Series II on Field I. The formula used was as follows:

Cottonseed meal, 1765 lbs. Castor pomace, $7+1 \mathrm{lbs}$. Nitrate of soda, 260 lbs. Cottonhull ashes, 590 lbs.

Total

\begin{tabular}{cccc}
\hline & \multicolumn{2}{c}{ Nutrients per acre } & \\
\cline { 4 - 4 } Nitrogen & $\begin{array}{c}\text { Phosphoric } \\
\text { acid }\end{array}$ & Potash & Magnesia \\
120 & 52.9 & 35.3 & 12.4 \\
40 & 14.8 & 7.4 & 5.9 \\
40 & & 157.3 & 30.4 \\
& 17.7 & & \\
\hline 200 & 85.4 & 200 & 48.7
\end{tabular}

This supplied the same quantity of the nutrient elements as was applied to the adjacent plots. The tobacco was destroyed by hail in 1929 and no results were computed. The experiment was repeated in 1930 and 1931 on the same plots.

Because of lack of sufficient land, four of the plots were end plots and although two to six rows of tobacco were discarded on each extreme end before harvesting, there is still the possibility that the poor showing made by these plots may have been partly due to their unfavorable location. K15-1 was the only interior plot. The yield and grade indexes compared with the average for the other carriers are presented in Table 39. If the averages of the five cottonhull ash plots are compared with the averages for the other 
potash carriers, the comparison is very unfavorable, both in yield and grading, to the cottonhull ashes plots. If, however, we assume that the end plots were not comparable and consider only the K15-1 plot, which was as favorably located as the others, we find it has an average yield of 1855 , about the same as for the other sources of potash, and an index of .434 , which is somewhat lower than any of the others.

Table 39. Cottonhull Ash Plots; Yield and Grade Indexes Compared with Plots Where Other Sources of Potash Were Used

\begin{tabular}{l|c|c|c|c|c|c|c}
\hline \multirow{2}{*}{ Potash carrier } & \multirow{2}{*}{ Plot No. } & \multicolumn{3}{|c|}{ Yield } & \multicolumn{3}{|c}{ Grade index } \\
\cline { 3 - 7 } & & 1930 & 1931 & Average & 1930 & 1931 & Average \\
\hline \multirow{3}{*}{ Cottonhull ash } & K15 & 1798 & 1661 & & .400 & .385 & \\
& K15-1 & 1809 & 1901 & & .456 & .411 & \\
& K15-2 & 1803 & 1775 & 1710 & .466 & .430 & .400 \\
& K15-3 & 1562 & 1709 & & .327 & .396 & \\
Sulfate & K15-4 & 1494 & 1589 & & .368 & .360 & \\
Carbonate & & & & & & & \\
Nitrate & All plots & 1910 & 1793 & 1852 & .455 & .453 & .454 \\
Stems & of this & 1884 & 1813 & 1849 & .471 & .456 & .464 \\
& series & 1941 & 1835 & 1888 & .464 & .451 & .458 \\
& & 1977 & 1940 & 1959 & .466 & .460 & .463 \\
\hline
\end{tabular}

A formula advocated and successfully used by many growers is one composed only of cottonseed meal and cottonhull ashes. In order to see whether this would produce better yield or quality, two plots in the center of the field were treated in 1931 with such a formula, as follows:

\section{Cottonseed meal $\quad 3000 \mathrm{lbs}$. Cottonhull ashes $\quad 441$ lbs.}

This formula supplied 200 pounds nitrogen, 200 pounds potash, 103 pounds phosphoric acid, and 43 pounds magnesia, and was therefore considered a well balanced formula, comparable to the others on the same field. These plots were well located with reference to the others and on land that had previously produced as much and as good tobacco as the others. The results for 1931, the first year of the experiment, are summarized in Table 40. Here, under the most favorable conditions, the average yield and grade index of these plots are both below those of any of the other sources of potash. 
The results do not indicate that cottonhull ashes are a more favorable source of potash than the other carriers. Since the form in which the potash occurs here is mostly carbonate of potash, it is probable that more favorable results that might be expected would come from the other elements in the ash. In view of our results with magnesia $(7: 391)$, it seems likely that the quantity of this element in cottonhull ashes would have a favorable effect on the burn.

The tobacco from the cottonhull ashes plots of 1930, were tested by the strip test and showed a shorter duration of burn than that from the other plots. It is quite possible that this may be due to decreased percentage of potassium (as shown in Table 36) and increased content of magnesium, which might be expected in tobacco from the cottonhull ashes plots. As we have previously written $(7: 391)$, this does not necessarily indicate an inferior burn when tested on the cigar.

Table 40. Special Cottonhull Ash and Cottonseed Meal Plots. Yield ANd Grade INdexes For 1931

\begin{tabular}{l|c|c|c|c|c}
\hline \hline \multirow{2}{*}{ Potash source } & \multirow{2}{*}{ Plot No. } & \multicolumn{2}{|c|}{ Yield } & \multicolumn{2}{c}{ Grade index } \\
\cline { 3 - 6 } & & Plot & Average & Plot & Average \\
\hline Cottonhull ash & K16 & 1762 & 1781 & .450 & .444 \\
Cottonseed meal & K16-1 & 1800 & & .447 \\
& & & & & \\
Sulfate & Average of & & 1793 & & .453 \\
Carbonate & all plots & & 1813 & & .456 \\
Nitrate & in Series & & 1835 & & .451 \\
Stems & II. & & 1940 & & .460 \\
\hline
\end{tabular}

Through the courtesy of one of the large cigar manufacturing corporations, the writers compared the smoking quality of cigars from tobacco raised on a cottonhull ash formula with an equal number of others from tobacco raised on the same 12 fields, in various parts of the Connecticut Valley, but with other sources of potash (standard commercial fertilizer mixtures). Neither the writers nor the experts from the manufacturing company could detect any consistently favorable influence on the burn, taste or aroma of the cottonhull ash cigars as compared with the others.

Final conclusions as to the relative value of cottonhull ashes and other potash carriers must await the continuation of these experiments through a longer series of years. Nothing in the results at present indicates that this material is in any way superior to the others. 


\section{SUMMARY}

1. Tobacco as compared with other crops is a heavy feeder on potash, removing annually from the soil about 150 pounds.

2. Potash functions in all plants as a catalyst in the synthesis of carbohydrates and probably proteins and in the absorption and translocation of nutrient materials. Also it makes the plants more resistant to drought and possibly to certain types of diseases.

In tobacco, it has the added functions of (1) making the cured leaves soft and suitable for handling and (2) promoting the incandescent type of combustion required for cigars.

3. Tobacco plants that have not enough potash for their physiological needs show characteristic starvation symptoms, the most prominent of which are yellow mottling, dead specks, "hobbly" surface, and downward incurving of margins and tips.

4. The amount of potash in the leaf is not a fixed percentage, but differs widely, depending on (1) the quantity in the soil, (2) relation of other bases in the soil, and (3) weather conditions.

This percentage varies directly with the potash applied in the fertilizer, and inversely with the proportion of calcium and magnesium. The quantity of potash is generally higher in wet seasons than in dry.

5. The tobacco soils of Connecticut have a large supply of native potash in minerals derived from the parent rocks. This potash is not readily available to the crop. A very small percentage becomes available each year, but it is far from sufficient to meet the requirements of the tobacco crop; therefore, annual applications of potassic fertilizers are necessary.

6. Certain agricultural practices may accelerate the liberation of the native potash, but none of them alone or in combination can be relied on to furnish sufficient potash for crop needs. Materials that may have some accelerating effect are gypsum, nitrate of soda, sulfur, manure, and fertilizers that increase acidity of the soil. Turning under cover crops is also beneficial in this respect.

7. Considerable quantities of potash (40-130 pounds) are lost from tobacco soils annually in the drainage water. Only a small part of this loss occurs while the tobacco is in the field.

The loss in lysimeter tanks containing only the surface 7 inches of soil, varied with soil type, being lowest on a soil of high colloid content (12-38 pounds) and higher on sandier soils (72 pounds). Among nitrogeneous fertilizers, sulfate of ammonia greatly increased the outgo, while nitrate of soda had the opposite effect. A distinct correlation between water loss and leaching of potash was noted on the sandier soils. 
No differences due to treatment were reflected in the potash loss for the first year from the 20 -inch tanks. During the second year the effects of sulfate of ammonia and nitrate of soda noted above became more evident, while the effect of a huge excess of potash in nitrate of potash also began to be apparent. Where organic fertilizers were used, there were no significant differences in outgo.

8. In the plant, potassium exists only in soluble ionizable compounds, never in organic combination with the protoplasm or other essential parts. All potash may be removed from the cured leaves by leaching with cold water.

It is the hygroscopicity of these potash compounds that makes cured tobacco come into "case" during damp weather.

9. A study of the rate of potash absorption in the field showed that, exclusive of the seedling stage, no consistent trend toward increase or decrease in percentage in the plant occurred during the growing season. When the percentage of potash in the plant was high, nitrogen also was found to be high for the same period, thus indicating a parallel absorption. Maximum potash absorption, in terms of pounds per acre, occurred during the fifth and seventh weeks of field growth, the same periods that showed the greatest increases in dry weight and total nitrogen.

10. Fire-holding capacity of cured leaves is dependent on the potash salts contained. The different salts of potassium are not equally suitable for imparting fire-holding capacity. In the order of their excellence, those tested rank as follows: carbonate, malate, citrate, oxalate, acetate, nitrate, hydrate, sulfate, secondary phosphate, chloride and primary phosphate. In general, the organic salts were most effective. The inorganic salts impart at most only a small degree of fire-holding capacity.

11. Increase in the amount of potash in the leaf makes the ash darker in color.

12. The annual application of potash should be about 200 pounds per acre to produce the best results under such conditions as those on the fields of the Tobacco Substation.

13. Reduction in the fertilizer potash affects the quality more than the quantity of the crop. Only at our lowest rate (40 pounds per acre) was there a reduction in yield, and this was not apparent the first year. In quality, however, the leaves with insufficient potash were quite inferior, being harsh, dry, short, and non-elastic.

14. Chemical analyses of the leaves show that with every decrease of fertilizer potash there is a corresponding reduction in the percentage of potash in the leaf, and at the same time an increase in the calcium and magnesium. 
15. Each decrease in potash is also accompanied by a reduction in the fire-holding capacity as measured by the strip test. In the same degree, the ash becomes whiter.

16. Six carriers of potash-sulfate, carbonate, nitrate, sulfate of potash-magnesia, stems and cottonhull ashes-were compared on field plots through a series of years. As far as yield of leaf and percentages of grades are concerned, the differences have been very small. Somewhat the best results have been obtained with stems.

17. Potash in all these carriers is fully available. Potash in stems should be rated at its full value in preparing the fertilizer formula.

18. Chemical analyses do not show a greater quantity of potash absorbed by the plant from one carrier than from another, except materials containing repressive amounts of magnesium.

19. Fire-holding capacity of leaves grown on these different carriers, as determined by the strip test, is about the same, except for cottonhull ashes, which is somewhat lower. Cigars made from leaves grown with the use of each of these carriers all have a satisfactory burn.

20. None of these carriers produces any significant change in soil reaction when used in sufficient amount to supply 200 pounds of potash to the acre.

21. In short, each of these six carriers appears to be satisfactory for use in a tobacco mixture. It is suggested, however, that the grower furnish the potash in two or more carriers, rather than one. 


\section{LITERATURE CITED}

1. Ames, J. W., and G. E. Boltz. Influence of fertilizers on composition and quality of tobacco. Ohio Agr. Expt. Sta., Bul. 285: 173-221. 1915.

2. Anderson, P. J., and otmers. Report of the tobacco station at Windsor for 1925. Conn. Agr. Expt. Sta., Tob. Subst. Bul. 6: 1-93. 1926.

3. Anderson, P. J., and N. T. Nelson. Report of the tobacco station at Windsor for 1926. Conn. Agr. Expt. Sta., Tob. Subst. Bul. 8: 1-58. 1927.

4. Anderson, P. J., N. T. Nelson and T. R. Swanback. Report of the tobacco station at Windsor for 1927. Conn. Agr. Expt. Sta., Tob. Subst. Bul. 10: 1-82. 1928.

5. Anderson, P. J., and T. R. Swanback. Report of the tobacco substation at Windsor for 1928. Conn. Agr. Expt. Sta., Bul, 299: 145-203. 1929.

6. Anderson, P. J., T. R. Swanback, O. E. Street and others. Tobacco substation at Windsor, report for 1929. Conn. Agr. Expt. Sta., Bul. 311: 207-273. 1930 .

7. Anderson, P. J., T. R. Swanback, O. E. Street, and others. Tobacco substation at Windsor, report for 1930. Conn. Agr. Expt. Sta., Bul. 326: 357-450. 1931.

8. Ballentine, W. Experiments with feldspar as a source of potash. Maine Agr. Expt. Sta., Ann. Rpt. for 1889: 135-144. 1890.

9. BARTh, MAX. Untersuchungen von im Elsass gezogenen Tabaken und einige Beziehungen zwischen der Qualität des Tabaks und seiner Zusammensetzung. Landw. Vers. Sta., 39: 81-104. 1891.

10. Bartholomew, R. P. The availability of potassium to plants, as affected by barnyard manure. Jour. Amer. Soc. Agron., 20: 55-81. 1928.

11. Bartholomew, R. P., and G. Jannsen. Luxury consumption of potassium by plants and its significance. Jour. Amer. Soc. Agron., 21 : 751-765. 1929.

12. Bartholomew, R. P., and G. Jannsen. The rate of absorption of potassium by plants and its possible effect upon the amount of potassium remaining in soils from applications of potassium fertilizers. Ark. Agr. Expt. Sta., Bul. 265 : 1-70. 1931.

13. Behrens, J. Weitere Beiträge zur Kenntniss der Tabakpflanze. V. Der anatomische Bau und die Bestandteile des Tabakblattes in ihrer Beziehung zur Brennbarkeit. Landw. Vers. Sta., 43: 271-301. 1894.

14. Behrens, J. Weitere Beiträge zur Kenntniss der Tabakpflanze. Landw. Vers. Sta., 41: 191-206. 1892.

15. Bemmelen, J. M. van. Über die Zusammensetzung der Asche der Tabakblätter in Beziehung zu ihrer guten oder schlechten Qualität insbesondere zu ihrer Brennbarkeit. Landw. Vers. Sta., 37: 405-436. 1890.

16. Bцот. Determination des époques ou le tabac vert contient le maximum de potasse aux acides organiques et le minimum de nicotine. Memorial des Manufactures de l'état. Tabacs I. Livr: I. Paris. 1884.

17. Boening, K. Die Wildfeuerkrankheit des Tabaks. Flugbl. 55. Bayer Landesanstalt f. Pflanzenbau u. Pflanzenschutz. Munich. 1929.

18. Bradley, C. E. The soils of Oregon. Oreg. Agr. Expt. Sta., Bul. 112. 1912. 
19. Briggs, L. J., and J. F. Breazeale. Availability of potash in certain orthoclase-bearing rocks as affected by lime and gypsum. Jour. Agr. Res., 8: 21-28. 1917.

20. Collison, S. E., and S. S. Walker Loss of fertilizers by leaching. Fla. Agr. Expt. Sta., Bul. 132: 1-20. 1916.

21. Crawley, J. T., and W. B. Cody. The application of fertilizers to the soil and losses by leaching. Porto Rico Bd. Agr. Expt. Sta., Bul. 8: 17-23. 1915. Abstract in E. S. R. 33: 122.

22. Cserhati, A. Versuche über die Brennbarkeit des Tabaks. Jour. Landw., $43: 379-458.1895$.

23. Cubbon, M. H. Calcium sulfate as a soil amendment. N. Y. (Cornel1) Agr. Expt. Sta., Mem. 97 : 1-51. 1926.

24. Cushman, A. S. The use of phosphatic rocks as fertilizers. U. S. D. A. Bur. P1. Indus., Bu1. 104 : 1-31. 1907.

25. Davidson, R. J. Analyses of parts of tobacco plants at different stages of growth. Va. Agr. Expt. Sta., Bul. 50 (new ser.) : 25-52. 1895.

26. DeTurk, E. Potassium-bearing minerals as a source of potassium for plant growth. Soil Sci., 8: 269-301. 1919.

27. Fesca, M. (In collaboration with H. IMAI.) Ueber Kultur, Behandlung und Zusammensetzung Japanischer Tabake. Landw. Jahrb., 17: 329-372. 1888. (Berlin)

28. Fonder, John F. Variations in potassium content of alfalfa due to stage of growth and soil type and the relationship of potassium and calcium in plants grown upon different soil types. Jour. Amer. Soc. Agron., 21: 732-750. 1929.

29. Fraps, G. S. Relation of the water-soluble potash, the replaceable, and acid-soluble potash to the potash removed by crops in pot experiments. Tex. Agr. Expt. Sta., Bul. 391: 1-18. 1929.

30. FudGe, J. F. The influence of various nitrogenous fertilizers on the availability of phosphate and potassium. Ala. Agr. Expt. Sta., Bul. 227 : 1-47. 1928.

31. Gaither, E. W. The effect of lime upon the solubility of the soil constituents. Jour. Indus. and Engin. Chem., 2: 315. 1910.

32. Garner, W. W. The relation of the composition of the leaf to the burning qualities of tobacco. U. S. Dept. Agr. Bur. Plant Indus., Bul. 105: 27.1907.

33. Garner, W. W., and D. E. Brown. Fertilizer experiments with tobacco. Md. Agr. Expt. Sta., Bul. 225 : 157-183. 1919.

34. Gerlach, M. The action of kainit and high-percentage potash salts. Fuhling's Landw. Ztg., 50:377-388, 409-416. 1901. Abs. in E. S. R. 13: 539 .

35. Graham, DeV., and R. H. Carr. Chemical factors determining the quality of tobacco. Jour. Amer. Chem. Soc., 46: 695-702. 1924.

36. Haley, D. E., E. S. Nasset, and Otto Olson. A study of certain constituents of the leaf and their relation to the burning qualities of tobacco. Plant Physiol., 3 : 185-197. 1928.

37. HALL, A. D. Fertilizers and manures. 3d ed. John Murray, London. 1929. 
38. Headden, Wm. P. The carbon dioxide in the soil atmosphere and its action on the feldspar particles in the soil. Colo. Agr. Expt. Sta., Bul. 319. 1927.

39. Hendrick, J., and H. D. Welch. The substances removed by the drainage from a scottish soil. Proc. and Papers 1st Internatl. Cong. of Soil Sci., 2 : 358-366. 1927.

40. Hopkins, Cyril G. Soil fertility and permanent agriculture. Ginn and Co. 1910.

41. Hopkins, Cyril G., and J. P. Aumer. Potassium from the soil. Ill. Agr. Expt. Sta., Bul. 182. 1915.

42. Kostytschew, S., and P. Eliasberg. Ueber die Form des Kaliumverbindungen in lebenden Pflanzengeweben. Zeitsch. f. Phys. Chemie 111: 228-235. 1920.

43. KRAYbiLi, H. R. Effect of some alkali salts upon fire-holding capacity of tobacco. Bot. Gaz., 64: 42-56. 1917.

44. Lagatu, H., and L. Maume. Antagonisme du calcaire, a l'égard de l'absorption de la potasse par la vigne. Com. Cong. Internatl. du vin et du pin maritime. Bordeaux. 1928.

45. Lipman, J. G., A. W. Blair, and A. L. Prince. The effect of lime and fertilizers on the potash content of soils and crops. Internatl. Rev. Sci. and Pract. Agr., 4: 546-553. 1926.

46. Lyon, T. L., and J. A. Bizzell. Lysimeter experiments. New York (Cornell) Agr. Expt. Sta., Memoir 12. 1918.

47. Lyon, T. L., and J. A. Bizzell. Lysimeter experiments. New York (Cornell) Agr. Expt. Sta., Memoir 41. 1921.

48. MacIntire, W. H. The influence of fertilizers upon the composition of wheat. Penn. State Col. Ann. Rpt. 1910-11: 190. 1911.

49. Macintire, W. H., and K. B. Sanders. The fixation of the potash of a green manure by liming materials. Soil Sci., 29: 109-117. 1930.

50. Macintire, W. H., W. M. Shaw, and J. B. Young. A five-year lysimeter study of the supposed liberation of soil potassium by calcic and magnesic additions. Soil Sci., 16: 217-223. 1923.

51. Macintire, W. H., W. M. Shaw, and K. B. Sanders. The influence of liming on the availability of soil potash. Jour. Amer. Soc. Agron., 19: 483-504. 1927.

52. Macintire, W. H., W. M. Shaw, and J. B. Young. The repressive effect of lime and magnesia upon soil and subsoil potash. Jour. Agr. Sci., 20 : 499-509. 1930.

53. Mathewson, E. H. The burning quality of tobacco with suggestions for its improvement in the flue-cured types of eastern North Carolina. Bur. Plant Indus. Circ. issued Nov. 19, 1910.

54. Mayer, Adolf Eduard. Über die Verbrennlichkeit des Tabaks. Landw. Vers. Sta., 38: 127-139. 1891.

55. McCallum, A. B. On the distribution of potassium in animal and vegetable cells. Jour. Physiol., 32: 95-128. 1905. (British)

56. McCool, M. M., and M. D. Weldon. The effect of soil type and fertilization on the composition of the expressed sap of plants. Jour. Amer. Soc. Agron., 20: 778-792. 1928.

57. Morgan, M. F. The soils of Connecticut. Conn. Agr. Expt. Sta., Bul. 320. 1930. 
58. Morgan, M. F., P. J. Anderson, and Henry Dorsey. Soil reaction and liming as factors in tobacco production in Connecticut. Conn. Agr. Expt. Sta., Bul. 306: 773-806. 1929.

59. Morgan, M. F., O. E. Street, and H. G. M. Jacobson. Fertilizer losses through leaching as measured by lysimeter experiments. Conn. Agr. Expt. Sta., Bul. 326 : 432-441. 1931.

60. Moss, E. G., J. E. McMurtrey, W. M. Lunn, and J. M. Carr. Fertilizer tests with flue-cured tobacco. U. S. Dept. of Agr., Tech. Bul. 12. 1927.

61. Nelson, N. T., and P. J. Anderson. Fertilizer experiments with tobacco. Conn. Agr. Expt. Sta., Tob. Sta. Bul. 5 : 1-34. 1925.

62. Nessler, J. Der Tabak seine Bestandtheile und seine Behandlungen. Mannheim. 1867.

63. Nessler, J. Über die Wirkung des Bodens und der Düngung auf die Verbrennlichkeit des Tabaks. Biedermann's Zentbl., 18: 488-494. 1889. (Abs.)

64. Nessler, J. Über den Bau und die Behandlung des Tabaks. Landw. Vers. Sta., $40:$ 395-438. 1892.

65. Otryganjew, A. W. Experiments with different forms and quantities of nitrogen and potassium fertilizers. Krasnodar (Russia) Tob. Expt. Sta., Bul. 28: 60-62. 1926.

66. Patterson, H. J. The effects of different fertilizing elements on the composition and combustibility of tobacco. Agr. Sci., 8: 329-352. 1894. (Reprint.)

67. Prianischnikov, D. Vegetationsversuche mit verschiedenen kalihaltigen Mineralien. Land. Vers. Sta., 77 : 399. 1912.

68. Quajat, E. Untersuchung über die Verbrennlichkeit einiger Tabakssorten. Biedermann's Zentbl., 9: 345-347. 1880. (Abs.)

69. REed, H. S., and A. R. C. HAAs. Studies on the effects of sodium, potassium and calcium on young orange trees. Calif. Agr. Expt. Sta., Tech. Paper 11:1-23. 1923.

70. Sayre, C. B., J. J. Willaman, and Z. I. Kertesz. Factors affecting the quality of commercial canning peas. N. Y. (Geneva) Agr. Expt. Sta., Tech. Bul. 176: 1-75. 1931.

71. Schloesing, Тн. Über die Verbrennlichkeit des Tabaks. Jour. Prakt. Chem., 81: 143-150. 1860.

72. Sewell, M. C., and W. L. Latshaw. The effect of lime, superphosphate and potash on reaction of soil and growth and composition of alfalfa. Jour. Amer. Soc. Agron., 23: 799-814. 1931.

73. SHEDd, O. M. Influence of sulfur and gypsum on the solubility of potassium in soils and on the quantity of this element removed by certain plants. Soil Sci., 22: 335-354. 1926.

74. Sligh, T. S. Jr., and Henry R. Kraybill. Temperature of a burning cigar. Bul. Amer. Inst. Mining \& Metall. Engin. 1919: 2241-2246.

75. TRESSLER, D. K. The solubility of soil potash in various salt solutions. Soil Sci., 6: 237-257. 1918.

76. Vedroedr, VikToR. Eine Studie über die Verbrennlichkeit des Tabaks. Landw. Vers. Sta., 45: 295-310. 1895.

77. Vickery, H. B., and G. W. Pucher. A preliminary study of the nonvolatile organic acids of tobacco leaves. Conn. Agr. Expt. Sta., Bul. 323 : 155-202. 1931. 






\section{Univesily of Connecticut Libraries}

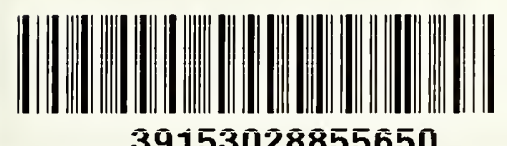


